
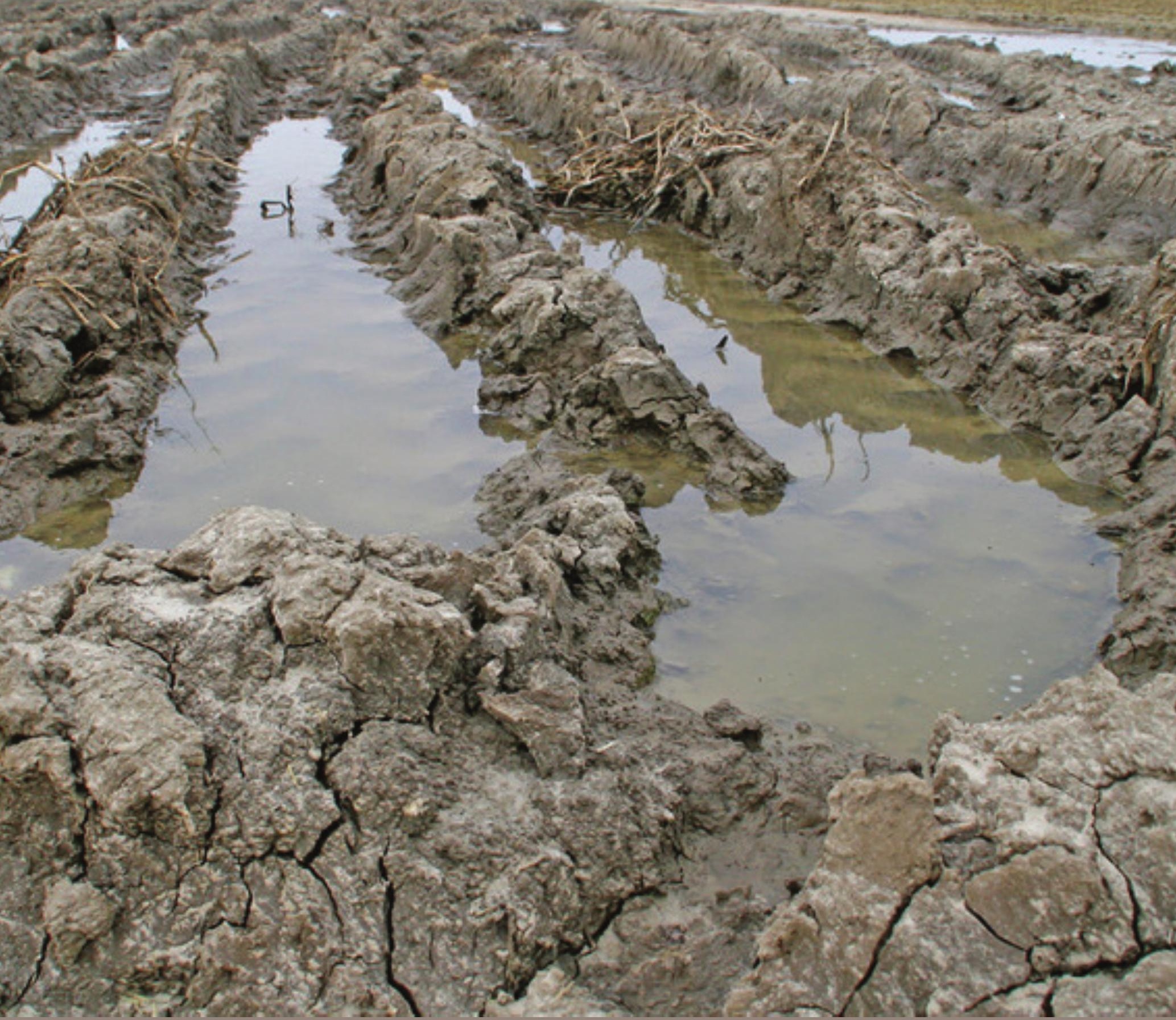

\title{
Bodemhydrofysische gegevens in BRO en BIS - Update 2016
}





\section{Bodemhydrofysische gegevens in BRO en BIS - Update 2016}

G. Bakker, M. Heinen, J.G. Wesseling, W.J.M. de Groot, F.B.T. Assinck, E.W.J. Hummelink

Dit onderzoek is uitgevoerd door Alterra Wageningen UR in opdracht van en gefinancierd door het ministerie van Economische Zaken, in het kader van het Beleidsondersteunend onderzoekthema 'BIS' (projectnummers 2012-2014: BO-11-017-012 en 2016: BO-11-017-026).

Wageningen Environmental Research

Wageningen, februari 2017

Rapport 2789

ISSN 1566-7197 
Bakker, G., M. Heinen, J.G. Wesseling, W.J.M. de Groot, F.B.T. Assinck, E.W.J. Hummelink, 2017. Bodemhydrofysische gegevens in BRO en BIS - Update 2016. Wageningen, Wageningen Environmental Research, Rapport 2789. 78 blz.; 8 fig.; 12 tab.; 81 ref.

Bodemhydrofysische (BhF) gegevens, zoals de waterretentie- en doorlatendheidskarakteristiek, organische stofgehalte, textuurgegevens, profielbeschrijving en andere metagegevens zijn belangrijke basisgegevens bij het modelleren van transport van water en opgeloste stoffen in de onverzadigde zone, maar vinden ook tal van andere toepassingen. Omdat er grote behoefte is aan actuele BhFgegevens van hoge kwaliteit en omdat de huidige databases onvoldoende opschalingsmogelijkheden bieden, zijn in dit project in 2012-1016 118 nieuwe bodemhydrofysische gegevens van goede kwaliteit gegenereerd. De BhF-gegevens en de bijbehorende beschrijvende gegevens zijn ondergebracht in het BIS (Bodem Informatie Systeem). Aanvullend zijn reeds bestaande Priapus-gegevens van hoge kwaliteit ondergebracht in BIS, onder te verdelen in twee categorieën: 1) van 44 bestaande monsters zijn beschikbare gegevens ondergebracht in BIS en zijn gekoppeld aan bestaande BISprofielbeschrijvingen en 2) afgeleide gegevens met onvoldoende kwaliteit van 10 Priapus-monsters zijn met verbeterde software opnieuw doorgerekend en na herkeuring alsnog goed bevonden en tezamen met bestaande profielbeschrijvingen in BIS opgenomen. Tot slot is er van 53 oude Priapusmonsters met hoge kwaliteit een koppeling op papier gelegd met beschrijvende gegevens in de literatuur, zodat er in totaal fysiek 172 monsters in BIS zijn ondergebracht en in potentie nog eens 53.

Trefwoorden: Bodemfysica, bodemhydrofysica, bodemfysische meetgegevens, BIS, BRO, retentiecurve, pF-curve, waterdoorlatendheid

Dit rapport is gratis te downloaden van http://dx.doi.org/10.18174/408308 of op www.wur.nl/environmental-research (ga naar 'Wageningen Environmental Research' in de grijze balk onderaan). Wageningen Environmental Research verstrekt geen gedrukte exemplaren van rapporten.

2017 Wageningen Environmental Research (instituut binnen de rechtspersoon Stichting Wageningen Research), Postbus 47, 6700 AA Wageningen, T 03174807 00, E info.alterra@wur.nl, www.wur.nl/environmental-research. Wageningen Environmental Research is onderdeel van Wageningen University \& Research.

- Overname, verveelvoudiging of openbaarmaking van deze uitgave is toegestaan mits met duidelijke bronvermelding.

- Overname, verveelvoudiging of openbaarmaking is niet toegestaan voor commerciële doeleinden en/of geldelijk gewin.

- Overname, verveelvoudiging of openbaarmaking is niet toegestaan voor die gedeelten van deze uitgave waarvan duidelijk is dat de auteursrechten liggen bij derden en/of zijn voorbehouden.

Wageningen Environmental Research aanvaardt geen aansprakelijkheid voor eventuele schade voortvloeiend uit het gebruik van de resultaten van dit onderzoek of de toepassing van de adviezen.

Wageningen Environmental Research Rapport 2789 | ISSN 1566-7197

Foto omslag: www.akkerwijzer.nl 


\section{Inhoud}

Woord vooraf $\quad 5$

$\begin{array}{ll}\text { Samenvatting } & 7\end{array}$

1.1 Nut en noodzaak van bodemhydrofysische gegevens 9

1.1.1 Bodemhydrofysische gegevens als basis 9

1.1.2 Gezonde bodems (Eng: healthy soils) 10

$\begin{array}{ll}1.1 .3 \text { Beleidsmodellen } & 11\end{array}$

1.1.4 Operationele modellen $\quad 11$

1.2 Geschiedenis en toekomst van bodemhydrofysische gegevens 12

$\begin{array}{ll}1.2 .1 & \text { Staringreeks }\end{array}$

1.2.2 Priapus 13

1.2.3 Vooronderzoek bodemhydrofysische gegevens voor BIS-Nederland 14

1.2.4 BIS - Bodem Informatie Systeem (2014) 14

1.2.5 DINO - Data en Informatie van de Nederlandse Ondergrond $\quad 15$

1.2.6 BRO - Basis Registratie Ondergrond $\quad 15$

1.2.7 INSPIRE - Infrastructure for Spatial Information in the European Community 16

1.3 Impact van het project 16

1.3.1 Bijdrage aan de BRO-doelstellingen $\quad 16$

1.3.2 Bijdrage aan 'Key Recommendations' van het UN Data Revolution rapport 17

1.3.3 Bijdrage aan Sustainable Development Goals 17

$\begin{array}{lll}1.4 & \text { Aanleiding en probleemstelling } & 18\end{array}$

1.5 Projectdoelstelling $\quad 19$

$\begin{array}{llr}1.6 & \text { Leeswijzer } & 19\end{array}$

2.1 Gegevenskeuze, kwaliteit en presentatie 20

2.1.1 Welke bodemhydrofysische gegevens in BIS 20

$\begin{array}{ll}2.1 .2 \text { Kwaliteitscriteria } & 20\end{array}$

2.2 Selectiewijze monsterlocaties $\quad 21$

2.2.1 Latin Hypercube Sampling $\quad 22$

2.2.2 Selectiewijze bemonsteringslocaties $\quad 22$

$\begin{array}{lll}2.3 & \text { Bemonsteringswijze } & 23\end{array}$

2.4 Analysemethoden $\quad 24$

2.4.1 Textuur $\quad 24$

2.4.2 Gloeiverlies $\quad 25$

2.4.3 Retentie- en onverzadigde waterdoorlatendheidskarakteristiek 25

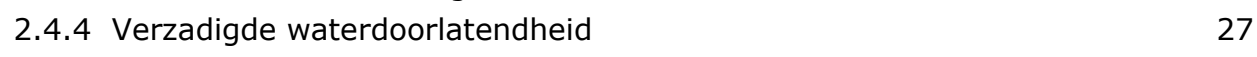

2.4.5 Karakteristiek-parametrisering met Mualem-Van Genuchten 28

$\begin{array}{lll}3.1 & \text { Veldgegevens } & 32\end{array}$

$\begin{array}{lll}3.2 & \text { Textuur } & 35\end{array}$

3.3 Dichtheid en gloeiverlies 38

3.4 Mualem-Van Genuchten-parameters van de prefit $\quad 41$

3.5 Mualem-Van Genuchten-parameters van de eindfit $\quad 41$

3.6 Koppeling extra monsters Priapus met metadata $\quad 44$ 
4.1 Rapport en database $\quad 46$

4.2 Gebruiksadvies $\quad 46$

4.2.1 Aandachtspunten 46

4.2.2 Fuzzy-classificatie $\quad 47$

$\begin{array}{lll}4.3 & \text { Raadplegen bodemfysische data in BIS } & 47\end{array}$

$\begin{array}{llr}5 & \text { Conclusies } & 48\end{array}$

$\begin{array}{ll}\text { Literatuur } & \mathbf{5 0}\end{array}$

$\begin{array}{lll}\text { Bijlage } 1 & \text { Excelfilter en fit-programma } & 54\end{array}$

Bijlage 2 Grafieken van de meetgegevens (2012-2016) 60

$\begin{array}{lll}\text { Bijlage } 3 & \text { Geocodes } & 75\end{array}$ 


\section{Woord vooraf}

Dit onderzoek voor de verzameling van bodemhydrofysische gegevens voor het Bodem Informatie Systeem en de Bodem Registratie Ondergrond is onderdeel van het programma Bodem Informatie Systeem (BO-11, Natuur en Regio, thema 017). Het onderzoek is gefinancierd door het ministerie van Economische zaken. Wij zijn Frans Lips van dit ministerie erkentelijk voor zijn nuttige inbreng.

Wageningen, december 2016 


\section{Samenvatting}

Bodemfysische gegevens of, specifieker, bodemhydrofysische (BhF) gegevens, zoals de waterretentiekarakteristiek en doorlatendheidskarakteristiek, organische stofgehalte, textuurgegevens, profielbeschrijving en andere metagegevens zijn belangrijke basisgegevens bij het modelleren van transport van water en opgeloste stoffen in de onverzadigde zone, maar worden ook gebruikt voor tal van andere toepassingen. Omdat er grote behoefte is aan actuele BhF-gegevens van hoge kwaliteit en omdat de huidige databases onvoldoende opschalingsmogelijkheden bieden, zijn in dit project BhF-gegevens van 118 nieuwe monsters bepaald. De BhF-gegevens en de bijbehorende beschrijvende gegevens zijn ondergebracht in BIS (Bodem Informatie Systeem).

Daarnaast zijn oudere Priapus-gegevens in BIS ondergebracht, onder te verdelen in drie categorieën:

1. Van 44 bestaande hoogwaardige monstergegevens in Priapus zijn de daarvan beschikbare gegevens ondergebracht in BIS en zijn deze fysiek gekoppeld aan bestaande profielbeschrijvingen in BIS. Het betreft hier ten minste de afgeleide doorlatendheid-drukhoogte-vochtgehalte-relaties, maar meestal ook textuur en organische stofgegevens. Van deze Priapus-monsters zijn de ruwe meetgegevens niet altijd aanwezig.

2. In Priapus zijn vraagtekens gezet bij afgeleide gegevens van een groot aantal andere monsters. Nieuwe inzichten hebben in dit project geleid tot verbeterde software (2014), waarmee afgeleide gegevens betrouwbaarder dan voorheen bepaald kunnen worden. In 2016 is dit getest op meetgegevens van 10 Priapus-monsters, waarvan de afgeleide gegevens oorspronkelijk als onvoldoende waren gekwalificeerd. De afgeleide gegevens van de opnieuw doorgerekende monsters voldoen alsnog aan de gestelde criteria en zijn samen met eventueel overige beschikbare meetgegevens en profielbeschrijvingen in BIS opgenomen.

3. Tot slot is er van 53 oude Priapus-monsters met hoge kwaliteit een koppeling op papier gelegd met beschrijvende gegevens in de literatuur

Resumerend zijn in totaal 172 monsters fysiek in BIS ondergebracht en in potentie nog eens 53 (de koppeling van de 53 oudere gegevens maakt het eenvoudiger om in een vervolgtraject de gegevens te digitaliseren en passend te maken voor het BIS en BRO-format).

Zoals beoogd, zijn alle opschalingseenheden nu gevuld met gegevens van minimaal twee locaties per opschalingseenheid, met uitzondering van de eolische afzetting met zeer fijn zand in de ondergrond, waarvan één monster aanwezig is. Vanwege de nauwkeurig uitgevoerde selectie voorafgaand aan de bemonsteringen zijn vrijwel alle gewenste opschalingseenheden aangetroffen en bemonsterd. Er is geen volledige garantie te geven dat de op de bodemkaart aangegeven bodemprofielen ook daadwerkelijk in het veld worden aangetroffen. Bovendien kunnen veldschattingen afwijken van de achteraf in het laboratorium bepaalde textuurverdeling.

In het lab wordt met zeer korte tijdsintervallen gemeten. Dit resulteert in grote databestanden. Het is daarom wenselijk het aantal datapunten te reduceren voorafgaand aan verdere verwerking. In dit project is daarom een filter ontwikkeld waarmee een kleinere set met essentiële ongewijzigde data overblijft. Kleine schommelingen in de data (ruis) zorgen normaliter voor grote afwijkingen in de afgeleide data van met name de onverzadigde waterdoorlatendheid in het natte traject. Het filter zorgt er tevens voor dat minder last wordt ondervonden van deze variaties. In het filter worden geen data aangepast, alleen selectief volgens een vast protocol weggelaten. In dit project is daarnaast een Excelrekensheet ontwikkeld dat op een veel kleiner detailniveau de tussen- en eindresultaten van de fitprocedure kan analyseren dan tot op heden gebeurde. Hierdoor kunnen oorzaken van eventuele onvolkomenheden eerder in het proces worden getraceerd. Invoergegevens voor dit programma zijn de drukhoogten, vochtgehalten en tijd van de verschillende meetmethoden en de verzadigde waterdoorlatendheden. Uitvoergegevens zijn de afgeleide BhF-eigenschappen en de Mualem-Van Genuchten (MVG-)parameters. Het filter en het rekensheet zorgen samen voor betrouwbaardere afgeleide gegevens. 


\section{$1 \quad$ Inleiding}

De fysische conditie van de bodem (bodemvocht, bodemlucht, bodemtemperatuur en bodemstructuur) bepaalt in grote mate de wisselwerking tussen biochemische kringlopen, nutriëntenkringlopen, biodegradatie van organische toxische stoffen en de emissie of absorptie van broeikasgassen uit of in de grond. De bodem bepaalt daarom in grote mate de functie en de inrichting van onze leefomgeving. Door intensivering van het grondgebruik is een goed fundamenteel begrip van de bodem en van de relaties ervan met de omgeving nodig om gezonde voeding en een veilige en prettige leefomgeving te kunnen waarborgen.

Het verzamelen en interpreteren van fundamentele gegevens over de bodem die een directe relatie hebben met de stroming en retentie van water en stoffen, de luchthuishouding en de beschikbaarheid van organische stof, is het domein van de bodemfysica of, specifieker, bodemhydrofysica (BhF) en vormt de basis voor een groot aantal onderzoeksdisciplines.

Omdat er door het brede toepassingsgebied grote behoefte is aan actuele BhF-gegevens van hoge kwaliteit en omdat de huidige databases onvoldoende opschalingsmogelijkheden bieden, zijn in dit project BhF-gegevens van goede kwaliteit van 118 nieuwe monsters bepaald. De BhF-gegevens en de bijbehorende beschrijvende gegevens zijn ondergebracht in BIS (Bodem Informatie Systeem). Daarbij zijn bemonsteringslocaties gericht geselecteerd, zodat later via Latin Hypercube Sampling zo veel mogelijk opschalingsmogelijkheden ontstaan.

Daarnaast zijn bestaande (oudere) Priapus-gegevens in BIS ondergebracht, onder te verdelen in drie categorieën:

1. Van 44 bestaande hoogwaardige monstergegevens in Priapus zijn de daarvan beschikbare gegevens ondergebracht in BIS en zijn deze fysiek gekoppeld aan bestaande profielbeschrijvingen in BIS. Het betreft hier ten minste de afgeleide doorlatendheid-drukhoogte-vochtgehalte-relaties, maar meestal ook textuur en organische stofgegevens. Van deze Priapus-monsters zijn de ruwe meetgegevens niet altijd aanwezig.

2. In Priapus zijn vraagtekens gezet bij afgeleide gegevens van een groot aantal andere monsters. Nieuwe inzichten hebben in dit project geleid tot verbeterde software (2014), waarmee afgeleide gegevens betrouwbaarder dan voorheen bepaald kunnen worden. In 2016 is dit getest op meetgegevens van 10 Priapus-monsters, waarvan de afgeleide gegevens oorspronkelijk als onvoldoende waren gekwalificeerd. De afgeleide gegevens van de opnieuw doorgerekende monsters voldoen daarmee alsnog aan de gestelde criteria en zijn tezamen met eventueel overig beschikbare meetgegevens en bestaande profielbeschrijvingen in BIS opgenomen.

3. Tot slot is er van 53 oude Priapus-monsters met hoge kwaliteit een koppeling op papier gelegd met beschrijvende gegevens in de literatuur

Resumerend zijn in totaal 172 monsters fysiek in BIS ondergebracht en in potentie nog eens 53 (de koppeling van de 53 oudere gegevens maakt het eenvoudiger om in een vervolgtraject de gegevens te digitaliseren en passend te maken voor het BIS- en BRO-format). Met de resulterende datareeks wordt een belangrijke basis gelegd voor het faciliteren van landsdekkende, omgevingsgerichte onderzoeken.

\subsection{Nut en noodzaak van bodemhydrofysische gegevens}

\subsubsection{Bodemhydrofysische gegevens als basis}

Overheden en diverse nationale en internationale organisaties maken zich steeds meer zorgen over bodemdegradatie en klimaatverandering als gevolg van de intensivering en veranderingen van landgebruik. De voedselvoorziening, biodiversiteit en natuurlijke ecosystemen worden beïnvloed en 
samenlevingen worden bedreigd. Het gevolg daarvan is dat er toenemende behoefte is aan inzichten, methoden en technieken om te komen tot 'duurzaam en gezond bodemgebruik'. De BhF-wetenschap speelt een grote rol bij maatschappelijke onderwerpen die te maken hebben met oogstopbrengsten, effecten van de bodemeigenschappen op klimaatverandering door broeikasgasemissies, uitspoeling en retentie van nutriënten en contaminanten, natuurwaarden, bodemverdichting, erosie, efficiëntie van watergebruik en de invloed van de bodem op de veiligheid van dijken. Voor het faciliteren van gedegen onderzoeken zijn landsdekkende gegevens nodig van goede kwaliteit.

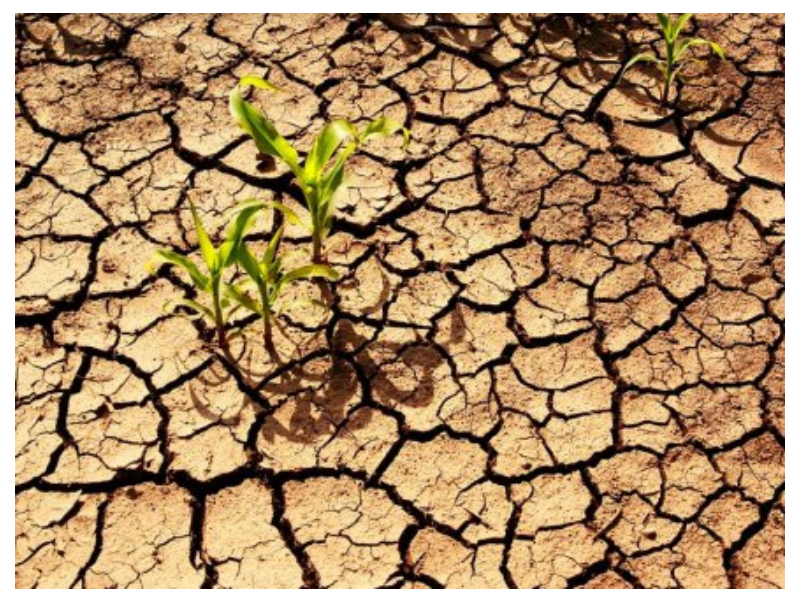

Figuur 1.1 Scheuren in een kleigrond door krimp beïnvloeden de fysische eigenschappen.

Voorbeelden van belangrijke BhF-gegevens zijn het organische stofgehalte van de bodem, textuur, structuur, dichtheid, krimp- en zweleigenschappen van klei- en veengronden, waterafstotende eigenschappen in bijvoorbeeld dijken of na bosbranden, maar vooral ook de waterretentie- en doorlatendheidskarakteristieken, die direct gebruikt kunnen worden voor het modelleren van transport van water en opgeloste stoffen in de onverzadigde zone.

De bodem kent verschillende gebruiksvormen of gebruiksfuncties. Vaak zijn deze bodemfuncties bewust aan een bepaalde locatie gekoppeld, omdat de bodemeigenschappen daar geschikt zijn voor de functie. De dynamiek in het bodemvocht speelt daarin een cruciale rol. De bodem is een belangrijke parameter in de waterkringloop tussen atmosfeer, grondwater en rivieren. Grondwater, bodem en waterdamp zijn media die zich gedragen als paden waarlangs stoffen worden getransporteerd. De systemen zijn sterk gekoppeld met de uitwisseling van energie en warmte tussen het aardoppervlak en atmosfeer en zijn daarom belangrijk in weersvoorspellingen en voorspellingen van klimaatverandering op regionale en wereldschaal. De wisselwerking tussen fysische en biochemische processen, nutriënten, organische en toxische stoffen, (de)nitrificatie of de emissie of absorptie van broeikasgassen uit of in de grond komt ook tot uitdrukking in de in Nederland nog vrij onbekende term 'bodemgezondheid'. De term is echter sterk in opkomst en past in deze tijd van integrale benaderingen.

\subsubsection{Gezonde bodems (Eng: healthy soils)}

Bodemgezondheid wordt vaak geassocieerd met schone grond, ofwel met grond die geen verontreinigingen bevat, en aan de directe relatie met gezondheid van mens en dier. De term 'gezonde bodem' poogt echter vooral aan te duiden dat de bodem zelf gezond, ofwel van goede kwaliteit is. Een gezonde bodem is in staat om duurzaam goed te functioneren, uiteindelijk resulterend in een gezonde leefomgeving voor mens en dier. Hoewel een dergelijke omschrijving van een gezonde bodem in Nederland nog weinig gebruikt wordt, is hij elders in de wereld al veel toegepast. De driehoek Fysisch-Chemisch-Biologisch omspant de eigenschappen van de bodem die bepalend zijn voor de bodemgezondheid. De term is in het leven geroepen omdat de bodem nu te vaak vanuit eenzijdig perspectief wordt bezien. De bodem is echter een complex systeem dat een integrale benadering vraagt. Alleen met een integrale benadering kunnen grote vraagstukken die betrekking 
hebben op bijvoorbeeld voedselzekerheid en het verminderen van effecten van een veranderend klimaat, op een duurzame wijze worden opgelost. De bodemgezondheid wordt momenteel bedreigd door klimaatverandering, resulterend in bijvoorbeeld intensere regens en overvloedige erosie of, door verkeerd landgebruik, het uitmijnen van organische stof en essentiële nutriënten. Hierdoor staan ook de kwantiteit en de kwaliteit van de gewassen die verbouwd worden onder druk.

\subsubsection{Beleidsmodellen}

Beleidseffecten worden meestal gekwantificeerd met behulp van rekenmodellen. De BhF-gegevens, die als basisinvoer voor deze modellen nodig zijn, hebben grote invloed op de uitkomsten van de modellen. Het belang van een goede BhF-dataset wordt daarmee onderstreept. Enkele belangrijke beleidsmodellen die in Nederland bij omgevingsgericht onderzoek gebruikt worden, zijn:

- SWAP: Soil-Water-AtmosPhere model - Eendimensionale simulatie van waterstroming en plantengroei in het systeem van bodem, water en atmosfeer (Van Dam et al. 2008).

- LGM: Landelijk Grondwater Model - Het model beschrijft de stroming van het diepere, verzadigde grondwater in een meerlagensysteem, waarbij goed doorlatende watervoerende pakketten zijn gescheiden door slecht doorlatende scheidingslagen (Pastoors, 1992).

- PEARL: Pesticide Emission At Regional and Local scales - Dit model berekent de uit- en afspoeling van gewasbeschermingsmiddelen (ook wel bestrijdingsmiddelen genoemd) naar het grond- en oppervlaktewater (Tiktak et al. 2000, 2003, 2004).

- STONE: Samen Te Ontwikkelen Nutriënten Emissie model - Dit beleidsevaluatiemodel is in samenwerking met het RIVM en RIZA ontwikkeld voor nationale beleidsevaluaties, maar kan voor verschillende schaalniveaus worden gebruikt. Het model kwantificeert de effecten van het landbouwen milieubeleid op de uitspoeling van $\mathrm{N}$ en $\mathrm{P}$ naar het grondwater en de afspoeling naar het oppervlaktewater. Het accent ligt daarbij op landbouwkundige bronnen, zoals dierlijke mest en kunstmest (Wolf et al. 2003).

- WATERNOOD en HELP-tabellen: Waternood is een methode die als leidraad wordt gebruikt voor het ontwerp en beheer van waterhuishoudkundige infrastructuur in het regionale waterbeheer. De STOWA ondersteunt deze methode via het Waternood-instrumentarium. De recentste HELP-tabellen zijn opgenomen in het instrumentarium (Van Bakel et al. 2005).

- NHI: Nationaal Hydrologisch Instrumentarium - Een geïntegreerd landsdekkend grond- en oppervlaktewatermodel van Nederland. De resultaten van het hydrologisch model worden ingezet voor landelijke beleid (Delta-beslissingen, Kader Richtlijn Water, Nitraatrichtlijn etc.) en voor operationele ondersteuning voor de waterverdeling tijdens droogte. Het is opgebouwd uit diverse gekoppelde concepten: Verzadigde zone (grondwater) - MODFLOW, Onverzadigde zone MetaSWAP, Regionaal oppervlaktewater - MOZART, Landelijk oppervlaktewater - DM (SOBEK) (Hoogewoud et al. 2013).

- SIMGRO: gedateerd acroniem voor SIMulatie van GROndwater - SIMGRO 6 combineert diverse deelprocesmodellen tot één generiek model: MetaSWAP voor de eendimensionale onverzadigde stroming, MODFLOW voor de regionale grondwaterstroming en SWQN voor het oppervlaktewater (Van Walsum et al. 2010).

\subsubsection{Operationele modellen}

Buiten de beleidsmodellen worden diverse (experimentele) modellen gebruikt op projectbasis. Ook deze modellen zijn afhankelijk van de BhF-basisgegevens:

- MODFLOW - MODulair driedimensionaal grondwater FLOW model - Dit eindige differentiegrondwaterstromingsmodel, dat oorspronkelijk door de US Geological Survey is gemaakt, is modulair opgebouwd (Prince et al. 1988; Berlitz et al. 1993).

- HYDRUS-1D - Een 'public domain' model voor de eendimensionale analyse van water-, stoffen- en warmtetransport in variabele poreuze media. Vanwege het public domain-karakter wordt het wereldwijd op grote schaal toegepast (HYDRUS 2D/3D: Vogel et al. 1996).

- HYDRUS-2D/3D - De twee-/driedimensionale variant van Hydrus-1D (Simunek et al. 1999).

- MicroFEM - Een eindig elementen-grondwatermodel voor meerdere watervoerende lagen, geschikt voor zowel stationaire als dynamische grondwaterstroming (Hemker et al. 1997).

- FUSSIM2 - Twee-/driedimensionaal simulatiemodel voor de beschrijving van water- en zouttransport in poreuze media, de opname van water en nutriënten in de wortel, reductie van 
evaporatie van water aan het bodemoppervlak, oppervlakkige afstroming, (de)nitrificatie en bodemtemperatuur. Het model is verder gekoppeld met het organische stofmodel MOTOR (Heinen et al. 1998).

- EmMan3G - Afgeleid en versimpeld FUSSIM2-model dat bedoeld is om continue metingen van nutriënten in de bodem en de uitspoeling ervan naar het grondwater - evenals de meting van bodemvochtgehalten en drainage sturende bodemparameters in vollegronds kasteelten gedeeltelijk te vervangen.

- ZEUS - Berekent op basis van bodemhydrofysische kenmerken en profielgegevens afgeleide functionele kenmerken, zoals kritieke z-waarden, beschikbare hoeveelheden vocht in de wortelzone en ondergrond, C- en kD-waarden en berging (Wesseling et al. 2013).
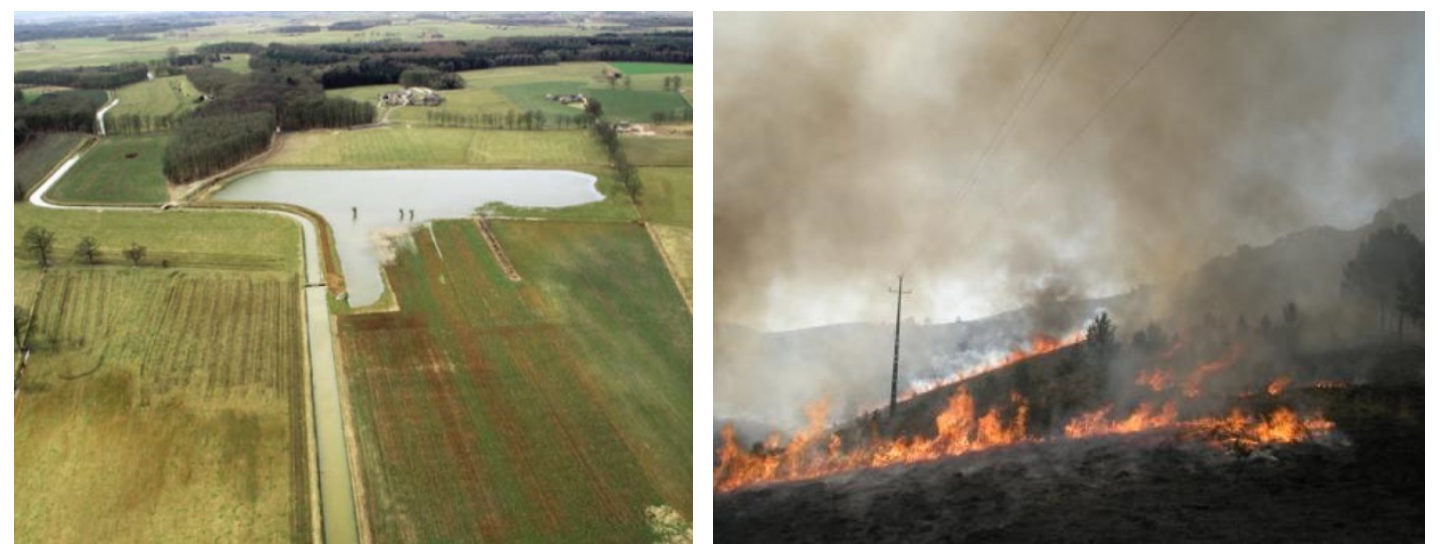

Figuur 1.2 Foto links: Proeflocatie in Salland - onderzoek naar de invloed van kortstondige inundatie van grasland op draagkracht, af- en uitspoeling van nutriënten en grasopbrengst.

Foto rechts: Proeflocatie in Portugal - onderzoek naar de invloed van bosbranden op de relatie tussen BhF-eigenschappen en erosie.

\subsection{Geschiedenis en toekomst van bodemhydrofysische gegevens}

Al sinds het ontstaan van de bodemfysische wetenschap kort na WOII is men bezig om BhF-gegevens systematisch te rangschikken en is men op zoek naar mogelijke generalisaties. In Nederland heeft deze systematiek voor het eerst vorm gekregen in de Staringreeks (Wösten et al. 1987). In de loop der tijd zijn regelmatig aanvullingen uitgevoerd en updates uitgebracht:

- Staringreeks 1987

- Staringreeks 1994

- Staringreeks 2001

- Priapus 2010

- Bodemfysische gegevens in BIS 2014

- Bodemhydrofysische gegevens in BIS - Update 2016

Hieronder wordt een beknopte geschiedenis van de BhF-reeksen gegeven en de logische opvolgingen die vervolgens plaatsvonden. De laatste jaren wordt hard gewerkt om niet alleen BhF-gegevens, maar ook veel andere gegevens over de bodem dusdanig te standaardiseren en te verzamelen dat zij onder te brengen zijn in BIS, maar ook in landelijke en vervolgens Europese databanken, zoals de Nederlandse BRO en het Europese INSPIRE. 


\subsubsection{Staringreeks}

In 1987 is de Staringreeks voor het eerst uitgebracht aan de hand van 273 grondmonsters (Wösten et al. 1987). In 1994 en in 2001 heeft er een uitbreiding plaatsgevonden tot respectievelijk 620 en 832 monsters die ondergebracht zijn in 18 boven- en 18 ondergronden (Wösten et al. 1994, 2001).

Uitgangspunt bij de opzet van de Staringreeks was de Bodemkaart van Nederland (1: 50 000). De textuurklassen van de daarop aangegeven bodemhorizonten zijn op diverse plekken in Nederland bemonsterd in zowel de boven- als ondergrond (wortelzone en daaronder). Vervolgens is van elke onderscheiden boven- en ondergrond een gemiddelde waterretentie- en waterdoorlatendheidskarakteristiek bepaald. De Staringreeks bevat geen gegevens van afzonderlijke monsters, maar geeft gemiddelden van de karakteristieken. Om het gebruik in simulatiemodellen te vereenvoudigen, zijn de karakteristieken behalve in tabelvorm ook beschreven met 'klasse-vertaalfuncties'. Dit zijn analytische vergelijkingen die beschreven worden met de Mualem-Van Genuchten parameters (Mualem, 1976; Van Genuchten, 1980). Aanvullend zijn nog 'continue vertaalfuncties' (Eng.: pedotransfer functions) gegeven die de klasse-vertaalfuncties kunnen genereren op basis van lutumgehalte, leem- en organische stofgehalte, M50, dichtheid en een boven- of ondergrondaanduiding.

\section{Voor- en nadelen Staringreeks}

Het grote voordeel van de Staringreeks is het overzichtelijke en snel toepasbare karakter. Dit heeft ervoor gezorgd dat het veel gebruikt wordt in modelstudies. Nadeel is echter dat de ruwe data en beschrijvende gegevens van de monsters onbekend zijn. Gebruikers van de Staringreeks hebben behoefte aan meer differentiatie van de BhF-gegevens en aan een hogere betrouwbaarheid van de gemiddelde karakteristieken per bouwsteen. Dit inzicht is van belang om de betrouwbaarheid van uitkomsten van modellen te kunnen kwantificeren. De indeling van de Staringreeks is gemaakt op basis van textuur, aard van het moedermateriaal (grove indeling) en het organische stofgehalte (grove indeling). Er wordt niet of nauwelijks onderscheid gemaakt in dichtheid, bodemtype en afzettingsmilieu. De pakking, sortering en het organische stofgehalte van oude dekzanden zijn bijvoorbeeld beduidend anders dan bij de stuifzandgronden. Als gevolg hiervan verwacht men ook dat de BhF-karakteristieken verschillen. Hiermee is echter in de huidige Staringreeks geen rekening gehouden. De BhF-karakteristieken zijn gemiddelden binnen dezelfde bouwsteen, waardoor het hydraulische gedrag van alle bodemhorizonten binnen een bouwsteen hetzelfde is.

\subsubsection{Priapus}

In opdracht van het Project Kwaliteitsslag Databestanden \& Modellen van het WOT-MNP en de Helpdesk Vitaal Landelijk Gebied heeft er, als gevolg van de veranderde gebruikerswensen, een kwaliteitsverbetering plaatsgevonden. Tussen 2006 en 2008 zijn afgeleide gegevens en beschrijvende gegevens van grondmonsters, waarop onder meer de Staringreeks is gebaseerd, opgezocht in de archieven van Stiboka, ICW, Staring Centrum en Alterra. De afgeleide BhF-data zijn opgenomen in het gegevensbestand Priapus (Verzandvoort et al. 2012), terwijl van de beschrijvende (veld)gegevens een referentie is gegeven in het rapport. De gegevens zijn getoetst aan strenge kwaliteitseisen. De database is niet ontworpen ter vervanging van de Staringreeks, maar als een uitbreiding daarvan.

Voor de certificering tot Kwaliteitsstatus A in 2008 werd een groot deel van de monstergegevens vervolgens afgeschermd voor gebruik, omdat op grond van de gehanteerde criteria afgeleide gegevens of soms ook metingen onvoldoende volledig of betrouwbaar werden geacht, of omdat onvoldoende beschrijvende (veld)informatie van de grondmonsters aanwezig was. Mede omdat de bodem continu aan verandering onderhevig is en een groot deel van de monsters in Priapus (en Staringreeks) ouder is dan 30 jaar, zijn op dit moment onvoldoende recente en gecertificeerde gegevens van BhF-karakteristieken beschikbaar om nieuwe bodemschematisaties zoals PAWN (Wösten et al. 1988) of BOFEK2012 (Wösten et al. 2013) af te kunnen afleiden of om landsdekkende of regionale studies uit te kunnen voeren met bijvoorbeeld STONE.

Voor- en nadelen Priapus

De afgeleide analysereeksen zijn nu per monster in Priapus opgenomen en uitgebreid getest op kwaliteitskenmerken. Door het ontsluiten van kwalitatief hoogwaardige afgeleide data, gecombineerd 
met de mogelijkheid om deze BhF-data te koppelen aan meta-informatie per monsterpunt, wordt tegemoetgekomen aan de gebruikerswensen ten aanzien van het kunnen kwantificeren van de betrouwbaarheid van uitkomsten van hydrologische modellen en de variatie tussen de karakteristieken van monsters met verwante eigenschappen. De Priapus-opzet maakt een bredere toepassing van de data mogelijk dan de Staringreeks, omdat op een veel kleiner detailniveau eigenschappen zijn te vergelijken. Bovendien kan de gebruiker zelf voortschrijdende inzichten gebruiken om bijvoorbeeld klasse-vertaalfuncties te genereren die betrekking hebben op het afzettingsmilieu. Afgeleide datasets hebben in Priapus alleen het kwaliteitskenmerk 'goed' als zij een voldoende bereik hebben en als de data consistent is met de overig verkregen informatie op het meetpunt. Daarom zijn er veel minder hoogwaardige datasets (91 stuks) beschikbaar dan in de Staringreeks, die de afgeleide gegevens gebaseerd heeft op 832 monsters. Hierdoor zijn geen landsdekkende onderzoeken met Priapus mogelijk. Een ander belangrijk nadeel is dat vaak alleen de afgeleide gegevens in Priapus zijn opgenomen en niet de meetreeksen zelf, waardoor voortschrijdende inzichten niet toe te passen zijn op de oorspronkelijke ruwe meetdata. Bovendien ontbreken vaak aanvullende meetgegevens, zoals de verzadigde waterdoorlatendheid en het organische stofgehalte.

\subsubsection{Vooronderzoek bodemhydrofysische gegevens voor BIS-Nederland}

Vanwege het ontbreken van voldoende gecertificeerde BhF-gegevens in Priapus is in de aanloop naar de update voor BIS onderzocht welke aanvulling minimaal nodig is (Knotters et al. 2011).

Verzandvoort et al. (2011) stellen een nieuwe indeling in BhF-eenheden voor. Die indeling moet voldoen aan onder meer de eis dat BhF-karakteristieken op meerdere niveaus, zowel bodemkundig als geologisch, kunnen worden ingedeeld en geselecteerd. De criteria op basis waarvan opschaling dan kan plaatsvinden, zijn:

- afzettingsmilieu (6 hoofdklassen);

- textuur (6 leemklassen, 5 mediaanklassen, 10 lutumklassen);

- boven- en ondergrond (2 klassen);

- gehalte aan organische stof ( 6 klassen voor minerale gronden en 3 klassen voor moerige gronden).

Het theoretisch aantal ruimtelijke opschalingseenheden is volgens Knotters et al. (2011) dan gelijk aan 2364. Dit aantal is te groot om uit elke eenheid een monster te nemen. Daarom wordt monstername volgens een Latin Hypercube-steekproef aanbevolen. In dat geval moet ervoor gezorgd worden dat in ieder geval alle bovengenoemde klassen in Priapus zijn vertegenwoordigd met ten minste twee monsters per klasse. Meerdere monsters per klasse zijn nodig om de nauwkeurigheid van geschatte gemiddelden te kunnen kwantificeren. Rekening houdend met de al aanwezige monsters in Priapus, concludeerden Knotters et al. (2011) dat er nog ten minste 50 horizonten bemonsterd zouden moeten worden, resulterend in een minimale steekproefomvang van 100. Aanbevolen wordt de monsterlocaties gericht te selecteren met als doel de hiaten in Priapus op te vullen. De Latin-Hypercube werkwijze heeft het voordeel dat het de gebruiker in staat stelt zelf de grootte van de ruimtelijke opschaling te kiezen. Het nadeel van de werkwijze is dat opschalings- of aggregatiemethoden voor kleine gebieden of voor 'empty domains' niet eenvoudig zijn. Het gebruik van modellen is hierbij onvermijdelijk.

De nieuwe ruimtelijke indeling sluit nauw aan op de geologische indeling die Deltares gebruikt. Dit is gunstig voor de voorziene samenvoeging van het Dinoloket en het BIS in de Basis Registratie Ondergrond.

\subsubsection{BIS - Bodem Informatie Systeem (2014)}

Bodemgegevens staan in de top 5 van meest door de overheid gebruikte gegevens. Het betreft dan veelal bodemgegevens uit het Bodemkundig Informatie Systeem (BIS) dat in beheer is bij Alterra. BIS-Nederland bevat, behalve BhF-meetdata én afgeleide BhF-gegevens, enorm veel informatie over de Nederlandse bodem die vanaf de jaren zestig tot op heden op systematische wijze is verzameld en bewerkt. BIS-Nederland bestaat uit de volgende onderdelen:

- Lokale bodemgegevens over de bodemkwaliteit, bodemopbouw en hydrofysische en chemische eigenschappen per laag; 
- Landsdekkende bodem- en grondwatertrappenkaart schaal 1 : 50 000;

- Landsdekkende bodemkaart schaal 1 : 250 000;

- Bodem- en grondwatertrappenkaarten op schalen 1 : 25000 en 1 : 10 000;

- Kaarten en bestanden met gedetailleerde beschrijving van de grondwaterdynamiek;

- DeltaBIS: mogelijkheid tot vervaardiging van kaarten 'op recept' door de gebruiker zelf.

\subsubsection{DINO - Data en Informatie van de Nederlandse Ondergrond}

DINO staat voor Data en Informatie van de Nederlandse Ondergrond. Daar waar BIS zich richt op de Nederlandse bovengrond tot circa 1,2 m-mv, richt TNO zich met DINO op de bodem daaronder. DINO is de centrale opslagplaats voor geowetenschappelijke gegevens over de diepe en ondiepe ondergrond van Nederland (voor diverse gebruiksdoeleinden), die te maken hebben met grondwater, delfstoffen en bodemchemie. Vanaf 2006 zijn voor DINO ongeveer 200 boringen tot 30 à 40 meter diepte uitgevoerd met zeer zware apparatuur en zijn er circa 6000 analyses verricht (mondelinge informatie TNO, 2014). Het betreft steekboringen, waarin sonderingen en meestal een boorgatmeting zijn uitgevoerd. De zware apparatuur is ongeschikt voor het nemen van monsters ten behoeve van BIS vanwege de gevoeligheid van hydraulische kenmerken voor mechanische verstoringen. DINO en BIS bestrijken elk een eigen toepassingsgebied en zijn complementair.

\subsubsection{BRO - Basis Registratie Ondergrond}

BRO staat voor Basis Registratie Ondergrond. Binnen BRO wordt de ondergrond gedefinieerd als de ruimte tussen het maaiveld en de aardkern (Hooghart, 2011). BRO is een van de Geo-basisregistraties van het ministerie van Infrastructuur en Milieu. Het besluit tot invoering van BRO is in nauwe samenwerking met de overige bestuursorganen tot stand gekomen en zal ook gezamenlijk verder worden uitgewerkt tot een eenduidig, landelijk systeem.

In BRO wordt zowel BIS als DINO opgenomen, omdat beide afzonderlijke informatiesystemen onvoldoende met elkaar zijn verbonden en de gegevens vaak andere doelen dienen. Het gebruik van geologische en bodemkundige gegevens vindt veelal plaats in de vorm van kaarten en profielen die gebaseerd zijn op geologische en bodemkundige modellen. In BRO worden verder de diepe mijnbouwwet-gerelateerde gegevens opgenomen. Die worden momenteel verstrekt via NLOG (NL Olie-en Gasportaal).

BRO maakt onderdeel uit van het Stelsel van Basisregistraties. Met dit stelsel verbetert de overheid haar dienstverlening door belangrijke gegevens over onder andere personen, bedrijven, gebouwen en de ondergrond binnen de overheid te delen via de zogeheten 'webdiensten'. Dankzij goed gestructureerde formulieren en protocollen kunnen gebruikers gegevens opvragen of een berekening laten uitvoeren. Op dezelfde manier kunnen gebruikers binnenkort grondwaterstanden opvragen of een dwarsdoorsnede maken van een driedimensionaal ondergrondmodel. Ook kunnen bronhouders en adviesbureaus rechtstreeks een vraag stellen aan het loket. Al deze gegevens zijn kosteloos beschikbaar en toegankelijk voor overheden, bedrijven en burgers.

Beleidsmakers beschikken met BRO over meer en betere gegevens, waardoor ze sneller en beter gefundeerde beslissingen kunnen nemen ten aanzien van een breed spectrum aan beleidsvragen. Zij krijgen met BRO direct toegang tot de gegevens die voor hen van belang zijn. Het belang van adequate informatie over de bodem en ondergrond neemt in de toekomst verder toe, ook in het kader van Europese regelgeving. De exacte inhoud (registratieobjecten) van BRO wordt in samenwerking met belanghebbenden vastgelegd in de Catalogus BRO. Daartoe moet op grond van het wetsvoorstel voor de start van de BRO in ieder geval één $A M v B$ en één ministeriële regeling worden vastgesteld (planning 2017). In de AMvB worden de brondocumenten van registratieobjecten aangewezen die in BRO worden opgenomen. BhF-gegevens zijn momenteel nog geen officieel onderdeel van BRO. Vanwege het belang van BhF-gegevens bij het beantwoorden van vele maatschappelijke vragen, wordt ernaar gestreefd deze gegevens in 2017 als officiële registratieobjecten in BRO op te nemen.

BRO geeft tevens invulling aan (een deel van) verplichtingen die voortvloeien uit de Europese richtlijn INSPIRE (zie hieronder). Deze richtlijn verplicht lidstaten onder meer gegevens over de ondergrond 
via internet ter beschikking te stellen. Dit betekent dat er een wettelijke verplichting voor alle bestuursorganen komt om gegevens, die in de catalogus BRO genoemd worden, aan te leveren.

De minister van Infrastructuur en Milieu wordt bronhouder van de gegevens die op het moment van de inwerkingtreding van de wet op de BRO in BIS en DINO staan. Eventuele terugmeldingen op deze gegevens zijn daarmee een verantwoordelijkheid van de minister, ook in het geval deze gegevens in het verleden door een ander bestuursorgaan zijn aangeleverd. Conform de andere basisregistraties is het uitgangspunt dat BRO de best mogelijke gegevens bevat, maar geen $100 \%$ garantie geeft op de juistheid. Bestuursorganen kunnen dus worden aangesproken op hun zorgplicht. Indien bij de totstandkoming van de brondocumenten zorgvuldigheid is betracht, heeft het bestuursorgaan aan zijn verplichtingen voldaan en geldt er geen verdere aansprakelijkheid.

\subsubsection{INSPIRE - Infrastructure for Spatial Information in the European Community}

BRO is opgezet met als doel de informatiehuishouding ten aanzien van de Nederlandse ondergrond te verbeteren. Met BRO geeft Nederland ook invulling aan de Europese INSPIRE-eisen voor de thema's uit de Annex II Geology en de Annex III: Soil, Environmental monitoring facilities. De INSPIRE-richtlijn verplicht de Europese lidstaten geo-informatie over 34 thema's te voorzien van metadata, deze te harmoniseren en beschikbaar te stellen via het INSPIRE-portaal volgens leveringsvoorwaarden die het gebruik niet onnodig belemmeren. INSPIRE zorgt er zo voor dat geo-informatie van goede kwaliteit beschikbaar, vindbaar en bruikbaar is en dat de inhoud ervan, ook over de landsgrenzen heen, op elkaar is afgestemd. Hiervoor richten de lidstaten een netwerk in dat bestaat uit één Europees en meerdere nationale internetportalen en netwerkdiensten. Via dit INSPIRE-netwerk krijgen zowel overheden als burgers en bedrijven toegang tot de geo-informatie. INSPIRE is gestart in 2007 en zal naar verwachting in 2019 volledig operationeel zijn. Een Europees Ruimtelijke Data Infrastructuur helpt beleidsmakers bij het beantwoorden van grensoverschrijdende vraagstukken.

\subsection{Impact van het project}

\subsubsection{Bijdrage aan de BRO-doelstellingen}

Het lopende project BodemhydroFysische (BhF) gegevens - Update 2016 is nog niet officieel gekoppeld aan een of meerdere registratieobjecten van BRO. Omdat binnen dit BhF-deelonderzoek tevens boorprofielen worden gemaakt, is het wel gerelateerd aan het registratieobject boormonsterprofielen (in 2016 zijn in zware zwavelgronden 9 boorprofielen aan het bestand toegevoegd). Echter, in 2016 zijn voornamelijk van 27 monsters uitgebreide BhF-gegevens bepaald, die in de nabije toekomst in BRO opgenomen kunnen gaan worden en vereiste basisgegevens vormen voor modellen die gebruikt worden bij het beantwoorden van belangrijke maatschappelijke vragen. Tezamen met de al bestaande dataset, die in de periode 2012-2015 is bepaald, is er voor BRO een dataset beschikbaar van 172 uitgebreide BhF-gegevens. Of de werkelijk aan BRO toe te voegen aantallen groter of kleiner zijn, is afhankelijk van de datasoorten die als registratieobject zullen worden aangemerkt. In 2017 wordt verdergegaan met het verzamelen van BhF-gegevens, zodat het aantal dat hiervoor is aangegeven groter zal zijn. Het zwaartepunt in het BhF-deelonderzoek ligt uiteraard op het bepalen van de BhF-basisgegevens van de diverse horizonten, waarmee hydrologische modellen worden gevoed. Tezamen met de andere data in BIS/BRO ontstaat een zeer waardevolle relatie tussen enerzijds de hydrofysische basisgegevens en anderzijds profielbeschrijvingen, grondwatergegevens, chemische samenstelling van de bodem, geomorfologische gegevens en datamodellen. 


\subsubsection{Bijdrage aan 'Key Recommendations' van het UN Data Revolution rapport}

Data en modellen zijn van levensbelang voor besluitvorming en leveren het ruwe materiaal voor af te leggen verantwoording. Zonder de juiste informatie is het ontwerpen, monitoren en evalueren van beleid een bijna onmogelijke opgave.

Zo begint het rapport 'A world that counts' van de UN Expert Advisory Group on a Data Revolution for Sustainable Development (Gonzalez-Morales et al. 2014). De adviesgroep doet een aantal aanbevelingen (key recommendations) die ervoor moeten zorgen dat het verzamelen, opslaan en verstrekken van data beter wordt afgestemd op de informatie die we nodig hebben om de vorderingen op weg naar de Sustainable Development Goals (SDG's) te monitoren.

De doelstellingen van BRO komen in grote lijnen overeen met de doelstellingen van de UN Expert Advisory Group (Tabel 1). Wel moet worden opgemerkt dat wat betreft de realisatie van de Landelijke Voorziening van BRO er nog onvoldoende wordt gekeken naar de aansluiting bij de internationale bodemwereld. De relatie met SDG's is geen ontwerpcriterium.

Tabel 1 Enkele 'Key Recommendations' vanuit Gonzalez-Morales et al. 2014 en de bijdrage daaraan vanuit het gehele project BIS/BRO.

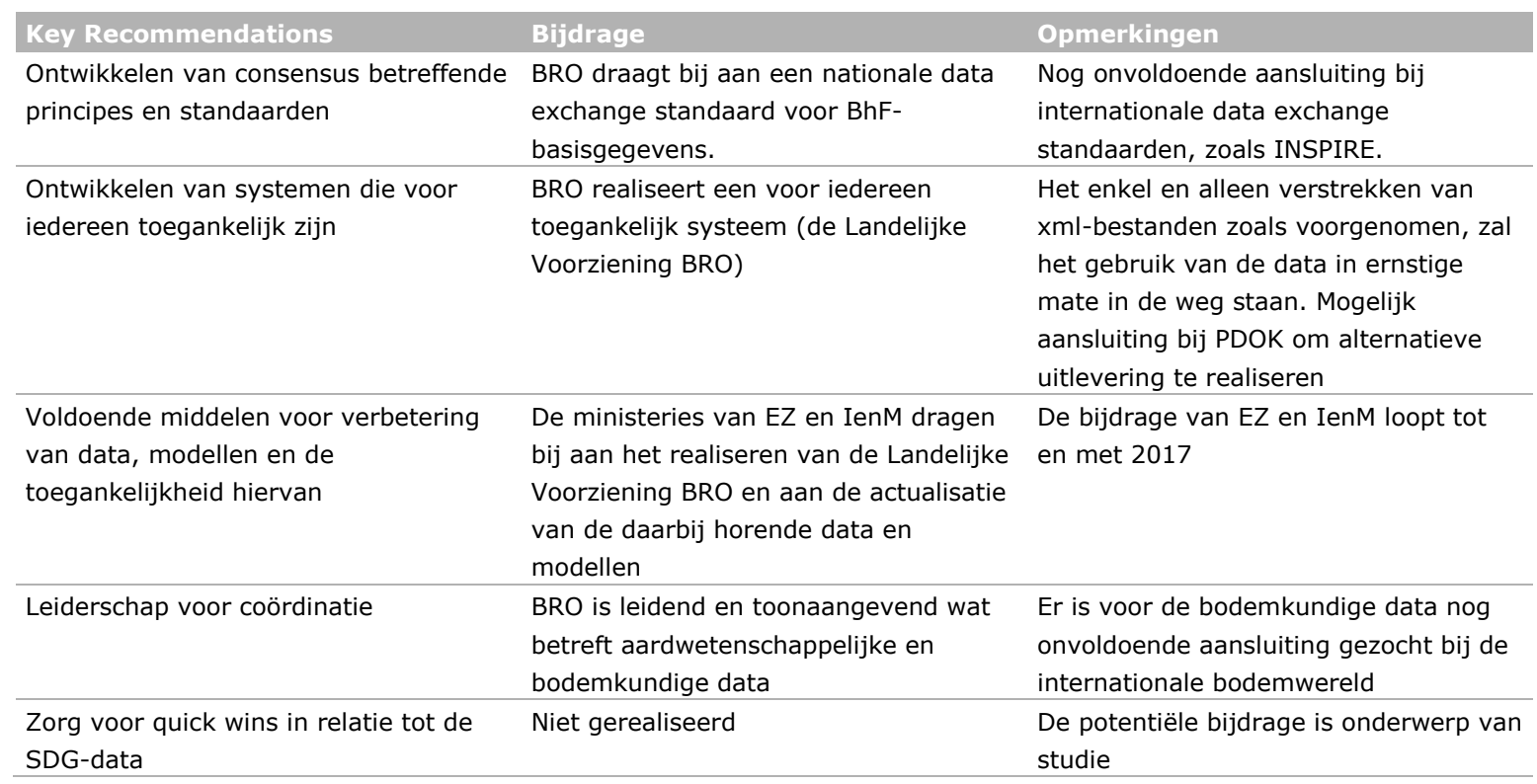

\subsubsection{Bijdrage aan Sustainable Development Goals}

Nederland heeft de ambitie en streeft ernaar om alle door de regeringsleiders van de lidstaten van de Verenigde Naties vastgestelde Duurzame Ontwikkelingsdoelen (SDG's) in 2030 te behalen (Ploumen, 2016). BhF-gegevens zijn gerelateerd aan een aantal van deze SDG's. Elke SDG kent een aantal indicatoren (E/CN, 2016). De via dit project in BIS/BRO opgeslagen gegevens en modellen hebben in een aantal gevallen een relatie met die indicatoren. Voor de BhF-gegevens zijn deze in Tabel 2 weergegeven. 
Tabel 2 Enkele SDG's en indicatoren (E/CN, 2016), en de bijdrage die BhF-gegevens daaraan leveren.

\begin{tabular}{|c|c|c|c|}
\hline SDG & Indicator & Bijdrage & Opmerking \\
\hline $\begin{array}{l}2 . \\
\text { Geen honger, bereik } \\
\text { voedselzekerheid en } \\
\text { duurzame landbouw }\end{array}$ & $\begin{array}{l}2.4 .1 \text {. } \\
\text { Percentage duurzame } \\
\text { landbouw (landbouw gericht } \\
\text { op het behoud van } \\
\text { ecosystemen, op } \\
\text { klimaatbestendigheid en op } \\
\text { een voortdurende } \\
\text { verbetering van land- en } \\
\text { bodemkwaliteit }\end{array}$ & $\begin{array}{l}\text { BhF-gegevens dragen } \\
\text { fundamenteel bij aan het } \\
\text { begrip en het in kaart } \\
\text { brengen van de bodem ten } \\
\text { behoeve van optimalisatie en } \\
\text { verduurzaming van onder } \\
\text { andere de agrarische sector }\end{array}$ & \\
\hline $\begin{array}{l}6 . \\
\text { Schoon water en sanitair }\end{array}$ & $\begin{array}{l}6.1 .1 \\
\text { Percentage onbedreigde } \\
\text { watervoorraad } \\
6.4 \\
\text { Watergebruik efficiëntie } \\
6.6 \\
\text { Bescherming water- } \\
\text { gerelateerde ecosystemen }\end{array}$ & $\begin{array}{l}\text { BhF-gegevens worden } \\
\text { gebruikt bij het doorrekenen } \\
\text { van uitspoeling van } \\
\text { nutriënten en } \\
\text { verontreinigingen naar het } \\
\text { grond- en oppervlaktewater, } \\
\text { voor het optimaliseren van } \\
\text { irrigatiegiften en sturing op } \\
\text { ecosysteembehoud }\end{array}$ & \\
\hline $\begin{array}{l}13 . \\
\text { Klimaatactie }\end{array}$ & $\begin{array}{l}13.2 .1 \\
\text { Integreer mitigerend beleid } \\
\text { in politieke besluitvorming }\end{array}$ & $\begin{array}{l}\text { BhF-gegevens dragen bij aan } \\
\text { het voorspellen van de } \\
\text { vochttoestand van de bodem } \\
\text { onder veranderend klimaat. } \\
\text { De vochttoestand heeft een } \\
\text { bewezen forse relatie met de } \\
\text { mate van emissie van } \\
\text { broeikasgassen }\end{array}$ & $\begin{array}{l}\text { De combinatie van } \\
\text { vochttoestand, mestsoorten } \\
\text { en bodemgegevens zijn } \\
\text { cruciaal bij emissiereductie. } \\
\text { Dergelijk onderzoek wordt } \\
\text { meegenomen in } \\
\text { beleidsvorming }\end{array}$ \\
\hline $\begin{array}{l}17 . \\
\text { Partnerschap om } \\
\text { doelstellingen te bereiken }\end{array}$ & $\begin{array}{l}\text { Aantal samenwerkings- } \\
\text { overeenkomsten en } \\
\text {-programma's inzake SDG } \\
\text { gerelateerde } \\
\text { gegevensverwerking }\end{array}$ & $\begin{array}{l}\text { - Samenwerking met TNO } \\
\text { inzake BRO } \\
\text { - Lid van het European Soil } \\
\text { Bureau Network } \\
\text { - Samenwerking met ISRIC } \\
\text { - World Data Center for } \\
\text { Soils }\end{array}$ & \\
\hline
\end{tabular}

\section{$1.4 \quad$ Aanleiding en probleemstelling}

Het totaal aantal betrouwbare bodemhydrofysische gegevens voor een bodemkundig informatiesysteem is niet toereikend om landsdekkende dan wel regionale studies uit te kunnen voeren. De Staringreeks (Wösten et al. 1987, 1994, 2001) geeft weliswaar gemiddelden van de hydraulische karakteristieken, maar bevat geen gegevens van afzonderlijke monsters. Het bevat ook geen beschrijvende gegevens, omdat de gegevens van verschillende monsterplekken zijn geclusterd tot gemiddelde bouwstenen. Bovendien zijn de gegevens voor een groot deel gebaseerd op data van meer dan 30 jaar geleden.

Gebruikers van bodemhydrofysische gegevens hebben behoefte aan meer differentiatie, recentere gegevens, een hogere betrouwbaarheid van de gemiddelde karakteristieken per bouwsteen en aan de beschrijvende gegevens per monsterlocatie. Met de Priapus-database is daartoe een eerste aanzet gedaan: het maakt een bredere toepassing van de data mogelijk dan de Staringreeks, omdat op 
monsterniveau eigenschappen zijn te vergelijken. Bovendien hebben de afgeleide data, die uit verschillende bronnen zijn verzameld, een strenge kwaliteitsslag ondergaan. Er is echter behoefte aan veel meer kwalitatief hoogwaardige en recente bodemhydrofysische data, die tevens geschikt zijn voor opschaling op basis van meerdere criteria, zoals boven- en ondergrond, gehalte aan organische stof, textuur en afzettingsmilieu. Behalve aan de afgeleide gegevens is er ook behoefte aan de meetdata die aan de afgeleide data ten grondslag liggen, zodat nieuwe wetenschappelijke inzichten optimaal gebruikt kunnen worden, resulterend in verbeterde afgeleide datasets. De meetdata zijn niet aanwezig in de Staringreeks en Priapus.

\subsection{Projectdoelstelling}

Het hoofddoel van dit project is het aanvullen van de Priapus-gegevens met nieuwe, kwalitatief hoogwaardige bodemhydrofysische data die voldoen aan de eisen zoals hierboven zijn omschreven. De nieuw verkregen afgeleide data alsook de meetdata worden in dit project ondergebracht in BIS en kunnen daardoor op eenvoudige en eenduidige wijze gebruikt worden, ook in combinatie met andere in BIS opgeslagen bodemkundige gegevens. Er wordt verder een koppeling gelegd tussen bestaande bodemhydrofysische data in Priapus en bestaande profielbeschrijvingen in BIS en/of de literatuur. Bodemhydrofysische data waarvan momenteel alleen in de literatuur metadata bekend zijn, kunnen daarmee in de toekomst eenvoudiger in BIS worden ondergebracht. Door eenduidige ontsluiting in BIS kan het vervolgens relatief eenvoudig ondergebracht worden in het Nederlandse BRO en het Europese INSPIRE, uiteindelijk resulterend in een systeem dat beleidsmakers en andere gebruikers helpt bij het beantwoorden van lokale, nationale en grensoverschrijdende vraagstukken.

\subsection{Leeswijzer}

In hoofdstuk 1 is voornamelijk aandacht besteed aan het belang van bodemhydrofysische gegevens voor onderzoek en aan de geschiedenis en toekomst van bodemhydrofysische data. Hoofdstuk 2 geeft een overzicht van de gebruikte veld- en laboratoriummethoden. Hoofdstuk 3 is een vrij uitgebreide presentatie van de belangrijkste componenten van de veld-, laboratorium- en deskgegevens in tabelvorm. Voor verdere details wordt verwezen naar de databases zelf: BIS en/of Priapus.

Hoofdstuk 4 geeft een korte terugblik op de resultaten, het gebruik van de resultaten en een doorkijk naar de toekomst. In de bijlagen is het voor dit onderzoek ontwikkelde analyseprogramma voor hydraulische eigenschappen toegelicht en zijn de bodemhydraulische eigenschappen van de nieuwe monsters grafisch weergegeven. 


\section{$2 \quad$ Materialen en methoden}

Dit hoofdstuk geeft een toelichting op de keuze van de te verzamelen gegevens en op de veld- en laboratoriummethoden die gebruikt zijn om deze gegevens te verzamelen en te interpreteren.

\subsection{Gegevenskeuze, kwaliteit en presentatie}

\subsubsection{Welke bodemhydrofysische gegevens in BIS}

Het is binnen de huidige omstandigheden niet mogelijk om alle bodemhydrofysische gegevens te bepalen en op te nemen in BIS. Daarom wordt een selectie van de meest gebruikte parameters toegepast. De parameters zijn in overeenstemming met de kwaliteitscriteria zoals die in de volgende paragraaf worden besproken:

- Textuur

- Droge bulkdichtheid

- Gloeiverlies (organische stofgehalte)

- Verzadigde waterdoorlatendheid

- Waterretentiekarakteristiek

- Waterdoorlatendheidskarakteristiek

- Beschrijving van de retentie- en doorlatendheidskarakteristiek met de Mualem-Van Genuchtenvergelijkingen

- Profielbeschrijving

- Landgebruik huidig en vorig jaar

- Coördinaten

Voor de bullets 5 tot en met 7 geldt dat de hydraulische karakteristieken (retentiekarakteristiek en waterdoorlatendheidskarakteristiek) met verschillende analytische vergelijkingen beschreven kunnen worden. Omdat geen enkel model in staat is om de metingen volledig correct te beschrijven en omdat er nog steeds nieuwe modellen worden ontwikkeld, is ervoor gekozen om van deze items in ieder geval alle betrouwbaar geachte ruwe meetgegevens op te nemen in BIS. De ruwe meetgegevens bestaan uit een tijdreeks met monstergewichten, drukhoogtewaarden op meerdere diepten en gemiddelde vochtgehalten per tijdstap. Uit deze ruwe basisreeks is in beginsel met elk gewenst model de puntenwolk af te leiden die de waterdoorlatendheid als functie van de drukhoogte of het vochtgehalte beschrijft. Met de ruwe gegevens is de gebruiker dus altijd in staat om met eigen voorkeursmodellen een complete set hydraulische parameters af te leiden, de zogenaamde afgeleide gegevens. Dit maakt de reeks ook voor toekomstig gebruik geschikt. Omdat de Mualem-Van Genuchten-vergelijkingen momenteel wereldwijd erg veel gebruikt worden, zijn deze modelparameters, bij wijze van voorbeeld, eveneens in BIS opgenomen. Ook de doorlatendheidspuntenwolk is met een 1-modale (of meer) Van Genuchten-vergelijking afgeleid en opgenomen in BIS. Om de datareeks in BIS te vergroten, worden kwalitatief hoogwaardige afgeleide data uit de bestaande Priapus-database ook in BIS opgenomen. Van deze gegevens zijn de meetgegevens helaas niet altijd meer te achterhalen. In die gevallen kan niet aan de bovengenoemde compleetheidseisen worden voldaan, maar worden de gegevens toch opgenomen.

\subsubsection{Kwaliteitscriteria}

De kwaliteitscriteria voor de bodemhydrofysische data die zijn ondergebracht in Priapus, staan vermeld in Stolte et al. (2007) en in Verzandvoort et al. (2012). Deze kwaliteitscriteria worden ook voor de nieuwe bodemhydrofysische afgeleide data van BIS nagestreefd en uitgebreid met meetdata. De kwaliteitseisen zijn enerzijds gebaseerd op de volledigheid van de metagegevens, parametersoorten en meetbereik en anderzijds op de kwaliteit van de gegevens zelf, zoals die van de afgeleide waterdoorlatendheidsdata en de Mualem-Van Genuchten-krommen. In Tabel 3 zijn - in het 
kader van het nastreven van de minimaal benodigde informatie - de hoofdgroepen gegeven die opgenomen worden in BIS. Oude gegevens uit Priapus die opgenomen worden in BIS voldoen eveneens aan de kwaliteitscriteria, maar niet in alle gevallen aan de volledigheidseisen.

Tabel 3 Hoofdgroepgegevens (minimale variant) van de bodemhydrofysische data in BIS.

\begin{tabular}{|c|c|}
\hline Hoofdgroepnaam & Omschrijving \\
\hline Beschrijving & Hoofdkenmerken van grondmonsters \\
\hline Landen & Namen van landen \\
\hline Waterschappen & Namen van waterschappen \\
\hline Coördinatenstelsels & Beschrijving van coördinatenstelsels \\
\hline Bodemgebruik & Beschrijving van bodemgebruik \\
\hline Grondwatertrappen & Definities van grondwatertrappen \\
\hline Geologie & Beschrijving van geologische ondergrond \\
\hline GrondsoortLegenda & Beschrijving van grondsoorten \\
\hline Grondsoort & Grondsoorten waarop indeling Staringreeks is gebaseerd \\
\hline Staringreeks & De bouwstenen van de Staringreeks \\
\hline Eigenschappen & De bodemhydrofysische eigenschappen van de grondmonsters \\
\hline Textuur & Gemeten textuurgegevens van bodemmonsters \\
\hline TextuurClassificatieSystemen & Beschrijvingen van classificatiesystemen voor textuur \\
\hline TextuurClassificatieGrenzen & Definities van textuurklassen \\
\hline Metingen & Gegevens over de metingen \\
\hline Meetmethoden & De gebruikte meetmethoden \\
\hline Laboratoria & De laboratoria \\
\hline Meetresultaten & De gemeten vochtgehalten, drukhoogten en doorlatendheden \\
\hline Fitten & Gegevens over de fits \\
\hline Fitmethodes & Methoden om te fitten \\
\hline
\end{tabular}

De afgeleide gegevens, zoals de puntenwolk van de drukhoogte en de onverzadigde waterdoorlatendheid - die wordt verkregen door modellering van de meetgegevens van de verdampingsmethode - zijn alle gecontroleerd op consistentie en fysische verklaarbaarheid. De afgeleide gegevens kunnen soms afwijkend gedrag vertonen. Dit kan optreden door meetfouten, maar ook door ruis, temperatuurinvloeden of als het gebruikte model onvoldoende in staat is om de metingen te fitten. In de eerste drie gevallen, waarin de afgeleide gegevens leidden tot twijfel over een of meerdere gemeten datapunten of zelfs over een hele tensiometerreeks, zijn deze datapunten niet gepresenteerd in dit rapport en niet opgenomen in de BIS-database. Indien daarentegen de afgeleide gegevens onvoldoende nauwkeurig door het model kunnen worden beschreven terwijl de meetgegevens zelf betrouwbaar worden geacht, zijn de daaraan ten grondslag liggende metingen wel in BIS opgenomen.

\subsection{Selectiewijze monsterlocaties}

De indelingscriteria voor bemonstering, zoals voorgesteld door Verzandvoort et al. (2012), zijn boven- of ondergrond, afzettingsmilieu ( 6 hoofdklassen), textuur ( 6 leemklassen, 5 klassen op basis van mediaan zandfractie en 10 lutumklassen) en organische stofgehalte ( 6 klassen bij minerale gronden, 3 klassen bij moerige gronden). Het aantal mogelijke opschalingseenheden wordt daarmee maximaal 2364. Als in elke eenheid ten minste 2 monsterlocaties moeten liggen, betekent dit een steekproefomvang die op dit moment niet haalbaar is. Omdat niet alle 2364 combinaties kunnen worden bemonsterd, is door Knotters et al. (2011) een methode voorgesteld om op slimme wijze met een beperkt aantal monsters zo veel mogelijk bodemhydrofysische informatie toe te voegen aan de BIS- en BRO-database. 


\subsubsection{Latin Hypercube Sampling}

Bij de opzet van de aanvullende steekproef en bij de ruimtelijke opschaling kan wel rekening worden gehouden met het feit dat niet alle opschalingseenheden steekproefpunten bevatten (empty domains). Belangrijk is dat in alle klassen waarop de indeling in opschalingseenheden is gebaseerd, monsters liggen. Indien dit wordt voorgesteld als een tabel met rijen en kolommen, betekent dit dat niet alle vakjes zijn gevuld, maar dat wel alle rijen en kolommen informatie bevatten. Dit kan worden bewerkstelligd door Latin Hypercube Sampling. Bij de bemonstering is de aanbeveling gevolgd dat zo veel mogelijk klassen naar boven- en ondergrond, afzettingsmilieu, textuur en gehalte aan organische stof uiteindelijk in BIS en BRO worden opgenomen met ten minste twee monsters per klasse. Meerdere monsters per klasse zijn nodig om de nauwkeurigheid van geschatte gemiddelden te kunnen kwantificeren of om benaderingen, waarbij wordt geloot uit bodemfysische karakteristieken, voor individuele locaties mogelijk te maken (bootstrapping).

Knotters et al. (2011) bevelen aan om de monsterlocaties gericht te selecteren, met als doel de hiaten in Priapus op te vullen. Geconcludeerd werd dat er minimaal 50 aanvullende horizonten bemonsterd moeten worden voor een goede dekking van de ruimtelijke hoofdaggregatie-eenheden. Bij uitvoering in duplo betekent dit dat er minimaal 100 monsters per bepalingsmethode genomen en doorgemeten moeten worden. Bij de bemonstering en analyse is een prioriteitsvolgorde aangehouden: de grootste oppervlakten per opschalingseenheid zijn daarbij het eerst gemonsterd.

In Tabel 4 is een overzicht gegeven van de nog ontbrekende opschalingseenheden in Priapus. Dit overzicht is het uitgangspunt geweest voor de te selecteren bemonsteringslocaties.

\subsubsection{Selectiewijze bemonsteringslocaties}

In BIS zijn op dit moment al duizenden profielbeschrijvingen beschikbaar van locaties verspreid over Nederland. Bij het zoeken naar geschikte bemonsteringslocaties is daarvan gebruikgemaakt. Bij het selecteren van de locaties is een aantal criteria gehanteerd:

- De gewenste textuurklasse van Tabel 4 moet aanwezig zijn over een dikte van ten minste $20 \mathrm{~cm}$, zodat de kans op voorkomen wordt vergroot en er een voldoende diep profiel voor bemonstering aanwezig is.

- De gewenste textuurklasse moet aanwezig zijn in de boven- of ondergrond, overeenstemmend met Tabel 4.

- De locatie heeft de geologische ontstaanswijze zoals aangegeven in Tabel 4.

Vanuit de verkregen selectie is een overzicht met locatie- en contactgegevens gegenereerd. De potentiële bemonsteringslocaties zijn daarna verder handmatig geselecteerd op basis van de volgende eigenschappen:

- De bemonsteringslocaties moeten voldoende verspreid over Nederland liggen. Er is bijvoorbeeld rekening gehouden met bemonstering van locaties van mariene afkomst uit zowel het zuidwesten als het noorden.

- Om de kans op aantreffen van de betreffende textuur in het veld te vergroten, zijn locaties aan de randen van een kaartvlak van de Bodemkaart van Nederland (schaal 1: 50 000) vermeden, omdat daar de variatie in textuur groter is. In het algemeen geldt dat naarmate de profielbeschrijvingen ouder zijn, de locaties minder nauwkeurig zijn vastgelegd.

- In een aantal gevallen was het praktisch om op dezelfde locatie zowel een boven- als ondergrond te bemonsteren.

Van de locaties die aan alle criteria voldeden, zijn de eigenaren benaderd om toestemming voor bemonstering te vragen. 
Tabel 4 Oppervlakten van klassen waarin nul of één Priapus-monster ligt. De monsternamedatum geeft de prioriteitsvolgorde voor verzameling van aanvullende gegevens.

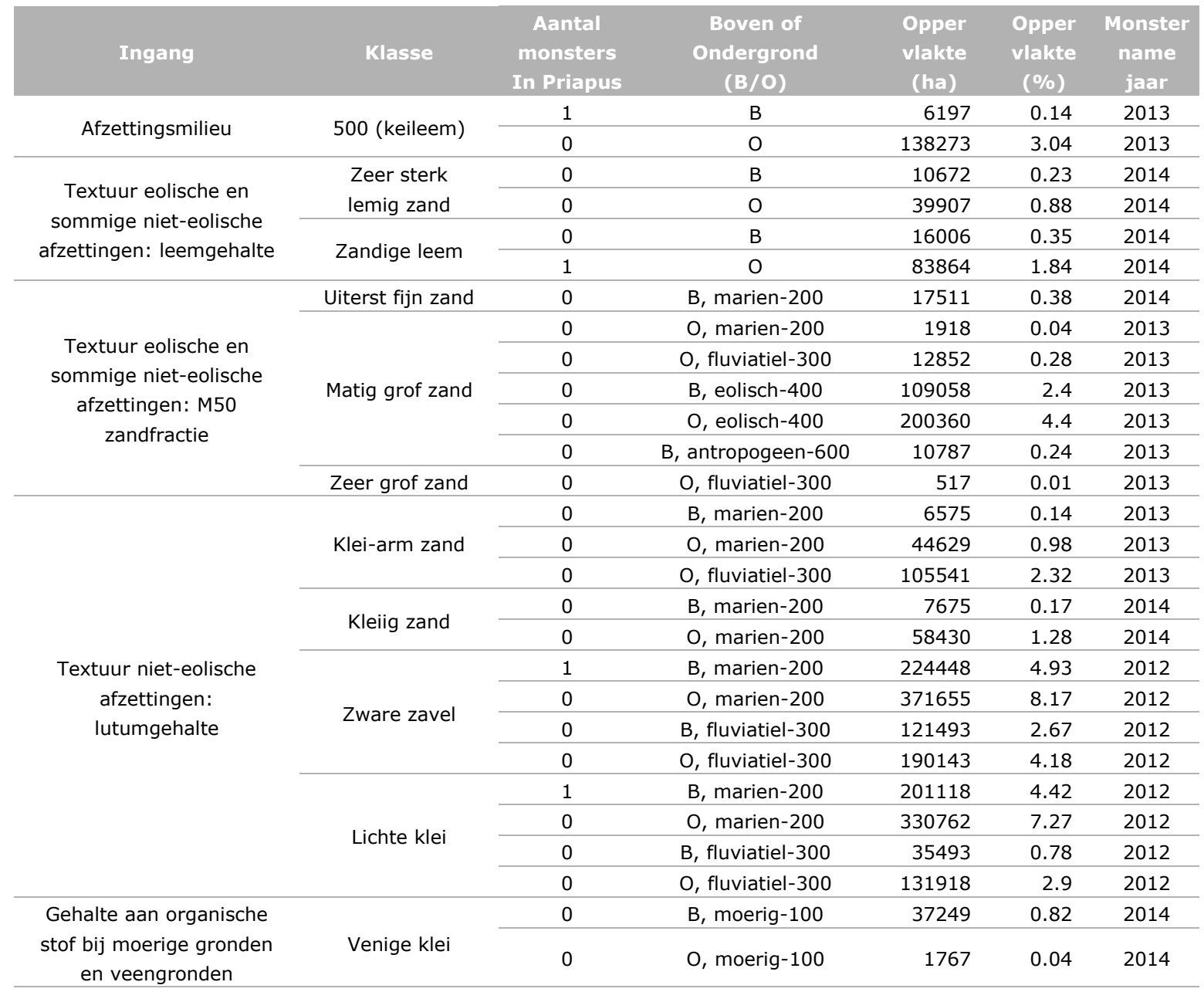

\subsection{Bemonsteringswijze}

Op de geselecteerde locaties zijn de volgende monsters in duplo genomen in het midden van de betreffende horizont:

- Roestvrijstalen monsterringen (hoogte $\mathrm{h}=5 \mathrm{~cm}$, diameter $\mathrm{D} \approx 5 \mathrm{~cm}$ ) voor onverstoorde monsters ten behoeve van de bepaling van de retentiecurve op de zandbak voor het traject $h=0$ tot $-100 \mathrm{~cm}$ $(\mathrm{pF}=2)$.

- PVC-monsterringen $(\mathrm{h}=8 \mathrm{~cm}, \mathrm{D} \approx 10 \mathrm{~cm}$ ) voor onverstoorde monsters ten behoeve van de bepaling van de retentiecurve en curve van de onverzadigde waterdoorlatendheid op de verdampingsopstelling voor het traject $h=-10$ tot $-700 \mathrm{~cm}(\mathrm{pF}=1$ tot $\mathrm{pF}=2.8)$.

- PVC-monsterringen $(\mathrm{h}=10 \mathrm{~cm}, \mathrm{D} \approx 20 \mathrm{~cm}$ ) voor onverstoorde monsters ten behoeve van de bepaling van de verzadigde waterdoorlatendheid $(h=0)$.

- Verstoorde grondmonsters in zakken ter bepaling van de textuur en organische stof.

De ringen voor de onverstoorde monsters zijn dusdanig voorzichtig met de hand in de grond gebracht dat de structuur van de grond behouden is gebleven. Daarna zijn de monsterringen rondom uitgegraven en handstrak met folie omwikkeld zodat er geen grond uit de ringen kon vallen. In het lab zijn de monsters verder geprepareerd. De $100 \mathrm{~cm}^{3}$ ringen zijn in het veld al voorgeprepareerd met een vlakke boven- en onderzijde. Vervolgens zijn de monsters dezelfde dag nog bij 4 graden Celsius opgeborgen voor verdere analyse in het lab. Bij de bemonstering van de ondergronden is de bovengrond eerst voorzichtig afgegraven tot de bovenzijde van het benodigde profiel, waarbij de bovenzijde netjes vlak is afgewerkt. Het eigenlijke profiel is daarbij onverstoord gebleven, hetgeen betekent dat er niet overheen is gelopen en niet verticaal met de schop in is gestoken. 
Tijdens monstername is tevens een profielbeschrijving gemaakt en zijn onder andere de volgende gegevens genoteerd op de veldcomputer:

- Monstercode

- Locatie

- $\mathrm{XY}$ coördinaten

- Horizont

- Diepte boven- en onderkant monster

- Monsterdatum

- Monsternemer

- Bodemgebruik

- Grondwatertrappen (GtCode, GLG, GHG)

- Geologische ondergrond

- Grondsoort

\subsection{Analysemethoden}

\subsubsection{Textuur}

Voor bodemkartering worden van oudsher de textuurklassen van de Stiboka (Stichting voor Bodemkartering) gebruikt. Voor kleigronden werden andere fractieverdelingen gehanteerd dan voor zandgronden. De Nederlandse norm NEN 5753/C1 (2006, 2009) en de gelijksoortige internationale norm ISO 11277 (2009) schrijven geen specifieke fracties voor, maar geven wel een overzicht van de meest gebruikte fracties. De Rijks Geologische Dienst (RGD) gebruikt enigszins afwijkende fractieverdelingen in het bereik 50 tot $150 \mu \mathrm{m}$. Voor de nieuw te analyseren monsters voor BIS wordt een combinatie van beide systemen aangehouden, zodat ze geldig zijn ongeacht de gehanteerde indeling. Voor een uniforme verdeling worden voor alle grondsoorten dezelfde verdelingen aangehouden.

In Tabel 5 zijn de gehanteerde textuurklassen weergegeven en de laboratoriummethode die voor de fractiebepaling is gebruikt. De gebruikte laboratoriummethoden zijn beschreven in de ISO 11277 (2009). Uitgegaan wordt van de fracties ten opzichte van de minerale delen, waarvan de hoofdonderdelen als volgt worden benoemd:

- Lutum: $0-2 \mu \mathrm{m}$

- Silt: 2 - $50 \mu \mathrm{m}$

- Leem: 0 - $50 \mu \mathrm{m}$

- Zand: $50-2000 \mu \mathrm{m}$

De fractie $<63 \mu \mathrm{m}$ wordt in het Chemisch Biologisch Laboratorium Bodem (CBLB) geanalyseerd volgens de pipet- en natte-zeefmethode. De fractie 63 - $2000 \mu \mathrm{m}$ wordt daarna in het Bodemfysisch Laboratorium verder geanalyseerd door middel van droogzeven.

In het laboratorium wordt de op $<2000 \mu \mathrm{m}$ voorgezeefde grond met waterstofperoxide voorbehandeld om aanwezige organische stof te oxideren. Daarna volgt een behandeling met zoutzuur om aanwezige carbonaten in oplossing te brengen. Voor ijzerrijke grond kan het gewenst zijn de korrelgrootteverdeling van de minerale delen zonder ijzeroxide te bepalen. Hierbij wordt het aanwezige ijzeroxide in oplossing gebracht. Na verwijdering van de opgeloste zouten wordt het monster door zeven in twee fracties verdeeld. De hoofdfractie met grovere deeltjes wordt gedroogd en gewogen en via zeven met verschillende maaswijdte onderverdeeld in subfracties en vervolgens nogmaals gewogen. De hoofdfractie met de kleinere deeltjes wordt onderverdeeld in subfracties op basis van verschil in bezinkingssnelheid. Hierbij wordt van een suspensie van het monster in een maatcilinder, na toevoeging van een peptisatiemiddel op verschillende tijdstippen en diepten, in de cilinder een monster gepipetteerd. Tijdstippen en diepten voor het pipetteren van bepaalde fracties worden met de wet van Stokes berekend. De gepipetteerde suspensie wordt ingedampt en gedroogd en door weging wordt het massapercentage van de gepipetteerde fractie bepaald. 
Tabel 5 Gehanteerde fracties voor BIS en de gebruikte labmethode.

$\begin{array}{ll}\text { Textuurklasse }(\mathrm{\mu m}) & \text { Gebruikte methode } \\ <2 & \text { Pipetmethode } \\ 2-16 & \text { Pipetmethode } \\ 16-50 & \text { Pipetmethode } \\ 50-63 & \text { Natte-zeefmethode } \\ 63-105 & \text { Droge-zeefmethode } \\ 105-150 & \text { Droge-zeefmethode } \\ 150-210 & \text { Droge-zeefmethode } \\ 210-420 & \text { Droge-zeefmethode } \\ 420-2000 & \text { Droge-zeefmethode }\end{array}$

\subsubsection{Gloeiverlies}

Het gloeiverlies is een maat voor het organisch stofgehalte van een grondmonster. Hoe groter het aandeel organisch materiaal, hoe groter het gloeiverlies zal zijn. In het laboratorium wordt het in het veld genomen verstoorde grondmonster gezeefd over een zeef met $2 \mathrm{~mm}$ maaswijdte. De fractie kleiner dan $2 \mathrm{~mm}$ wordt gedroogd bij $105^{\circ} \mathrm{C}$, gewogen en vervolgens gegloeid bij $550{ }^{\circ} \mathrm{C}$. Het gloeiverlies $w_{g v}$ wordt vervolgend berekend uit

$w_{g v}=\frac{m_{105}-m_{550}}{m_{105}-m_{0}} \times 100 \%$

waarin:

$w_{g v} \quad=$ gloeiverlies op basis van stoofdroge grond (\%);

$m_{0} \quad=$ massa van het lege kroesje $(\mathrm{g})$;

$m_{105}=$ massa van het kroesje met het stoofdroge monster $(\mathrm{g})$;

$m_{550}=$ massa van het kroesje met het gegloeide monster $(\mathrm{g})$.

Het organische stofgehalte is per definitie kleiner of gelijk aan het gloeiverlies. Het organische stofgehalte kan volgens de NEN 5754 bepaald worden door de gloeiverliesbepaling vergezeld te laten gaan van een lutumgehaltebepaling en een bepaling van het gehalte aan vrij ijzer. Het OS-gehalte wordt dan als volgt berekend:

$w_{O S}=w_{g v}-0.07 * L-0.12 * Y$

waarin:

$w_{O S} \quad=$ organisch stofgehalte van stoofdroge grond $(\%)$;

$L \quad=$ lutumgehalte $(\%)$;

$Y \quad=$ gehalte aan vrij ijzer (\%). (Alleen corrigeren bij $>5 \%$.)

\subsubsection{Retentie- en onverzadigde waterdoorlatendheidskarakteristiek}

De retentiekarakteristiek wordt bepaald met behulp van drie verschillende laboratoriumopstellingen:

- Zandbak voor het bereik $h=0$ tot $-100 \mathrm{~cm}(\mathrm{pF} \leq 2)$

- Verdampingsopstelling voor het bereik $h=-10$ tot $-700 \mathrm{~cm}(1 \leq \mathrm{pF} \leq 2,8)$

- Drukpanopstelling voor het bereik $h=-1000$ tot $h=-15000 \mathrm{~cm}(3 \leq \mathrm{pF} \leq 4,2)$

De karakteristiek voor de onverzadigde waterdoorlatendheid wordt bepaald met behulp van de verdampingsopstelling voor het bereik $h=-50$ tot $-700 \mathrm{~cm}(1,7 \leq \mathrm{pF} \leq 2,8)$. De metingen vinden plaats in het bodemhydrofysisch laboratorium van Wageningen UR onder strenge temperatuur- en vochtigheidscondities.

\subsubsection{Zandbakmethode}

Voor deze methode wordt een onverstoord gestoken grondmonster van $100 \mathrm{~cm}^{3}$ in een roestvrijstalen monsterring $(\mathrm{h}=5 \mathrm{~cm}, \mathrm{D} \approx 5 \mathrm{~cm})$ aan de boven- en onderzijde vlak afgewerkt. Op deze wijze ontstaat een monster met een nauwkeurig bekend grondvolume. Eén zijde wordt voorzien van een nylongaasje. Het monster wordt met water verzadigd en vervolgens met het nylongaasje op de 
zandbak geplaatst. De zandbak bevat een fijn gesorteerde grondsoort die een hoge doorlatendheid combineert met een kleine poriediameter. De drukhoogte van de grond in de bak zelf blijft in het te meten gebied, van $\mathrm{h}=0$ tot ongeveer $-100 \mathrm{~cm}$, nagenoeg verzadigd. Door middel van een drainagebuis onder in de bak die verbonden is met een waterreservoir, kan het bodemwater op elke gewenste zuigspanning worden gebracht. Door het monster in contact te brengen met deze zuigspanning, zal het water in het monster deze zuigspanning overnemen en zal er water uit het monster stromen (desorptie). Zodra na herhaaldelijk wegen geconcludeerd wordt dat er geen water meer uit het monster stroomt en het monster dus in evenwicht is met de aangelegde zuigspanning, wordt het monster definitief gewogen. Vervolgens wordt een nieuwe zuigspanning aangelegd en wordt de procedure herhaald. Zodra alle zuigspanningen op deze wijze zijn doorgemeten, wordt het monster gedroogd bij $105^{\circ} \mathrm{C}$ en wordt het opnieuw gewogen. Al het water is nu uit het monster verdwenen en de volumetrische vochtgehalten bij de aangelegde zuigspanningen kunnen worden berekend. De methode is beschreven in de ISO 11274 (1998).

\subsubsection{Verdampingsmethode}

De verdampingsmethode wordt gebruikt om een deel van de retentie- en onverzadigde waterdoorlatendheidskarakteristiek te bepalen. Voor deze methode (ISO 11275, 2004) wordt een onverstoord gestoken grondmonster van circa $600 \mathrm{~cm}^{3}$ in een PVC-monsterring $(\mathrm{h}=8 \mathrm{~cm}, \mathrm{D} \approx 10 \mathrm{~cm})$ aan de bovenen onderzijde vlak afgewerkt. Op deze wijze ontstaat een monster met een nauwkeurig bekend grondvolume. De onderzijde wordt afgesloten met een water- en luchtdichte bodemplaat. Het monster wordt met water verzadigd en vervolgens op een weegschaal geplaatst. Om verdamping mogelijk te maken, staat de bovenzijde bloot aan de omgevingslucht. De drukhoogte wordt op bekende tijdstippen in het monster gemeten met 4 tensiometers die op gelijke verticale afstanden worden geplaatst. Ook de tensiometerdoorgangen in de monsterring zijn lucht- en waterdicht afgesloten, zodat hierdoor geen verdamping kan optreden.

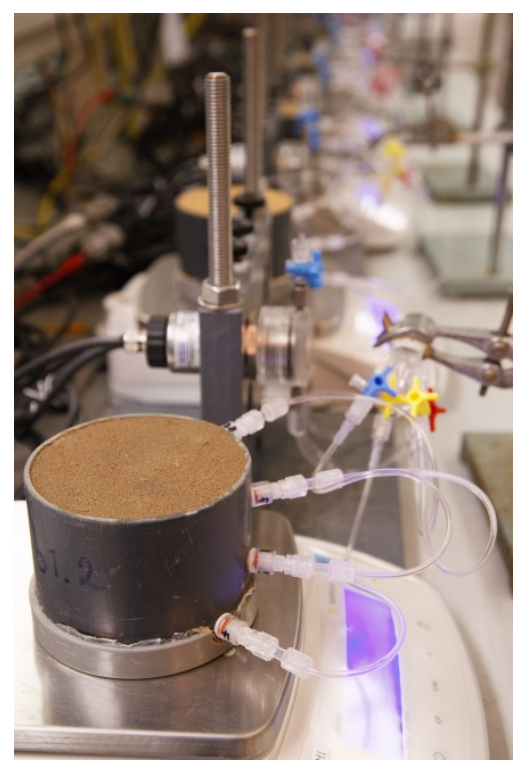

Figur 2.1 Verdampingsmethode.

Naast de drukhoogten bepaalt men op dezelfde tijdstippen het totale gewicht van het monster. Hieruit berekent men de afname van het totale watergehalte door verdamping. Zodra de water gevulde tensiometers stoppen met werken, meestal in de buurt van de $h=-700$ tot $-900 \mathrm{~cm}$, bepaalt men het ovendroge gewicht van het monster, zodat het gemiddelde watergehalte op elk tijdstip is terug te rekenen.

Tevens bepaalt men de gemiddelde gemeten drukhoogte. Dit resulteert in de gemeten retentiekarakteristiek. De retentiekarakteristiek gebruikt men om, volgens een iteratieve procedure, de vochtgehalten per tensiometerhoogte te bepalen op basis van de gemeten drukhoogten. De onverzadigde waterdoorlatendheid volgens Darcy kan nu berekend worden op basis van de 
verandering in watergehalte per tijdseenheid, de compartimenthoogte en de gradiënt van de stijghoogte in het monster. De data worden verkregen met een geautomatiseerde opstelling die door Wageningen UR in eigen beheer is ontwikkeld (zie Figuur 2.1).

\subsubsection{Drukpanmethode}

Met een hangende waterkolom, zoals aangebracht met de zandbakopstelling, kan een maximale theoretische zuigspanning van $1000 \mathrm{~cm}$ worden aangebracht. Vanaf dat punt zal het water gaan koken en is een betrouwbare meting niet meer mogelijk. Om toch bij grotere zuigspanningen te kunnen meten, wordt met een overdruk in plaats van een onderdruk gewerkt. Verschillende kleine verzadigde bodemmonsters worden op een met water verzadigde keramische plaat geplaatst. De keramische plaat wordt vervolgens in een drukpan gemonteerd. De keramische plaat is aan de onderzijde afgesloten met een rubbermat. Tussen de plaat en de mat bevindt zich water. Door de plaat zit een afvoerbuisje naar de bovenzijde van de plaat, dat met een slangetje naar een punt buiten de drukpan wordt geleid. De onderzijde van het afvoerbuisje bevindt zich tussen de rubbermat en het keramiek en is daarmee in staat water naar buiten af te voeren dat door de poriën van de keramische plaat wordt getransporteerd. Door middel van een overdruk in de drukpan wordt er een waterpotentiaal aangebracht tussen het water in het monster en de buitenlucht. De atmosferische druk wordt via een dunne slang overgebracht van buiten de drukpan naar de afgesloten onderzijde van de keramische plaat. Door de fijne poriestructuur van de plaat is de overdruk niet in staat om de poriën die gevuld zijn met water leeg te drukken. Wel kan er via de watergevulde poriën watertransport plaatsvinden vanuit het monster door de plaat en het slangetje naar buiten. Zodra het monster in evenwicht is met de aangelegde druk, wordt de druk weggenomen en worden de monsters gewogen. Daarna worden ze gedroogd bij $105^{\circ} \mathrm{C}$ en nogmaals gewogen. Om het volumetrisch vochtgehalte te kunnen bepalen, is dan wel nog de droge bulkdichtheid van een onverstoord monster nodig:

$\theta=\frac{\rho_{d}}{\rho_{l}} w$

waarin:

$\rho_{d} \quad=$ droge bulkdichtheid $\left(\mathrm{kg} \cdot \mathrm{m}^{-3}\right)$

$\rho_{l} \quad=$ dichtheid van water $\left(\mathrm{kg} \cdot \mathrm{m}^{-3}\right)$

$w \quad=$ watergehalte op gewichtsbasis en is gelijk het gewicht van het water in het monster gedeeld door het gewicht aan van de ovendroge grond $\left(\mathrm{kg}_{\mathrm{kg}} \mathrm{kg}^{-1}\right)$

Bij deze hoge zuigspanningen kunnen verstoorde grondmonsters worden gebruikt. De methode wordt gebruikt voor het meetbereik van $h=-1000$ tot $h=-15000 \mathrm{~cm}(3 \leq \mathrm{pF} \leq 4,2)$. De methode is beschreven in de ISO 11274 (1998).

\subsubsection{Verzadigde waterdoorlatendheid}

Een niet-verstoord, homogeen grondmonster in een ring wordt in een opstelling geplaatst. Het monster wordt geheel verzadigd met water. Boven op het grondmonster wordt een waterlaag met constante hoogte gehandhaafd. Bovendien wordt de onderzijde van het monster geheel verzadigd gehouden. Er wordt een constante stijghoogtegradiënt ingesteld door de uitstroomslang op een vaste positie te houden. Door de hoeveelheid uitstromend water per tijdseenheid te meten, kan de verzadigde waterdoorlatendheid $K_{s}$ volgens de wet van Darcy worden bepaald:

$k_{s}=\frac{V}{|\nabla H| \cdot \Delta t \cdot A}$

waarin:

$k_{s} \quad=$ verzadigde waterdoorlatendheid $\left(\mathrm{cm} \cdot \mathrm{d}^{-1}\right)$; ' $\mathrm{d}$ ' stelt een geheel etmaal voor

$V \quad=$ volume water dat gedurende $\Delta t$ is uitgestroomd $\left(\mathrm{cm}^{3}\right)$

$|\nabla H|=$ absolute hydraulische stijghoogtegradiënt $\left(\mathrm{cm} \cdot \mathrm{cm}^{-1}\right)$

$A=$ oppervlakte van het grondmonster $\left(\mathrm{cm}^{2}\right)$

$\Delta t \quad=$ tijd waarin het uitstromende water is gemeten (d) 
Voor de meting wordt afgeweken van de NEN 5789 (1991). De NEN gaat uit van vrije uitstroom aan de onderzijde van het monster. Omdat in dat geval onverzadigde delen aan de onderzijde van het monster ontstaan en de te overwinnen cohesie- en adhesiekrachten aan de onderzijde ongelijk aan nul zijn, is de gemeten waterdoorlatendheid lager dan de werkelijke verzadigde waterdoorlatendheid. Door de onderzijde verzadigd te houden, wordt dit probleem ondervangen (Vos et al. 1997).

\subsubsection{Karakteristiek-parametrisering met Mualem-Van Genuchten}

\subsubsection{Gangbare methode: MvG-concept}

De metingen van de drukhoogten, vochtgehalten en tijd van de verschillende meetmethoden en de verzadigde waterdoorlatendheden zijn gebruikt om de retentie- en onverzadigde waterdoorlatendheidskarakteristiek te bepalen. Daarbij is in dit project gebruikgemaakt van het Mualem-Van Genuchtenmodel (Mualem, 1976; Van Genuchten, 1980). Voor het uitvoeren van de berekeningen en fitprocedure is in dit project een filter en een Excelrekensheet ontwikkeld. In het lab wordt met zeer korte tijdsintervallen gemeten, zodat verstoringen en temperatuurinvloeden duidelijker zichtbaar worden. Dit resulteert echter in grote databestanden. Het is daarom wenselijk het aantal datapunten te ontdoen van ruis en te reduceren voorafgaand aan verdere verwerking. Omdat kleine schommelingen in de data (ruis, of temperatuurinvloeden) tot grote afwijkingen kunnen zorgen in de afgeleide data (met name de onverzadigde waterdoorlatendheid in het natte traject), is een filter ontwikkeld waarmee de meetset gereduceerd wordt tot een kleinere set met essentiële data. Er worden geen data aangepast, alleen selectief volgens een vast protocol weggelaten. Vervolgens wordt deze gereduceerde dataset gebruikt in het nieuw ontwikkelde Excelrekensheet dat op strategische momenten gebruikmaakt van het RETC-programma (Van Genuchten et al. 1991; Leij et al. 1992). Het grote voordeel van de gevolgde werkwijze is dat de fitprocedure op een veel kleiner detailniveau geanalyseerd kan worden. Te denken valt daarbij aan uitbijters of berekende en gemeten gewichtsafnamen in de tijd. Vooral de prefit-fase, waarin de puntenwolk van de onverzadigde doorlatendheid wordt afgeleid, moet altijd kritisch door een expert worden beschouwd, omdat met name in het natte traject door modellering fouten kunnen ontstaan in de afgeleide gegevens vanwege beperkingen van het model en meetnauwkeurigheid. Het filter voorkomt voor een groot deel afwijkingen in het natte traject. Bijlage 1 geeft een uitgebreidere weergave van het Excelrekenprogramma.

\subsubsection{Toekomstige methode: PDI-concept}

Voor het droge traject hebben Peters (2013) en Iden \& Durner (2014) recentelijk de volgende aanpassingen voorgesteld, bekend onder de naam PDI-concept (Peters, Durner, Iden). Hierbij wordt de waterretentiecurve geschreven als de som van een capillaire en een adsorptiebijdrage. Er wordt rekening gehouden met enerzijds de lucht-intreewaarde en met het feit dat het vochtgehalte gelijk aan nul is bij een drukhoogte die heerst in een ovendroog $\left(105^{\circ} \mathrm{C}\right)$ monster: de $\log (h)$ is dan ongeveer 6,8 à 7,0. Hiermee verdwijnt in principe het asymptotische gedrag $\left(\theta_{r}\right)$ dat standaard in de Van Genuchten-relatie zit. Voor de doorlatendheid wordt rekening gehouden met een capillaire bijdrage, een bijdrage via transport in dunne waterfilmpjes en optioneel met een bijdrage van damptransport. Hierbij wordt meestal een golvend gedrag verkregen in de relatie $K(h)$ waarbij beide grootheden op een log-schaal worden geplot. Dat stemt overeen met waarnemingen zoals verkregen met de verdampingsmethode, in tegenstelling tot de rechte lijn op log-log schaal van de Mualemvergelijking (1976) in het droge traject. Met name de beschrijving van de $K(h)$ relatie kan sterk verbeterd worden door niet de standaard Van Genuchten-Mualem-relaties te beschouwen, maar een bimodale PDI-variant, ofwel een aangevulde Van Genuchten-Mualem-relatie, te kiezen. De krommingen in de $K(h)$ data kunnen dan beter beschreven worden en de $\theta(h)$-relatie snijdt de $x$-as. Alleen uit oogpunt van standaardisatie en het standaardgebruik van Mualem-van Genuchtenparameters in huidige modellen, is de PDI nog niet geëffectueerd binnen BRO en BIS. In het kader van innovatie en voortschrijdend inzicht ligt het echter wel in de lijn der verwachting dat het PDI-concept in de nabije toekomst geïmplementeerd gaat worden. 


\subsubsection{Prefit - De eerste Van Genuchten-retentiefit}

De metingen van de drukhoogten en gemiddelde volumetrische vochtgehalten van de ruwe meetdata van de verdampingsmethode worden gebruikt om de Van Genuchten-retentiecurve voor de eerste keer te fitten. Deze gemiddelde fit wordt gebruikt om vochtgehalten te berekenen in elk compartiment van het bodemmonster, ofwel op elke hoogte van de tensiometers, en op elk tijdstip. Door de berekende vochtgehalten per compartiment te vermenigvuldigen met het volume van het monstercompartiment, ontstaat een berekende hoeveelheid water per compartiment. De som van deze hoeveelheden water moet gelijk zijn aan de totale gemeten hoeveelheid water in het monster. Als hierin een afwijking zit, worden de vochtgehalten van de retentiecurve aangepast. Op deze wijze wordt de fit door iteratie geoptimaliseerd. De prefits in dit project zijn, afhankelijk van de resultaten, uitgevoerd met een 1, 2 of 3 modale functie van Van Genuchten (Durner, 1992).

De geoptimaliseerde prefit wordt vervolgens gebruikt om de waterbeweging tussen de 4 bodemlagen in de tijd te berekenen. Met de vergelijking van Darcy worden vervolgens voor elke set van 2 tensiometers de doorlatendheden als functie van de drukhoogte berekend, resulterend in 3 datasets van 3 tensiometerparen. Deze methode is gebaseerd op de zogenaamde 'instantaneous profile method' en is bijvoorbeeld beschreven in Peters and Durner (2008). In het natte bereik kunnen in de praktijk door kleine meetfouten $d h / d z$-waarden, die dicht bij de waarde 1 liggen, resulteren in negatieve waarden van $k$, of in waarden die grote uitschieters vertonen. Met het filter worden deze problemen grotendeels ondervangen. Mochten er toch nog dergelijke fouten optreden, dan worden deze waarden in dit project als uitbijters beschouwd en niet meegenomen in de verdere analyse. In de literatuur wordt in deze context veelvuldig gewezen op de onzekere uitkomsten van $k$ - $h$-relaties in het natte gebied. Afhankelijk van de grondsoort is het in de praktijk daarom lastig om betrouwbare $k-h-$ relaties te vinden in het gebied $h=0$ tot $-50 \mathrm{~cm}$. Er zal daarom niet altijd een meting van de doorlatendheid berekend kunnen worden in het gebied $h=0$ tot $-10 \mathrm{~cm}$. Hoewel kwaliteitsstatus A dit wel vereist, zijn de data wel opgenomen in BIS, maar is hiervan een melding gemaakt in het commentaarveld. Via aanvullende methoden zijn bepalingen van doorlatendheden in dit natte traject wel mogelijk, zoals via de sproeimethode of de druppel-infiltrometer, maar daar waren in dit project geen middelen voor beschikbaar.

\subsubsection{Uiteindelijke Mualem-van Genuchten-fit}

Samen met de metingen uit de zandbak-, drukpan- en verzadigde waterdoorlatendheidsmethode, worden de retentie- en 3-series met onverzadigde waterdoorlatendheidsdata uit de prefit gebruikt om de uiteindelijke Mualem-van Genuchten-fit uit te voeren. De uiteindelijke Van Genuchten pF-curve kan afwijken van de prefit pF-curve, omdat de uiteindelijke fit geoptimaliseerd is in combinatie met de doorlatendheidsdata, terwijl de prefit alleen gebaseerd is op vochtgehalten en drukhoogten. Bovendien is de uiteindelijke fit een 1-modale fit, terwijl de prefit vaak een hogere modaliteit heeft. 
In dit hoofdstuk wordt een overzicht gegeven van de resultaten. Daarbij is een indeling gehanteerd die aansluit bij de in hoofdstuk 2 weergegeven opschalingseenheden. De resultaten worden weergegeven op monsterniveau en in twee categorieën ingedeeld:

I Nieuwe monsters (118 stuks) genomen en geanalyseerd in de periode 2012-2016 die tezamen met profielbeschrijvingen en metagegevens fysiek zijn ondergebracht in BIS.

II Bestaande monsters in Priapus, waarvan:

- de afgeleide gegevens en eventuele aanvullende gegevens met hoge kwaliteit van 44 bestaande monsters in Priapus zijn ondergebracht in BIS en daar fysiek zijn gekoppeld aan bestaande profielbeschrijvingen van BIS. Het betreft hier ten minste de afgeleide doorlatendheiddrukhoogte-vochtgehalte-relaties, maar meestal ook textuur en organische stofgegevens. Van deze Priapus-monsters zijn de ruwe meetgegevens niet altijd aanwezig.

- de afgeleide gegevens van 10 Priapus-monsters oorspronkelijk als onvoldoende waren gekwalificeerd. De afgeleide gegevens zijn met de nieuwe software opnieuw doorgerekend en voldoen alsnog aan de gestelde criteria. Ze zijn tezamen met eventueel overig beschikbare meetgegevens en bestaande profielbeschrijvingen in BIS opgenomen.

- in Priapus en BIS geen profielbeschrijvingen en metagegevens aanwezig zijn, maar waarvan wel literatuur is gevonden met metagegevens (53 stuks). In de tabel is de koppeling gelegd tussen de monsters in Priapus en de betreffende literatuur, zodat het overbrengen van de gecombineerde data naar BIS makkelijker kan worden uitgevoerd.

In Tabel 6 is een overzicht gegeven van de koppeling tussen de opschalingseenheden van Tabel 4 en de nieuwe monsternummers. Omdat, ondanks de strenge criteria voor de bepaling van de monsterlocaties (paragraaf 2.2.2), niet altijd exact de verwachte opschalingseenheden zijn aangetroffen, zijn sommige monsters ondergebracht in de werkelijk aangetroffen eenheden.

Tabel 6 Referentietabel met differentiatiemogelijkheden en de daarin beschikbare monsters.

\begin{tabular}{|c|c|c|c|c|c|c|c|}
\hline $\begin{array}{c}\text { Afzettings- } \\
\text { milieu }\end{array}$ & $\begin{array}{l}\text { Textuur- } \\
\text { klasse }^{\text {b) }}\end{array}$ & 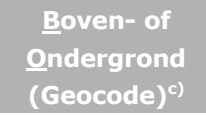 & MIN a) & $\begin{array}{l}\text { Monster- } \\
\text { naam }\end{array}$ & $\begin{array}{c}\text { Monster- } \\
\text { name- } \\
\text { datum }\end{array}$ & $\begin{array}{l}\text { X-coör- } \\
\text { dinaat } \\
(\mathrm{m})\end{array}$ & $\begin{array}{l}\text { Y-coör- } \\
\text { dinaat } \\
\text { (m) }\end{array}$ \\
\hline \multirow{3}{*}{$\begin{array}{l}\text { Glaciale en } \\
\text { fluvio-glaciale } \\
\text { afzettingen }\end{array}$} & \multirow{3}{*}{ keileem } & B (500) & 10059,10060 & Ens11 & $26-6-2013$ & 259885 & 467940 \\
\hline & & \multirow{2}{*}{0} & 10061,10062 & Ens12 & $26-6-2013$ & 259885 & 467940 \\
\hline & & & 10063,10064 & $\mathrm{HoO} 2$ & $27-6-2013$ & 232493 & 549592 \\
\hline \multirow{7}{*}{$\begin{array}{l}\text { Textuur } \\
\text { eolische en } \\
\text { sommige } \\
\text { niet-eolische } \\
\text { afzettingen: } \\
\text { leemgehalte }\end{array}$} & \multirow{5}{*}{$\begin{array}{c}\text { Zeer } \\
\text { sterk } \\
\text { lemig } \\
\text { zand }\end{array}$} & \multirow{2}{*}{ B } & 10079,10080 & Wou11 & $16-4-2014$ & 86475 & 394400 \\
\hline & & & 10087,10088 & Raa11 & $14-5-2014$ & 218895 & 493210 \\
\hline & & \multirow{3}{*}{$\mathrm{O}$} & 10081,10082 & Wou12 & $16-4-2014$ & 86475 & 394400 \\
\hline & & & 10089,10090 & Raa12 & $14-5-2014$ & 218895 & 493210 \\
\hline & & & 10077,10078 & Rhe2 & 3-4-2014 & 198965 & 448105 \\
\hline & \multirow{2}{*}{$\begin{array}{c}\text { Zandige } \\
\text { leem }\end{array}$} & B & 10073,10074 & Gro11 & $3-4-2014$ & 194130 & 423304 \\
\hline & & 0 & 10075,10076 & Gro12 & $3-4-2014$ & 194130 & 423304 \\
\hline \multirow{11}{*}{$\begin{array}{c}\text { Textuur } \\
\text { eolische en } \\
\text { sommige } \\
\text { niet-eolische } \\
\text { afzettingen: } \\
\text { M50 } \\
\text { zandfractie }\end{array}$} & $\begin{array}{c}\text { Uiterst } \\
\text { fijn zand }\end{array}$ & $\begin{array}{c}\text { B } \\
\text { Marien (200) }\end{array}$ & 10067,10068 & Blo1N & $4-9-2013$ & 192200 & 526690 \\
\hline & \multirow{3}{*}{$\begin{array}{l}\text { Zeer fijn } \\
\text { zand }\end{array}$} & B & 10101,10102 & Lar1kop & $9-5-2016$ & 226120 & 467695 \\
\hline & & Eolisch (400) & 10107 & Lar2mid & $9-5-2016$ & 226120 & 467695 \\
\hline & & $\begin{array}{c}\text { O } \\
\text { Eolisch (400) }\end{array}$ & 10108 & Lar2mid & $9-5-2016$ & 226120 & 467695 \\
\hline & \multirow{3}{*}{$\begin{array}{l}\text { Matig fijn } \\
\text { zand }\end{array}$} & B & 10037,10038 & Luy11 & $17-6-2013$ & 150486 & 365497 \\
\hline & & Eolisch (400) & 10109,10110 & Lar3 & $3-6-2016$ & 226233 & 467924 \\
\hline & & $\begin{array}{c}\text { O } \\
\text { Eolisch (400) }\end{array}$ & $\begin{array}{l}10103,10104 \\
10105,10106\end{array}$ & Lar1kop & $9-5-2016$ & 226120 & 467695 \\
\hline & \multirow{4}{*}{$\begin{array}{c}\text { Matig } \\
\text { grof zand }\end{array}$} & 0 & 10045,10046 & Rog1 & $16-7-2013$ & 183900 & 508200 \\
\hline & & Marien (200) & 10051,10052 & Ber1N & $10-7-2013$ & 106130 & 520320 \\
\hline & & 0 & 10039,10040 & Luy12 & $17-6-2013$ & 150486 & 365497 \\
\hline & & Fluviatiel (300) & 10053,10054 & Rek1N & $12-7-2013$ & 248429 & 459637 \\
\hline
\end{tabular}




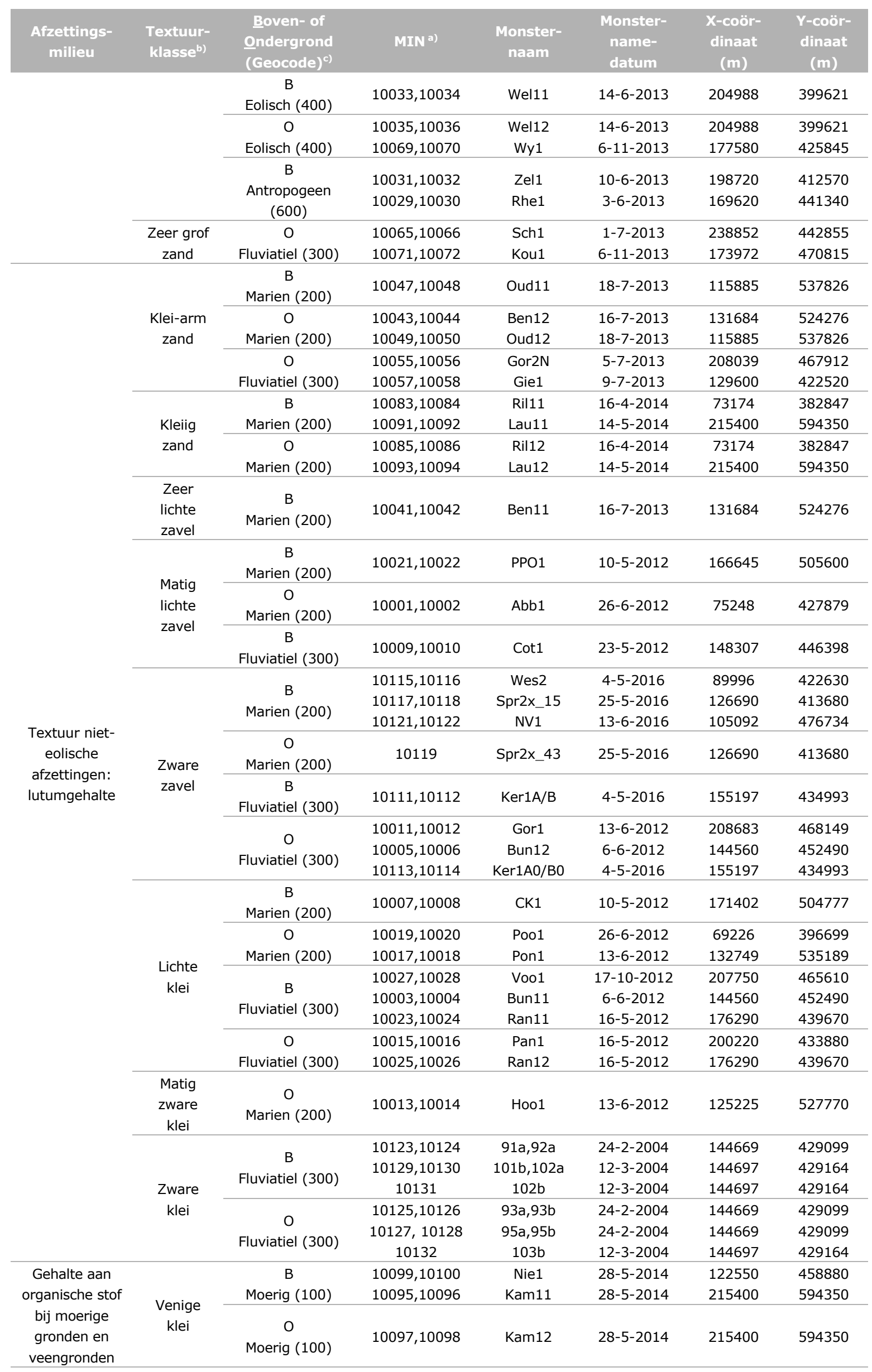

a) MIN = Monster Identificatie Nummer.

b) Indeling gebaseerd op veldwaarneming (profielbeschrijving); deze kan soms afwijken van de gemeten textuur en OS-gehalten.

c) Code voor afzettingsmilieu of ontwikkelingswijze van de horizont (zie Bijlage 3). 


\section{$3.1 \quad$ Veldgegevens}

In Tabel 7 zijn enkele belangrijke veldgegevens weergegeven, zoals monsterdiepte, standaardpuntencode, grondwatertrap en grondwaterstanden (GHG en GLG). Meer gedetailleerde gegevens zijn terug te vinden in de database zelf.

Tabel 7 Monsterdiepte, profielgegevens volgens de standaardpuntencode, grondwatertrapcodering en de gemiddeld hoogste en laagste grondwaterstand op basis van de veldwaarnemingen; alles in $\mathrm{cm}$ ten opzichte van maaiveld.

\begin{tabular}{|c|c|c|c|c|c|c|}
\hline MIN a) & $\begin{array}{c}\text { Bovenkant } \\
\text { monster } \\
\text { (cm-MV) }\end{array}$ & $\begin{array}{c}\text { Onderkant } \\
\text { monster } \\
\text { (cm-MV) }\end{array}$ & $\begin{array}{l}\text { Standaard- } \\
\text { puntencode }\end{array}$ & Gt & $\begin{array}{c}\text { GHG } \\
\text { (cm-MV) }\end{array}$ & $\begin{array}{c}\text { GLG } \\
(\mathrm{cm}-\mathrm{MV})\end{array}$ \\
\hline 10001 & 40 & 50 & M5p235a & VIIo & 90 & 140 \\
\hline 10002 & 40 & 50 & M5p235a & VIIo & 90 & 140 \\
\hline 10003 & 5 & 15 & $\mathrm{R} 5 \times 315 \mathrm{c}$ & VIo & 70 & 150 \\
\hline 10004 & 5 & 15 & $\mathrm{R} 5 \times 315 \mathrm{c}$ & VIo & 70 & 150 \\
\hline 10005 & 45 & 55 & $\mathrm{R} 5 \times 315 \mathrm{c}$ & VIo & 70 & 150 \\
\hline 10006 & 45 & 55 & $R 5 \times 315 c$ & VIo & 70 & 150 \\
\hline 10007 & 5 & 15 & M5p315a & VIIo & 90 & 150 \\
\hline 10008 & 5 & 15 & M5p315a & VIIo & 90 & 150 \\
\hline 10009 & 10 & 20 & R5x235a & VIId & 100 & 200 \\
\hline 10010 & 10 & 20 & $\mathrm{R} 5 \times 235 \mathrm{a}$ & VIId & 100 & 200 \\
\hline 10011 & 40 & 50 & R5x232a & VIIId & 160 & 260 \\
\hline 10012 & 40 & 50 & $\mathrm{R} 5 \times 232 \mathrm{a}$ & VIIId & 160 & 260 \\
\hline 10013 & 60 & 70 & M5p235c/H & VIo & 60 & 160 \\
\hline 10014 & 60 & 70 & M5p235c/H & VIo & 60 & 160 \\
\hline 10015 & 30 & 40 & R5×315a & VIo & 60 & 160 \\
\hline 10016 & 30 & 40 & $\mathrm{R} 5 \times 315 \mathrm{a}$ & VIo & 60 & 160 \\
\hline 10017 & 50 & 60 & M5p235a & VIIo & 90 & 140 \\
\hline 10018 & 50 & 60 & M5p235a & VIIo & 90 & 140 \\
\hline 10019 & 35 & 45 & M5m311c & VIo & 50 & 120 \\
\hline 10020 & 35 & 45 & M5m311c & VIo & 50 & 120 \\
\hline 10021 & 5 & 15 & M5p235a & VIIo & 90 & 150 \\
\hline 10022 & 5 & 15 & M5p235a & VIIo & 90 & 150 \\
\hline 10023 & 10 & 20 & R5p235cp 10 & VIo & 70 & 170 \\
\hline 10024 & 10 & 20 & R5p235cp10 & VIo & 70 & 170 \\
\hline 10025 & 40 & 50 & R5p235cp10 & VIo & 70 & 170 \\
\hline 10026 & 40 & 50 & R5p235cp10 & VIo & 70 & 170 \\
\hline 10027 & 5 & 15 & R5p315b & VId & 70 & 190 \\
\hline 10028 & 5 & 15 & R5p315b & VId & 70 & 190 \\
\hline 10029 & 5 & 15 & $4 s 512$ & VIIId & 300 & 400 \\
\hline 10030 & 5 & 15 & $4 s 512$ & VIIId & 300 & 400 \\
\hline 10031 & 25 & 35 & $4 r 513$ & VIId & 120 & 200 \\
\hline 10032 & 25 & 35 & $4 r 513$ & VIId & 120 & 200 \\
\hline 10033 & 20 & 30 & $2 d 512$ & VIo & 75 & 170 \\
\hline 10034 & 20 & 30 & $2 \mathrm{~d} 512$ & VIo & 75 & 170 \\
\hline 10035 & 65 & 75 & $2 d 512$ & VIo & 75 & 170 \\
\hline 10036 & 65 & 75 & $2 \mathrm{~d} 512$ & VIo & 75 & 170 \\
\hline 10037 & 10 & 20 & $4 \mathrm{i} 432$ & VIo & 65 & 170 \\
\hline 10038 & 10 & 20 & $4 i 432$ & VIo & 65 & 170 \\
\hline 10039 & 35 & 45 & $4 i 432$ & VIo & 65 & 170 \\
\hline 10040 & 35 & 45 & $4 i 432$ & VIo & 65 & 170 \\
\hline 10041 & 10 & 20 & $\mathrm{k} 4 \mathrm{k} 4111 \mathrm{a}$ & VIo & 45 & 130 \\
\hline 10042 & 10 & 20 & $\mathrm{k} 4 \mathrm{k} 4111 \mathrm{a}$ & VIo & 45 & 130 \\
\hline 10043 & 45 & 55 & k4k4111a & VIo & 45 & 130 \\
\hline 10044 & 45 & 55 & k4k4111a & VIo & 45 & 130 \\
\hline 10045 & 60 & 70 & $5 \mathrm{k} 4211 \mathrm{a} / \mathrm{F}$ & Vbo & 30 & 130 \\
\hline 10046 & 60 & 70 & $5 \mathrm{k} 4211 \mathrm{a} / \mathrm{F}$ & Vbo & 30 & 130 \\
\hline 10047 & 30 & 40 & $4 \mathrm{k} 4311 \mathrm{c} / \mathrm{H}$ & IVu & 45 & 120 \\
\hline 10048 & 30 & 40 & $4 \mathrm{k} 4311 \mathrm{c} / \mathrm{H}$ & IVu & 45 & 120 \\
\hline 10049 & 55 & 65 & $4 \mathrm{k} 4311 \mathrm{c} / \mathrm{H}$ & IVu & 45 & 120 \\
\hline
\end{tabular}




\begin{tabular}{|c|c|c|c|c|c|c|}
\hline MIN a) & $\begin{array}{c}\text { Bovenkant } \\
\text { monster } \\
\text { (cm-MV) }\end{array}$ & $\begin{array}{c}\text { Onderkant } \\
\text { monster } \\
\text { (cm-MV) }\end{array}$ & $\begin{array}{l}\text { Standaard- } \\
\text { puntencode }\end{array}$ & Gt & $\begin{array}{c}\text { GHG } \\
(\mathrm{cm}-\mathrm{MV})\end{array}$ & $\begin{array}{c}\text { GLG } \\
(\mathrm{cm}-\mathrm{MV})\end{array}$ \\
\hline 10050 & 55 & 65 & $4 \mathrm{k} 4311 \mathrm{c} / \mathrm{H}$ & IVu & 45 & 120 \\
\hline 10051 & 60 & 70 & $5 \mathrm{k} 511$ & VIId & 115 & 220 \\
\hline 10052 & 60 & 70 & $5 \mathrm{k} 511$ & VIId & 115 & 220 \\
\hline 10053 & 70 & 80 & $4 i 512$ & VIo & 60 & 150 \\
\hline 10054 & 70 & 80 & $4 i 512$ & VIo & 60 & 150 \\
\hline 10055 & 45 & 55 & $\mathrm{R} 5 \times 235 \mathrm{c}$ & VIId & 90 & 200 \\
\hline 10056 & 45 & 55 & $\mathrm{R} 5 \times 235 \mathrm{c}$ & VIId & 90 & 200 \\
\hline 10057 & 50 & 60 & $\mathrm{R} 5 \times 222 \mathrm{c}$ & VIId & 90 & 190 \\
\hline 10058 & 50 & 60 & $\mathrm{R} 5 \times 222 \mathrm{c}$ & VIId & 90 & 190 \\
\hline 10059 & 5 & 15 & mK4p225cg14 & Vad & 20 & 300 \\
\hline 10060 & 5 & 15 & $\mathrm{mK} 4 \mathrm{p} 225 \mathrm{cg} 14$ & Vad & 20 & 300 \\
\hline 10061 & 40 & 50 & mK4p225cg14 & Vad & 20 & 300 \\
\hline 10062 & 40 & 50 & $\mathrm{mK} 4 \mathrm{p} 225 \mathrm{cg} 14$ & Vad & 20 & 300 \\
\hline 10063 & 35 & 45 & $\mathrm{~K} 5 \mathrm{p} 215 \mathrm{c}$ & Vad & 20 & 300 \\
\hline 10064 & 35 & 45 & K5p215c & Vad & 20 & 300 \\
\hline 10065 & 30 & 40 & 4k512 & VId & 70 & 200 \\
\hline 10066 & 30 & 40 & $4 \mathrm{k} 512$ & VId & 70 & 200 \\
\hline 10067 & 10 & 20 & $5 \mathrm{k} 4111 \mathrm{a}$ & VIId & 100 & 230 \\
\hline 10068 & 10 & 20 & $5 \mathrm{k} 4111 \mathrm{a}$ & VIId & 100 & 230 \\
\hline 10069 & 90 & 100 & 4s511 & VIIId & 150 & 250 \\
\hline 10070 & 90 & 100 & $4 s 511$ & VIIId & 150 & 250 \\
\hline 10071 & 70 & 80 & $2 i 511$ & VIIId & 500 & 600 \\
\hline 10072 & 70 & 80 & $2 i 511$ & VIIId & 500 & 600 \\
\hline 10073 & 15 & 25 & $5 \times 81$ & VIIId & 0 & 0 \\
\hline 10074 & 15 & 25 & $5 \times 81$ & VIIId & 0 & 0 \\
\hline 10075 & 50 & 60 & $5 \times 81$ & VIIId & 0 & 0 \\
\hline 10076 & 50 & 60 & $5 \times 81$ & VIIId & 0 & 0 \\
\hline 10077 & 45 & 55 & $5 \times 81$ & VIIId & 0 & 0 \\
\hline 10078 & 45 & 55 & $5 \times 81$ & VIIId & 0 & 0 \\
\hline 10079 & 10 & 20 & $4 s 424$ & VIIo & 85 & 180 \\
\hline 10080 & 10 & 20 & $4 s 424$ & VIIo & 85 & 180 \\
\hline 10081 & 55 & 65 & $4 s 424$ & VIIo & 85 & 180 \\
\hline 10082 & 55 & 65 & $4 s 424$ & VIIo & 85 & 180 \\
\hline 10083 & 10 & 20 & $5 \mathrm{k} 4212 \mathrm{a}$ & VIIo & 85 & 130 \\
\hline 10084 & 10 & 20 & $5 \mathrm{k} 4212 \mathrm{a}$ & VIIo & 85 & 130 \\
\hline 10085 & 40 & 50 & $5 \mathrm{k} 4212 \mathrm{a}$ & VIIo & 85 & 130 \\
\hline 10086 & 40 & 50 & $5 \mathrm{k} 4212 \mathrm{a}$ & VIIo & 85 & 130 \\
\hline 10087 & 15 & 25 & $2 q 424$ & Vbo & 35 & 160 \\
\hline 10088 & 15 & 25 & $2 q 424$ & Vbo & 35 & 160 \\
\hline 10089 & 35 & 45 & $2 q 424$ & Vbo & 35 & 160 \\
\hline 10090 & 35 & 45 & $2 q 424$ & Vbo & 35 & 160 \\
\hline 10091 & 10 & 20 & $5 \mathrm{k} 4212 \mathrm{a}$ & VIIo & 85 & 130 \\
\hline 10092 & 10 & 20 & $5 \mathrm{k} 4212 \mathrm{a}$ & VIIo & 85 & 130 \\
\hline 10093 & 35 & 45 & $5 \mathrm{k} 4212 \mathrm{a}$ & VIIo & 85 & 130 \\
\hline 10094 & 35 & 45 & $5 \mathrm{k} 4212 \mathrm{a}$ & VIIo & 85 & 130 \\
\hline 10095 & 5 & 15 & $\mathrm{R} 4 \mathrm{~m} 311 \mathrm{c}$ & IIIb & 30 & 90 \\
\hline 10096 & 5 & 15 & $\mathrm{R} 4 \mathrm{~m} 311 \mathrm{c}$ & IIIb & 30 & 90 \\
\hline 10097 & 35 & 45 & $\mathrm{R} 4 \mathrm{~m} 311 \mathrm{c}$ & IIIb & 30 & 90 \\
\hline 10098 & 35 & 45 & $\mathrm{R} 4 \mathrm{~m} 311 \mathrm{c}$ & IIIb & 30 & 90 \\
\hline 10099 & 5 & 15 & v4c32I4 & IIb & 25 & 75 \\
\hline 10100 & 5 & 15 & v4c3214 & IIb & 25 & 75 \\
\hline 10101 & 5 & 15 & $2 r 422$ & VIo & 70 & 160 \\
\hline 10102 & 5 & 15 & $2 r 422$ & VIo & 70 & 160 \\
\hline 10103 & 35 & 45 & $2 r 422$ & VIo & 70 & 160 \\
\hline 10104 & 35 & 45 & $2 r 422$ & VIo & 70 & 160 \\
\hline 10105 & 60 & 70 & $2 r 422$ & VIo & 70 & 160 \\
\hline 10106 & 60 & 70 & $2 r 422$ & VIo & 70 & 160 \\
\hline 10107 & 35 & 45 & $2 q 423$ & VIo & 60 & 150 \\
\hline 10108 & 60 & 70 & $2 q 423$ & VIo & 60 & 150 \\
\hline 10109 & 33 & 43 & $2 r 432$ & VIo & 60 & 130 \\
\hline 10110 & 33 & 43 & 2 r432 & VIo & 60 & 130 \\
\hline 10111 & 16 & 26 & R5p235c & VIo & 75 & 160 \\
\hline
\end{tabular}




\begin{tabular}{|c|c|c|c|c|c|c|}
\hline MIN a) & $\begin{array}{c}\text { Bovenkant } \\
\text { monster } \\
\text { (cm-MV) }\end{array}$ & $\begin{array}{c}\text { Onderkant } \\
\text { monster } \\
\text { (cm-MV) }\end{array}$ & $\begin{array}{l}\text { Standaard- } \\
\text { puntencode }\end{array}$ & $\mathrm{Gt}$ & $\begin{array}{c}\text { GHG } \\
(\mathrm{cm}-\mathrm{MV})\end{array}$ & $\begin{array}{c}\text { GLG } \\
(\mathrm{cm}-\mathrm{MV})\end{array}$ \\
\hline 10112 & 16 & 26 & R5p235c & VIo & 75 & 160 \\
\hline 10113 & 50 & 60 & R5p235c & VIo & 75 & 160 \\
\hline 10116 & 12 & 22 & M5p235a & VIo & 60 & 160 \\
\hline 10117 & 15 & 25 & M5p235a & IVu & 60 & 110 \\
\hline 10118 & 15 & 25 & M5p235a & IVu & 60 & 110 \\
\hline 10119 & 43 & 53 & M5p235a & IVu & 60 & 110 \\
\hline 10123 & 7 & 17 & R5p334c & P.M. & P.M. & P.M. \\
\hline 10124 & 37 & 47 & R5p334c & P.M. & P.M. & P.M. \\
\hline 10125 & 60 & 75 & R5p334c & P.M. & P.M. & P.M. \\
\hline 10126 & 60 & 75 & R5p334c & P.M. & P.M. & P.M. \\
\hline 10127 & 140 & 155 & R5p334c & P.M. & P.M. & P.M. \\
\hline 10128 & 140 & 155 & R5p334c & P.M. & P.M. & P.M. \\
\hline 10129 & 7 & 17 & R5p334c & Vao & 20 & 130 \\
\hline 10130 & 35 & 45 & R5p334c & Vao & 20 & 130 \\
\hline 10131 & 35 & 45 & R5p334c & Vao & 20 & 130 \\
\hline 10132 & 65 & 75 & R5p334c & Vao & 20 & 130 \\
\hline
\end{tabular}

a) MIN = Monster Identificatie Nummer.

Gt = Grondwatertrap; GHG = Gemiddeld Hoogste Grondwaterstand; GLG = Gemiddeld Laagste Grondwaterstand 


\subsection{Textuur}

In Tabel 8 zijn de gemeten textuurgegevens weergegeven. Kleine negatieve waarden in de tabel duiden op een fractie die lager is dan de aantoonbaarheidsgrens van circa $1 \%$. Verder zijn er enkele bodemmonsters aanwezig, waarvan de fracties < $63 \mu \mathrm{m}$ niet volgens de geldende NEN- en ISOnormen geanalyseerd konden worden. Daarvan is in het onderschrift van de tabel melding gemaakt.

Tabel 8 Textuurgegevens in gewichtsprocenten van de minerale fractie kleiner dan $2000 \mu \mathrm{m}$.

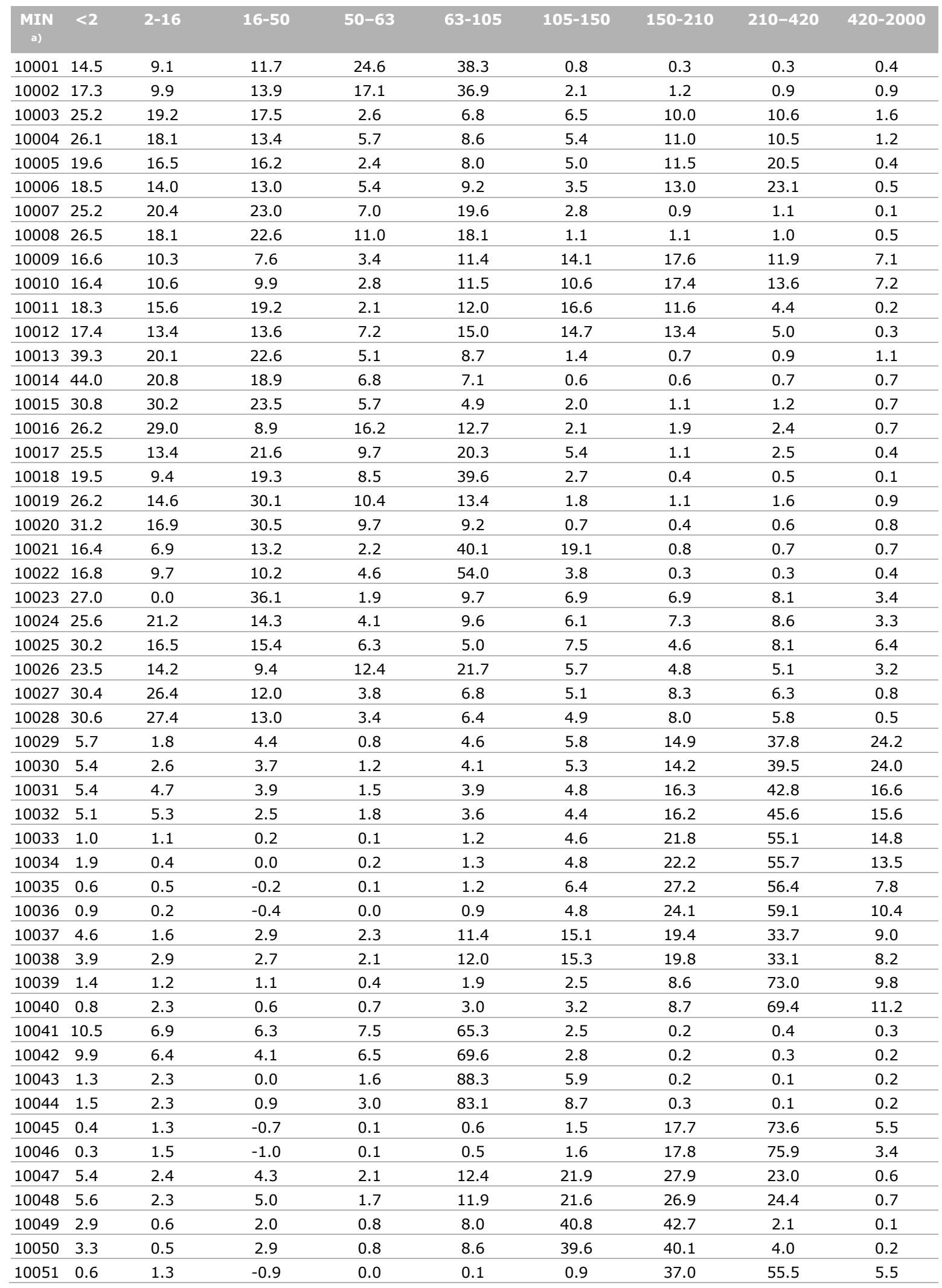




\begin{tabular}{|c|c|c|c|c|c|c|c|c|c|}
\hline $\begin{array}{l}\text { MIN } \\
\text { a) }\end{array}$ & $<2$ & 2-16 & $16-50$ & $50-63$ & 63-105 & $105-150$ & $150-210$ & $210-420$ & $420-2000$ \\
\hline 10052 & 0.2 & 1.2 & -1.0 & 0.0 & 0.1 & 0.9 & 36.0 & 56.2 & 6.4 \\
\hline 10053 & 0.7 & 0.8 & -0.4 & 0.0 & 0.9 & 3.8 & 12.8 & 37.5 & 43.9 \\
\hline 10054 & 0.3 & 1.7 & -0.9 & 0.1 & 1.0 & 4.4 & 15.6 & 43.4 & 34.4 \\
\hline 10055 & 4.3 & 1.7 & 2.1 & 0.8 & 8.5 & 13.9 & 33.4 & 34.4 & 0.9 \\
\hline 10056 & 2.9 & 1.3 & 2.0 & 0.4 & 6.2 & 11.2 & 29.0 & 45.4 & 1.7 \\
\hline 10057 & 2.5 & 1.3 & 1.8 & 0.4 & 4.5 & 16.3 & 46.8 & 25.6 & 0.8 \\
\hline 10058 & 1.9 & 0.7 & 0.5 & 0.2 & 4.7 & 17.3 & 50.3 & 23.8 & 0.5 \\
\hline 10059 & 7.4 & 5.1 & 6.1 & 2.9 & 20.2 & 12.3 & 17.9 & 19.2 & 8.9 \\
\hline 10060 & 7.3 & 4.6 & 6.1 & 3.2 & 20.7 & 12.2 & 17.8 & 19.2 & 8.9 \\
\hline 10061 & 20.9 & 6.0 & 5.6 & 5.8 & 26.8 & 6.4 & 8.6 & 11.9 & 7.9 \\
\hline 10062 & 19.0 & 6.1 & 3.6 & 9.3 & 26.6 & 6.6 & 8.6 & 12.0 & 8.1 \\
\hline 10063 & 16.0 & 6.9 & 4.6 & 2.7 & 14.0 & 10.9 & 15.8 & 19.6 & 9.6 \\
\hline 10064 & 15.2 & 6.6 & 5.2 & 2.4 & 13.1 & 11.7 & 16.7 & 20.1 & 8.9 \\
\hline 10065 & 2.5 & 1.4 & 1.9 & 0.9 & 5.4 & 5.5 & 12.4 & 22.4 & 47.5 \\
\hline 10066 & 1.9 & 1.7 & 2.6 & 1.3 & 7.0 & 7.1 & 16.0 & 28.5 & 33.8 \\
\hline 10067 & 2.6 & 1.8 & 6.4 & 13.6 & 72.3 & 1.4 & 0.9 & 0.6 & 0.5 \\
\hline 10068 & 2.2 & 2.0 & 5.7 & 10.0 & 77.3 & 1.2 & 0.8 & 0.5 & 0.3 \\
\hline 10069 & 1.3 & 0.3 & 1.2 & 0.3 & 2.5 & 7.4 & 27.9 & 52.5 & 6.6 \\
\hline 10070 & 1.0 & -0.3 & 1.0 & 0.1 & 2.0 & 8.1 & 31.2 & 50.4 & 6.5 \\
\hline 10071 & 1.3 & 0.5 & 0.7 & 0.2 & 0.7 & 1.0 & 5.2 & 26.5 & 63.8 \\
\hline 10072 & 1.0 & 0.7 & 0.8 & 0.2 & 0.6 & 0.8 & 4.6 & 25.6 & 65.7 \\
\hline 10073 & 9.8 & 7.5 & 36.0 & 15.0 & 6.1 & 4.1 & 8.3 & 9.0 & 4.2 \\
\hline 10074 & 9.9 & 7.3 & 38.1 & 12.8 & 6.5 & 4.0 & 8.0 & 9.1 & 4.3 \\
\hline 10075 & 7.7 & 9.1 & 32.5 & 22.0 & 7.3 & 3.9 & 7.3 & 7.5 & 2.7 \\
\hline 10076 & 8.4 & 8.6 & 36.4 & 15.1 & 7.9 & 4.2 & 7.9 & 8.3 & 3.0 \\
\hline 10077 & 5.0 & 2.3 & 26.4 & 18.8 & 10.2 & 7.2 & 12.5 & 13.1 & 4.6 \\
\hline 10078 & 7.7 & 4.6 & 27.8 & 26.6 & 5.7 & 3.5 & 5.5 & 9.8 & 8.8 \\
\hline 10079 & 5.3 & 2.6 & 9.7 & 3.8 & 29.2 & 18.0 & 19.4 & 11.1 & 0.9 \\
\hline 10080 & 5.2 & 2.5 & 11.0 & 4.5 & 28.5 & 17.8 & 18.9 & 10.2 & 0.8 \\
\hline 10081 & 3.3 & 0.3 & 6.7 & 2.4 & 26.8 & 22.1 & 24.1 & 13.3 & 1.0 \\
\hline 10082 & 3.7 & 0.6 & 7.4 & 6.5 & 32.4 & 19.2 & 18.7 & 10.5 & 0.9 \\
\hline 10083 & 6.9 & 1.1 & 5.5 & 1.6 & 44.9 & 33.9 & 5.7 & 0.4 & 0.0 \\
\hline 10084 & 7.1 & 1.3 & 4.9 & 1.8 & 43.6 & 35.1 & 5.7 & 0.4 & 0.0 \\
\hline 10085 & 4.2 & 0.6 & 2.2 & 1.0 & 37.4 & 42.8 & 11.4 & 0.3 & 0.1 \\
\hline 10086 & 5.9 & 1.8 & 3.9 & 1.5 & 43.6 & 36.7 & 5.9 & 0.5 & 0.1 \\
\hline 10087 & 4.3 & 2.4 & 8.7 & 9.4 & 26.6 & 16.8 & 20.5 & 9.9 & 1.4 \\
\hline 10088 & 4.4 & 3.1 & 8.1 & 5.2 & 28.1 & 17.7 & 21.4 & 10.5 & 1.6 \\
\hline 10089 & 3.4 & 0.8 & 7.0 & 6.9 & 33.8 & 17.8 & 19.6 & 9.5 & 1.1 \\
\hline 10090 & 3.2 & 0.8 & 8.0 & 8.1 & 29.5 & 20.4 & 21.4 & 8.1 & 0.8 \\
\hline 10091 & 6.6 & 1.1 & 4.1 & 2.5 & 64.3 & 19.4 & 1.4 & 0.6 & 0.1 \\
\hline 10092 & 6.6 & 1.1 & 4.8 & 2.0 & 64.7 & 18.9 & 1.3 & 0.5 & 0.1 \\
\hline 10093 & 4.7 & 0.7 & 2.7 & 1.8 & 60.2 & 27.8 & 1.8 & 0.3 & 0.0 \\
\hline 10094 & 6.2 & 1.3 & 2.8 & 2.0 & 51.0 & 33.4 & 2.7 & 0.4 & 0.1 \\
\hline 10095 & 57.0 & 13.8 & 4.1 & 1.3 & 2.5 & 2.6 & 6.6 & 8.1 & 4.1 \\
\hline 10096 & 55.1 & 12.9 & 3.7 & 2.1 & 2.9 & 3.0 & 7.3 & 8.8 & 4.2 \\
\hline 10097 & 60.5 & 8.0 & 0.3 & 0.9 & 5.7 & 4.6 & 6.7 & 11.2 & 2.2 \\
\hline 10098 & 65.3 & 7.8 & 0.5 & 1.2 & 3.9 & 2.7 & 4.1 & 8.5 & 6.1 \\
\hline 10099 & 39.1 & 27.2 & 11.4 & 1.3 & 3.2 & 2.6 & 5.4 & 8.6 & 1.1 \\
\hline 10100 & 38.8 & 28.3 & 10.2 & 1.6 & 2.9 & 2.6 & 6.5 & 8.4 & 0.7 \\
\hline 10101 & 2.5 & 2.8 & 6.6 & 7.6 & 21.7 & 19.9 & 21.3 & 12.9 & 4.7 \\
\hline 10102 & 2.5 & 2.8 & 6.6 & 7.6 & 21.7 & 19.9 & 21.3 & 12.9 & 4.7 \\
\hline 10103 & 0.9 & 0.1 & 0.3 & 1.9 & 23.1 & 25.6 & 26.9 & 17 & 4.1 \\
\hline 10104 & 0.9 & 0.1 & 0.3 & 1.9 & 23.1 & 25.6 & 26.9 & 17 & 4.1 \\
\hline 10105 & 0.6 & 0.3 & 0.7 & 2.2 & 20.6 & 22.1 & 29.2 & 21 & 3.4 \\
\hline 10106 & 0.6 & 0.3 & 0.7 & 2.2 & 20.6 & 22.1 & 29.2 & 21 & 3.4 \\
\hline 10107 & 3 & 2.9 & 4 & 2.7 & 22.3 & 21.3 & 23.7 & 14.8 & 5.3 \\
\hline 10108 & 1.2 & 0.4 & 0 & 1.2 & 24.8 & 26.9 & 26.9 & 13.2 & 5.3 \\
\hline 10109 & 1.4 & 0.2 & 0.6 & 1.1 & 23 & 26.8 & 28.7 & 14.4 & 3.7 \\
\hline 10110 & 1.4 & 0.2 & 0.6 & 1.1 & 23 & 26.8 & 28.7 & 14.4 & 3.7 \\
\hline 10111 & 24.4 & 19.9 & 17.1 & 4.7 & 15.2 & 8.4 & 5.3 & 2.7 & 2.4 \\
\hline 10112 & 24.1 & 19.7 & 17.2 & 4.4 & 15.1 & 8.5 & 5.7 & 2.8 & 2.5 \\
\hline 10113 & 27.7 & 21.7 & 14.4 & 4.3 & 14.4 & 8.1 & 5.3 & 2.1 & 2.1 \\
\hline 10114 & 28.4 & 19.2 & 15.2 & 4.2 & 13.4 & 8.4 & 5.9 & 2.9 & 2.4 \\
\hline
\end{tabular}




\begin{tabular}{|c|c|c|c|c|c|c|c|c|c|}
\hline $\begin{array}{l}\text { MIN } \\
\text { a) }\end{array}$ & $<2$ & $2-16$ & $16-50$ & $50-63$ & 63-105 & $105-150$ & $150-210$ & $210-420$ & $420-2000$ \\
\hline 10115 & 22.9 & 12.4 & 25.7 & 10.5 & 25 & 1.7 & 0.6 & 0.9 & 0.3 \\
\hline 10116 & 21.9 & 13.1 & 25.9 & 8 & 27.6 & 1.8 & 0.6 & 0.7 & 0.4 \\
\hline 10117 & 26.2 & 20.8 & 31.5 & 8.6 & 7.7 & 1.9 & 1.7 & 0.9 & 0.5 \\
\hline 10118 & 26.2 & 20.4 & 31.5 & 8.3 & 8.1 & 2.1 & 1.8 & 1 & 0.5 \\
\hline 10119 & 26.3 & 21.9 & 26.9 & 5.6 & 9.5 & 3.9 & 2.9 & 2.4 & 0.6 \\
\hline 10120 & 28.3 & 21.6 & 27.2 & 7.3 & 9.2 & 2.3 & 1.4 & 1.6 & 1 \\
\hline 10121 & 23.9 & 12.6 & 14.6 & 4.6 & 22 & 12.3 & 6.5 & 2.7 & 0.6 \\
\hline 10122 & 23.5 & 12.7 & 14.7 & 5.3 & 21.8 & 12.2 & 6.2 & 2.8 & 0.8 \\
\hline 10123 & 56.8 & 32.1 & 8.5 & $1.2^{\mathrm{b})}$ & - & 0.1 & 0 & 0.6 & 0.7 \\
\hline 10124 & 58.5 & 33.6 & 5.9 & $0.8^{b)}$ & - & 0.2 & 0.1 & 0.5 & 0.3 \\
\hline 10125 & 58.5 & 33.6 & 5.9 & $0.8^{b)}$ & - & 0.2 & 0.1 & 0.5 & 0.3 \\
\hline 10126 & 58.5 & 33.6 & 5.9 & $0.8^{b)}$ & - & 0.2 & 0.1 & 0.5 & 0.3 \\
\hline 10127 & 46.7 & 31.5 & 17 & $2.8^{b)}$ & - & 0.3 & 0.9 & 0.6 & 0.2 \\
\hline 10128 & 46.7 & 31.5 & 17 & $2.8^{b)}$ & - & 0.3 & 0.9 & 0.6 & 0.2 \\
\hline 10129 & 56.8 & 32.1 & 8.5 & $1.2^{b)}$ & - & 0.1 & 0 & 0.6 & 0.7 \\
\hline 10130 & 58.5 & 33.6 & 5.9 & $0.8^{b)}$ & - & 0.2 & 0.1 & 0.5 & 0.3 \\
\hline 10131 & 58.5 & 33.6 & 5.9 & $0.8^{b)}$ & - & 0.2 & 0.1 & 0.5 & 0.3 \\
\hline 10132 & 58.5 & 33.6 & 5.9 & $0.8^{b)}$ & - & 0.2 & 0.1 & 0.5 & 0.3 \\
\hline
\end{tabular}

a) MIN = Monster Identificatie Nummer.

b) De textuurklasse is voor dit monster afwijkend: 50-105 $\mu \mathrm{m}$. 


\subsection{Dichtheid en gloeiverlies}

In Tabel 9 is van de nieuwe monsters de droge bulkdichtheid en het gloeiverlies weergegeven.

Tabel 9 Droge bulkdichtheid en gloeiverlies.

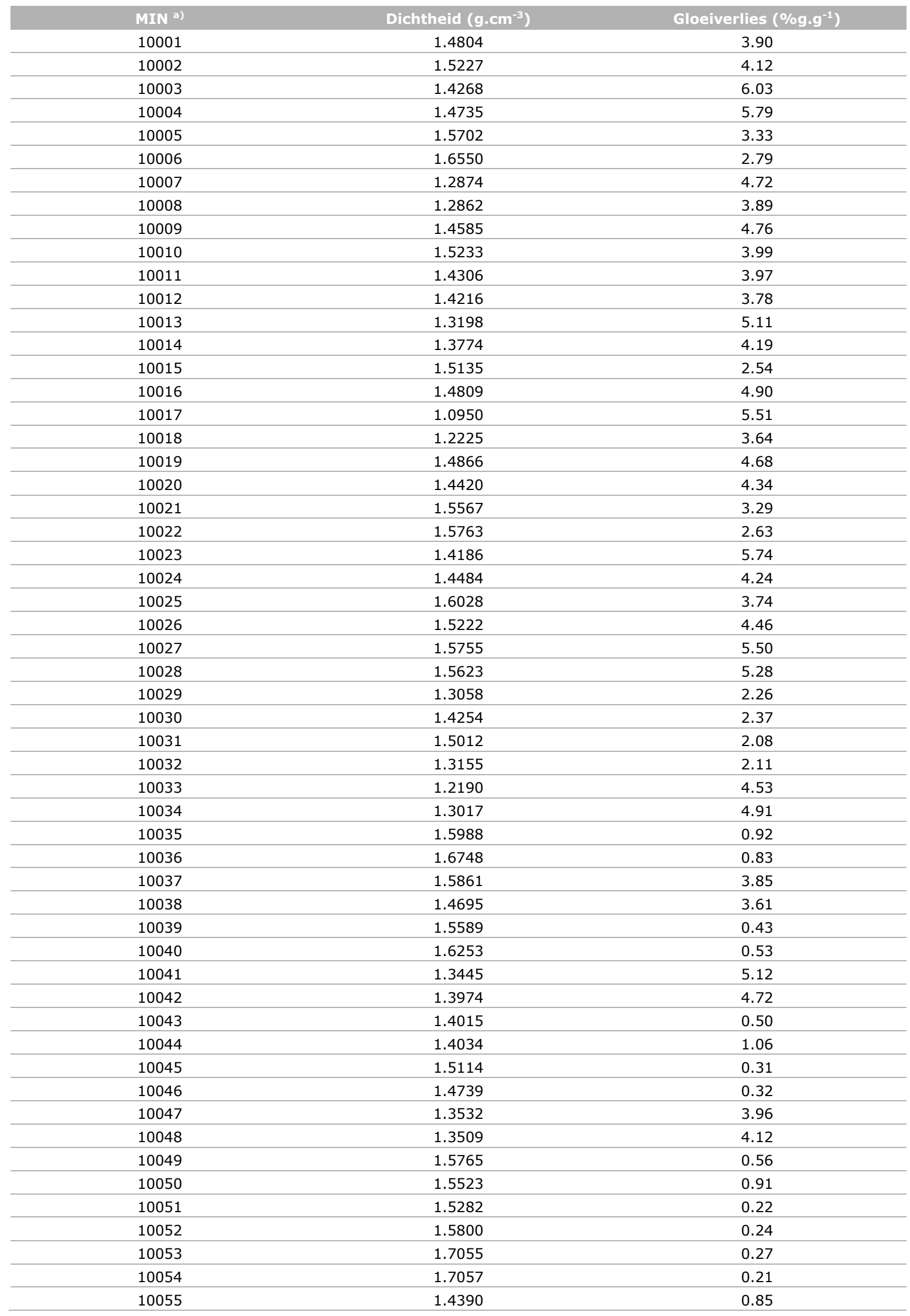




\begin{tabular}{|c|c|c|}
\hline MIN a) & Dichtheid $\left(\mathrm{g} \cdot \mathrm{cm}^{-3}\right)$ & Gloeiverlies $\left(\% \mathrm{~g} \cdot \mathrm{g}^{-1}\right)$ \\
\hline 10056 & 1.4820 & 1.19 \\
\hline 10057 & 1.4525 & 0.81 \\
\hline 10058 & 1.4416 & 0.73 \\
\hline 10059 & 1.6186 & 3.67 \\
\hline 10060 & 1.5209 & 3.78 \\
\hline 10061 & 1.5088 & 2.13 \\
\hline 10062 & 1.5483 & 2.26 \\
\hline 10063 & 1.7884 & 1.22 \\
\hline 10064 & 1.6856 & 1.36 \\
\hline 10065 & 1.6808 & 0.95 \\
\hline 10066 & 1.6390 & 0.84 \\
\hline 10067 & 1.3861 & 1.90 \\
\hline 10068 & 1.3960 & 2.35 \\
\hline 10069 & 1.5851 & 0.49 \\
\hline 10070 & 1.5286 & 0.57 \\
\hline 10071 & 1.5149 & 0.43 \\
\hline 10072 & 1.5402 & 0.42 \\
\hline 10073 & 1.5631 & 2.54 \\
\hline 10074 & 1.5844 & 2.81 \\
\hline 10075 & 1.2966 & 1.77 \\
\hline 10076 & 1.5487 & 1.88 \\
\hline 10077 & 1.5058 & 1.50 \\
\hline 10078 & 1.5970 & 1.83 \\
\hline 10079 & 1.4214 & 3.14 \\
\hline 10080 & 1.4116 & 3.33 \\
\hline 10081 & 1.4891 & 1.69 \\
\hline 10082 & 1.5139 & 1.19 \\
\hline 10083 & 1.5768 & 1.98 \\
\hline 10084 & 1.6454 & 2.14 \\
\hline 10085 & 1.5719 & 1.50 \\
\hline 10086 & 1.6808 & 1.62 \\
\hline 10087 & 1.3337 & 8.10 \\
\hline 10088 & 1.3364 & 7.95 \\
\hline 10089 & 1.4484 & 2.73 \\
\hline 10090 & 1.5132 & 3.67 \\
\hline 10091 & 1.5753 & 3.38 \\
\hline 10092 & 1.5502 & 2.05 \\
\hline 10093 & 1.6038 & 1.04 \\
\hline 10094 & 1.5585 & 2.25 \\
\hline 10095 & 0.6498 & 28.45 \\
\hline 10096 & 0.6447 & 28.46 \\
\hline 10097 & 0.6407 & 43.72 \\
\hline 10098 & 0.5189 & 36.12 \\
\hline 10099 & 0.8615 & 29.58 \\
\hline 10100 & 0.8752 & 28.23 \\
\hline 10101 & 1.355 & 4.34 \\
\hline 10102 & 1.475 & - \\
\hline 10103 & 1.711 & 0.95 \\
\hline 10104 & 1.662 & - \\
\hline 10105 & 1.754 & 0.67 \\
\hline 10106 & 1.778 & - \\
\hline 10107 & 1.399 & 4.58 \\
\hline 10108 & 1.705 & 1.22 \\
\hline 10109 & 1.726 & 1.07 \\
\hline 10110 & - & - \\
\hline 10111 & 1.530 & 4.52 \\
\hline 10112 & 1.457 & 4.56 \\
\hline 10113 & 1.597 & 3.55 \\
\hline 10114 & 1.585 & 3.54 \\
\hline 10115 & 1.521 & 3.89 \\
\hline 10116 & 1.493 & 3.68 \\
\hline 10117 & 1.538 & 5.44 \\
\hline 10118 & 1.546 & 5.19 \\
\hline 10119 & 1.459 & 4.12 \\
\hline
\end{tabular}




\begin{tabular}{|c|c|c|}
\hline MIN a) & Dichtheid $\left(\mathrm{g} . \mathrm{cm}^{-3}\right)$ & Gloeiverlies $\left(\% \mathrm{~g} \cdot \mathrm{g}^{-1}\right)$ \\
\hline 10120 & 1.353 & 3.80 \\
\hline 10122 & 1.496 & 4.08 \\
\hline 10123 & 1.1340 & 10.88 \\
\hline 10126 & 1.1820 & 8.51 \\
\hline 10127 & 0.9260 & 12.94 \\
\hline 10128 & 0.7770 & 13.92 \\
\hline 10129 & 1.1660 & 9.80 \\
\hline
\end{tabular}

a) MIN = Monster Identificatie Nummer.
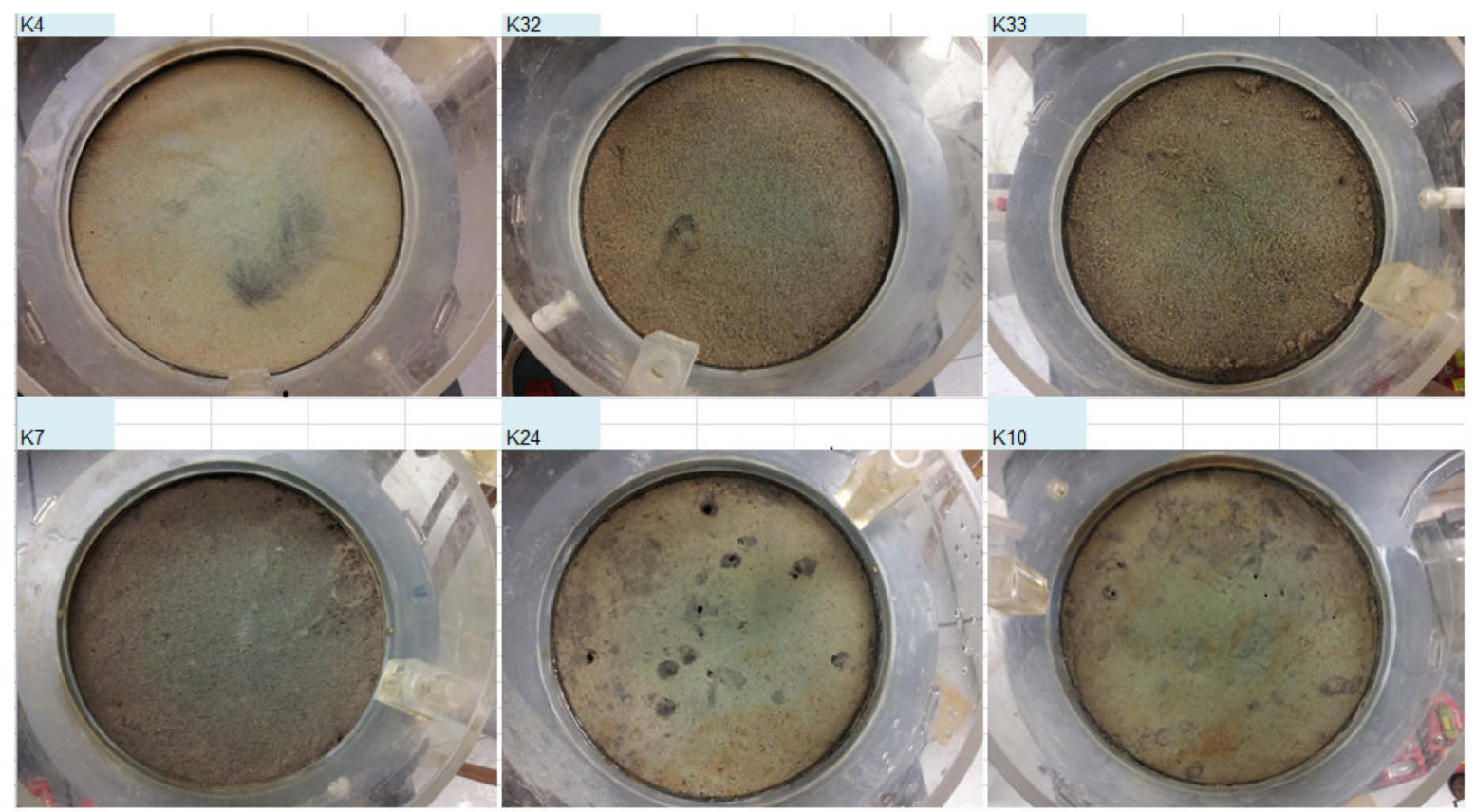

Figuur 3.1 Enkele monsters van de meetopstelling voor de verzadigde waterdoorlatendheid. 


\subsection{Mualem-Van Genuchten-parameters van de prefit}

In veel gevallen bleek het gewenst om een 2- of 3-modale Van Genuchten-curve te hanteren in de prefit. Omdat de prefit alleen is gebruikt om watergehaltes te schatten bij de gemeten drukhoogten en vervolgens in de tweede stap de uiteindelijke Mualem-van Genuchten-optimalisatie is uitgevoerd, worden de tussenresultaten hier niet vermeld. De prefit is per bodemmonster opgeslagen in de afzonderlijke Excelbestanden.

\subsection{Mualem-Van Genuchten-parameters van de eindfit}

In Tabel 10 zijn de Mualem-Van Genuchten-parameters gegeven van de eindfit. De verzadigde waterdoorlatendheid van de fit $\left(K_{s}^{s}\right)$ is doorgaans (veel) kleiner dan de gemeten doorlatendheid bij verzadiging $\left(K_{s}^{m}\right)$ als gevolg van de invloed van de macroporiën die in de fit niet, maar in de directe meting wel een grote rol spelen.

Tabel 10 De Mualem-Van Genuchten-parameters die zijn vastgesteld op basis van alle beschikbare meetgegevens van drukhoogten en vochtgehalten. In de rechterkolom is tevens de gemeten verzadigde waterdoorlatendheid $\left(K_{s}^{m}\right)$ gegeven. Verder is uitgegaan van $m=1-1 / n$.

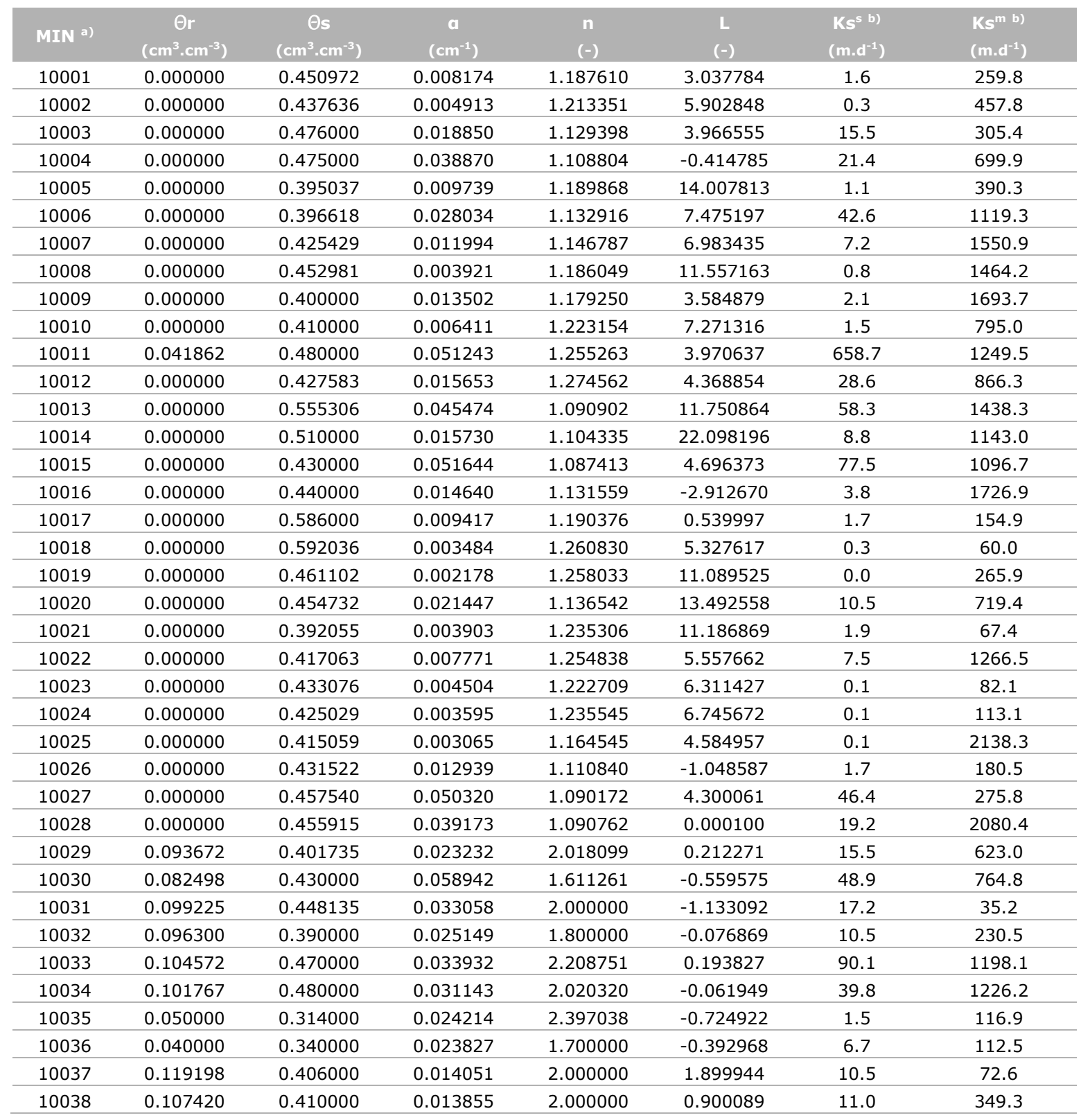




\begin{tabular}{|c|c|c|c|c|c|c|c|}
\hline MIN a) & $\begin{array}{c}\text { Or } \\
\left(\mathrm{cm}^{3} \cdot \mathrm{cm}^{-3}\right)\end{array}$ & $\begin{array}{c}\text { Os } \\
\left(\mathrm{cm}^{3} \cdot \mathrm{cm}^{-3}\right)\end{array}$ & $\begin{array}{c}\text { a } \\
\left(\mathrm{cm}^{-1}\right)\end{array}$ & $\begin{array}{c}n \\
(-)\end{array}$ & $\begin{array}{l}L \\
(-)\end{array}$ & $\begin{array}{l}\left.K s^{s} \mathrm{~b}\right) \\
\left(\mathrm{m} \cdot \mathrm{d}^{-1}\right)\end{array}$ & $\begin{array}{l}\left.K s^{\mathrm{m} \mathrm{b}}\right) \\
\left(\mathrm{m} \cdot \mathrm{d}^{-1}\right)\end{array}$ \\
\hline 10039 & 0.036623 & 0.322113 & 0.030908 & 3.000000 & -0.997628 & 3.5 & 145.2 \\
\hline 10040 & 0.071432 & 0.305919 & 0.025292 & 3.000000 & -0.275297 & 24.4 & 83.7 \\
\hline 10041 & 0.132366 & 0.480000 & 0.011273 & 1.612448 & 5.552503 & 22.9 & 84.7 \\
\hline 10042 & 0.080354 & 0.490000 & 0.008823 & 1.475626 & 7.144081 & 11.8 & 540.1 \\
\hline 10043 & 0.035469 & 0.420000 & 0.009157 & 5.705278 & 0.232504 & 4.2 & 58.5 \\
\hline 10044 & 0.070634 & 0.460000 & 0.009242 & 5.805063 & -0.146651 & 9.4 & 14.7 \\
\hline 10045 & 0.000000 & 0.379815 & 0.027596 & 5.607569 & -0.974542 & 2.8 & 1253.2 \\
\hline 10046 & 0.043010 & 0.380000 & 0.031225 & 5.500000 & -0.721732 & 13.1 & 1161.9 \\
\hline 10047 & 0.080532 & 0.465045 & 0.015508 & 1.474650 & 6.387758 & 55.5 & 73.2 \\
\hline 10048 & 0.102886 & 0.459852 & 0.012999 & 1.715768 & 4.174926 & 32.9 & 191.1 \\
\hline 10049 & 0.043896 & 0.310000 & 0.015049 & 3.251305 & -0.041415 & 3.6 & 288.7 \\
\hline 10050 & 0.041553 & 0.340000 & 0.014402 & 2.682156 & 1.079650 & 3.9 & 40.2 \\
\hline 10051 & 0.050900 & 0.361058 & 0.031147 & 5.777075 & -0.749332 & 55.2 & 1238.0 \\
\hline 10052 & 0.028835 & 0.345062 & 0.028783 & 5.065705 & -0.766187 & 13.4 & 1239.6 \\
\hline 10053 & 0.020577 & 0.286682 & 0.034872 & 4.064356 & -0.856990 & 2.0 & 463.7 \\
\hline 10054 & 0.032030 & 0.310000 & 0.019391 & 5.024249 & -0.804548 & 4.0 & 670.9 \\
\hline 10055 & 0.040063 & 0.345684 & 0.022761 & 2.008150 & -0.016092 & 8.5 & 241.0 \\
\hline 10056 & 0.047393 & 0.378171 & 0.026100 & 2.556275 & 0.198126 & 21.5 & 665.0 \\
\hline 10057 & 0.030565 & 0.395000 & 0.021618 & 4.190625 & 0.360432 & 26.8 & 346.7 \\
\hline 10058 & 0.033983 & 0.385000 & 0.022221 & 4.747635 & -0.280765 & 31.4 & 177.4 \\
\hline 10059 & 0.000000 & 0.395808 & 0.009614 & 1.286788 & 6.331613 & 10.7 & 378.3 \\
\hline 10060 & 0.000000 & 0.408446 & 0.010762 & 1.294969 & 3.661327 & 12.9 & 174.5 \\
\hline 10061 & 0.000000 & 0.417939 & 0.003448 & 1.142355 & 3.855992 & 0.2 & 7.4 \\
\hline 10062 & 0.000000 & 0.427827 & 0.003373 & 1.148864 & 7.868708 & 0.2 & 84.0 \\
\hline 10063 & 0.000000 & 0.281122 & 0.020113 & 1.187284 & -0.832973 & 4.9 & 6.6 \\
\hline 10064 & 0.010636 & 0.300000 & 0.023570 & 1.217745 & 5.205625 & 34.7 & 18.4 \\
\hline 10065 & 0.041794 & 0.284654 & 0.040404 & 1.662751 & 0.250227 & 266.8 & 145.8 \\
\hline 10066 & 0.048044 & 0.300000 & 0.039906 & 1.847285 & -0.326950 & 105.6 & 340.9 \\
\hline 10067 & 0.049876 & 0.483641 & 0.006815 & 3.823948 & 0.830086 & 8.2 & 88.1 \\
\hline 10068 & 0.057229 & 0.480000 & 0.008265 & 3.064624 & 1.136109 & 30.2 & 107.3 \\
\hline 10069 & 0.037345 & 0.350000 & 0.026255 & 5.576863 & -0.849298 & 13.8 & 533.7 \\
\hline 10070 & 0.034034 & 0.340000 & 0.025407 & 4.818143 & -0.599885 & 22.6 & 1137.8 \\
\hline 10071 & 0.025933 & 0.340463 & 0.052121 & 3.050017 & -1.142803 & 8.9 & 2681.9 \\
\hline 10072 & 0.038447 & 0.338320 & 0.046111 & 4.615859 & -0.999048 & 35.1 & 2664.4 \\
\hline 10073 & 0.038666 & 0.389631 & 0.007895 & 1.419464 & 0.595961 & 2.5 & 1366.0 \\
\hline 10074 & 0.056397 & 0.373680 & 0.003617 & 1.610946 & 2.352115 & 1.0 & 1304.1 \\
\hline 10075 & 0.035062 & 0.405453 & 0.007492 & 1.500907 & 2.176377 & 9.9 & 441.2 \\
\hline 10076 & 0.091988 & 0.487044 & 0.008479 & 1.863352 & 0.551994 & 16.7 & 7.4 \\
\hline 10077 & 0.064792 & 0.390000 & 0.007211 & 1.735346 & 3.468448 & 34.3 & 22.5 \\
\hline 10078 & 0.081224 & 0.361228 & 0.006684 & 2.338892 & 1.912414 & 45.9 & 12.7 \\
\hline 10079 & 0.068642 & 0.412000 & 0.008324 & 1.779788 & 2.236931 & 10.4 & 1071.1 \\
\hline 10080 & 0.062638 & 0.431000 & 0.014781 & 1.557488 & 1.394848 & 41.6 & 26.6 \\
\hline 10081 & 0.063010 & 0.410000 & 0.013028 & 1.709011 & 0.919393 & 61.3 & 54.2 \\
\hline 10082 & 0.065112 & 0.389417 & 0.008098 & 1.889165 & 1.357510 & 17.0 & 101.4 \\
\hline 10083 & 0.086160 & 0.360000 & 0.010321 & 1.724363 & 2.361924 & 1.7 & 3.6 \\
\hline 10084 & 0.096441 & 0.360000 & 0.009195 & 1.766291 & 3.573490 & 2.3 & 7.5 \\
\hline 10085 & 0.078679 & 0.348531 & 0.012891 & 1.723542 & -0.270576 & 1.2 & 1.5 \\
\hline 10086 & 0.078216 & 0.346277 & 0.013847 & 1.628116 & -1.001202 & 1.0 & 1.1 \\
\hline 10087 & 0.000000 & 0.487427 & 0.007714 & 1.237043 & 8.843949 & 11.9 & 939.7 \\
\hline 10088 & 0.000000 & 0.480000 & 0.006166 & 1.237493 & 2.669459 & 3.5 & 14.5 \\
\hline 10089 & 0.000000 & 0.460000 & 0.006339 & 1.311151 & 1.744644 & 9.5 & 44.5 \\
\hline 10090 & 0.000000 & 0.435000 & 0.003989 & 1.465165 & 2.850440 & 3.0 & 13.3 \\
\hline 10091 & 0.095008 & 0.371000 & 0.009113 & 2.450403 & 0.939675 & 1.7 & 79.7 \\
\hline 10092 & 0.090854 & 0.370000 & 0.009520 & 2.232756 & 1.457228 & 3.5 & 81.8 \\
\hline 10093 & 0.106499 & 0.388151 & 0.009223 & 2.040044 & 4.259281 & 6.4 & 16.7 \\
\hline 10094 & 0.113365 & 0.378000 & 0.009697 & 2.999150 & 1.108878 & 5.7 & 78.4 \\
\hline 10095 & 0.000000 & 0.710000 & 0.020017 & 1.137665 & 6.329056 & 6.4 & 823.5 \\
\hline 10096 & 0.000000 & 0.710000 & 0.028113 & 1.117878 & 18.586666 & 156.7 & 681.0 \\
\hline 10097 & 0.000000 & 0.790000 & 0.014338 & 1.107252 & 24.285676 & 63.8 & 204.5 \\
\hline 10098 & 0.000000 & 0.780000 & 0.025997 & 1.087423 & 13.241214 & 42.8 & 12.9 \\
\hline 10099 & 0.000000 & 0.658400 & 0.012944 & 1.112651 & 8.298246 & 19.2 & 54.7 \\
\hline 10100 & 0.000000 & 0.629800 & 0.020838 & 1.100764 & 16.876455 & 192.1 & 107.0 \\
\hline 10101 & 0.14863 & 0.46094 & 0.01254 & 2.14897 & 0.79480 & 9.49822 & 21.9 \\
\hline
\end{tabular}




\begin{tabular}{|c|c|c|c|c|c|c|c|}
\hline MIN a) & $\begin{array}{c}\text { Or } \\
\left(\mathrm{cm}^{3} \cdot \mathrm{cm}^{-3}\right)\end{array}$ & $\begin{array}{c}\text { Os } \\
\left(\mathrm{cm}^{3} \cdot \mathrm{cm}^{-3}\right)\end{array}$ & $\begin{array}{c}a \\
\left(\mathrm{~cm}^{-1}\right)\end{array}$ & $\begin{array}{c}n \\
(-)\end{array}$ & $\begin{array}{l}L \\
(-)\end{array}$ & $\begin{array}{l}K s^{s b)} \\
\left(m \cdot d^{-1}\right)\end{array}$ & $\begin{array}{l}\left.K s^{\mathrm{m} \mathrm{b}}\right) \\
\left(\mathrm{m} \cdot \mathrm{d}^{-1}\right)\end{array}$ \\
\hline 10102 & - & - & - & - & - & - & - \\
\hline 10103 & 0.04235 & 0.31038 & 0.01425 & 2.56280 & 0.53422 & 20.16607 & 54.4 \\
\hline 10104 & - & - & - & - & - & - & 36.9 \\
\hline 10105 & 0.02281 & 0.28564 & 0.01034 & 2.88488 & 1.60622 & 11.22423 & 45.1 \\
\hline 10106 & - & - & - & - & - & - & - \\
\hline 10107 & 0.03072 & 0.44793 & 0.02151 & 1.22610 & 4.73126 & 58.62911 & 106 \\
\hline 10108 & 0.06593 & 0.32378 & 0.00778 & 3.33731 & 0.44457 & 6.92437 & 24.9 \\
\hline 10109 & 0.04140 & 0.32597 & 0.01286 & 3.89207 & -0.20809 & 7.80344 & 416.2 \\
\hline 10110 & - & - & - & - & - & - & 167.4 \\
\hline 10111 & 0.00000 & 0.42978 & 0.02015 & 1.08240 & -17.99725 & 0.87901 & 22.4 \\
\hline 10112 & 0.00000 & 0.45068 & 0.01953 & 1.08041 & 0.00010 & 13.37103 & 8.1 \\
\hline 10113 & 0.19501 & 0.40182 & 0.01674 & 1.19521 & -2.86683 & 0.32215 & 17.3 \\
\hline 10114 & 0.24372 & 0.39496 & 0.01534 & 1.57964 & -2.00000 & 0.08603 & 86.1 \\
\hline 10115 & 0.00000 & 0.42588 & 0.01867 & 1.08281 & -12.87140 & 2.27714 & 177.2 \\
\hline 10116 & 0.00000 & 0.42824 & 0.03007 & 1.08650 & 0.00010 & 13.99210 & 201.6 \\
\hline 10117 & 0.00000 & 0.47884 & 0.06093 & 1.08819 & 0.00010 & 182.62373 & 437.2 \\
\hline 10118 & 0.00000 & 0.44063 & 0.02144 & 1.07769 & 0.00010 & 16.25975 & 1231.8 \\
\hline 10119 & 0.00000 & 0.49919 & 0.07094 & 1.07389 & 0.00010 & 185.65149 & 654 \\
\hline 10120 & P.M. & P.M. & P.M. & P.M. & P.M. & P.M. & 272 \\
\hline 10121 & 0.00000 & 0.46068 & 0.13179 & 1.05774 & -13.77067 & 55.97265 & 1314 \\
\hline 10122 & 0.25430 & 0.47738 & 0.04855 & 1.27124 & -3.80759 & 1.18572 & 1733 \\
\hline 10123 & 0.24784 & 0.55460 & 0.00464 & 1.30321 & 0.73245 & 0.05198 & 590.2 \\
\hline 10124 & 0.00000 & 0.50257 & 0.01740 & 1.06394 & -9.81823 & 1.31178 & 0.2 \\
\hline 10125 & 0.00000 & 0.57692 & 0.01368 & 1.07267 & -10.00000 & 0.88714 & 0.5 \\
\hline 10126 & 0.00000 & 0.56568 & 0.01722 & 1.05880 & 0.00010 & 3.01912 & 2.3 \\
\hline 10127 & 0.00000 & 0.63774 & 0.00281 & 1.14292 & -1.99990 & 0.96164 & 391.3 \\
\hline 10128 & 0.00000 & 0.70341 & 0.00567 & 1.13463 & 0.00010 & 2.00000 & 202.9 \\
\hline 10129 & 0.24856 & 0.55622 & 0.00377 & 1.25964 & -2.98076 & 0.02451 & 356.1 \\
\hline 10130 & 0.00000 & 0.50643 & 0.00734 & 1.08870 & 0.00010 & 0.43300 & 6.3 \\
\hline 10131 & 0.00000 & 0.51613 & 0.01223 & 1.07068 & 0.00000 & 1.43769 & 0.01 \\
\hline 10132 & 0.10483 & 0.55691 & 0.00664 & 1.08497 & -20.00000 & 0.10774 & 2.2 \\
\hline
\end{tabular}

a) MIN = Monster Identificatie Nummer.

b) Tijdens de meting van de verzadigde waterdoorlatendheid hebben macroporiën, zoals wormgaten en wortelkanalen, grote invloed op de resultaten. Met de verdampingsmethode worden doorlatendheden afgeleid in het drukhoogtegebied $h<-50 \mathrm{~cm}$, waardoor de invloed van de macroporiën onvoldoende wordt meegenomen. Het effect van macroporiën komt daarom ook onvoldoende tot uitdrukking in de Mualem-Van Genuchten-fit. De werkelijk gemeten verzadigde doorlatendheid $K s^{m}$ kan daarom veel groter zijn dan de modelparameter $K s^{s}$. 


\subsection{Koppeling extra monsters Priapus met metadata}

Behalve de in de periode 2012-2014 verworven nieuwe data, zijn er in Priapus al bodemfysische data van hoge kwaliteit aanwezig. Van de meeste monsters zijn metagegevens, zoals profielbeschrijvingen en grondwaterstanden, terug te vinden in de BIS-database. Van andere monsters is dat niet het geval, maar is er literatuur gevonden die relevante metadata bevatten.

In de Tabellen 9A en 9B is een overzicht gegeven van bestaande monsters in Priapus, waarvan:

- in Priapus geen, maar in BIS wel metagegevens aanwezig zijn (44 stuks). In dit project is daarmee een directe koppeling gemaakt. De gegevens moeten nog een aanpassing in de datastructuur en klasse-indelingen ondergaan, zodat zij op uniforme wijze in BIS ondergebracht kunnen worden. De afgeleide gegevens zijn al fysiek in BIS ondergebracht (Tabel 9A).

- in Priapus en BIS geen profielbeschrijvingen en metagegevens aanwezig zijn, maar waarvan wel literatuur is gevonden met metagegevens ( 53 stuks). In de tabel is de koppeling gelegd tussen de monsters in Priapus en de betreffende literatuur, zodat het overbrengen van de gecombineerde data naar BIS makkelijker kan worden uitgevoerd. Deze gegevens zijn nog niet in BIS ondergebracht.

Tabel 9A Bestaande Priapus-monsters, met koppeling aan bestaande metadata uit BIS, waarvan alleen de afgeleide gegevens in BIS zijn opgenomen. Overige gegevens worden in een later stadium toegevoegd.

\begin{tabular}{|c|c|c|c|c|c|}
\hline Afzettings-milieu & Textuurklasse & $\begin{array}{l}\text { Boven- of } \\
\text { Onder- } \\
\text { Grond (B/O) }\end{array}$ & MIN a) & $\begin{array}{l}\text { X-coör- } \\
\text { dinaat }\end{array}$ & $\begin{array}{l}\text { Y-coör- } \\
\text { dinaat }\end{array}$ \\
\hline \multirow{9}{*}{$\begin{array}{l}\text { Moerig } \\
-100\end{array}$} & Bosveen & 0 & 1686,1690 & 117250 & 461400 \\
\hline & \multirow{2}{*}{ Kleiig veen } & \multirow{2}{*}{$\mathrm{B}$} & 1684,1685 & 117250 & 461400 \\
\hline & & & 1692,1693 & 117600 & 461125 \\
\hline & \multirow{2}{*}{$\begin{array}{c}\text { Mesotroof en eutroof } \\
\text { veen }\end{array}$} & \multirow{2}{*}{$\mathrm{O}$} & 1645,1646 & 120075 & 447200 \\
\hline & & & 1650 & 119600 & 446850 \\
\hline & \multirow{2}{*}{ Riet-zegge-veen } & \multirow{2}{*}{$\mathrm{O}$} & 1687 & 117250 & 461400 \\
\hline & & & 1695 & 117600 & 461125 \\
\hline & Venig zand & B & 1830 & 253000 & 460000 \\
\hline & Zeer fijn zand & B & 1614 & 251200 & 569025 \\
\hline \multirow{8}{*}{$\begin{array}{l}\text { Mariene afzettingen } \\
\qquad-200\end{array}$} & Lichte klei & B & 1663,1664 & 49300 & 398000 \\
\hline & \multirow{3}{*}{ Matig lichte zavel } & B & 1651,1653 & 43650 & 398875 \\
\hline & & \multirow{2}{*}{$\mathrm{O}$} & 1622 & 46350 & 401075 \\
\hline & & & 1654 & 43650 & 398875 \\
\hline & Matig zware klei & $\mathrm{O}$ & 1665,1666 & 49300 & 398000 \\
\hline & Uiterst fijn zand & $\mathrm{O}$ & 1624 & 46350 & 401075 \\
\hline & Zeer lichte zavel & $\mathrm{O}$ & 1655,1656 & 43650 & 398875 \\
\hline & Zware zavel & B & 1621 & 46350 & 401075 \\
\hline \multirow{4}{*}{$\begin{array}{l}\text { Fluviatiele afzettingen } \\
\qquad-300\end{array}$} & Matig zware klei & B & 1611 & 170875 & 445200 \\
\hline & $\begin{array}{l}\text { Zeer fijn tot matig } \\
\text { fijn zand }\end{array}$ & B & 60 & 260000 & 491000 \\
\hline & \multirow{2}{*}{ Zeer zware klei } & $\mathrm{B}$ & 1643 & 120075 & 447200 \\
\hline & & $\mathrm{O}$ & 1644 & 120075 & 447200 \\
\hline \multirow{3}{*}{$\begin{array}{l}\text { Eolische en fluvio- } \\
\text { periglaciale afzettingen } \\
-400\end{array}$} & Matig fijn zand & $\mathrm{O}$ & 1612,1613 & 170875 & 445200 \\
\hline & \multirow[b]{2}{*}{ Zeer fijn zand } & B & $\begin{array}{c}1675,1678 \\
1679\end{array}$ & 239975 & 553900 \\
\hline & & $\mathrm{O}$ & $\begin{array}{c}1676,1677 \\
1680,1681 \\
1682\end{array}$ & 239975 & 553900 \\
\hline \multirow{2}{*}{$\begin{array}{l}\text { Glaciale en fluvio- } \\
\text { glaciale afzettingen } \\
-500\end{array}$} & \multirow[b]{2}{*}{ Keileem } & \multirow[b]{2}{*}{$\mathrm{B}$} & 50 & 263000 & 480000 \\
\hline & & & 67 & 245000 & 563000 \\
\hline $\begin{array}{l}\text { Overige afzettingen } \\
\qquad-600\end{array}$ & Matig fijn zand & B & $\begin{array}{c}1631,1632 \\
1633\end{array}$ & 167575 & 452700 \\
\hline
\end{tabular}

a) MIN = Monster Identificatie Nummer. 
Tabel 9B Bestaande Priapus-monsters, met softe koppeling aan metadata uit literatuur. Deze gegevens zijn nog niet in BIS opgenomen.

\begin{tabular}{|c|c|c|c|c|c|c|}
\hline $\begin{array}{l}\text { Afzettings- } \\
\text { milieu }\end{array}$ & Textuurklasse & $\begin{array}{c}\text { Boven- of } \\
\text { Onder- } \\
\text { Grond }(B / O)\end{array}$ & MIN a) & $\begin{array}{l}\text { X-coör- } \\
\text { dinaat }\end{array}$ & $\begin{array}{l}\text { Y-coör- } \\
\text { dinaat }\end{array}$ & Literatuur \\
\hline \multirow{7}{*}{$\begin{array}{l}\text { Moerig } \\
-100\end{array}$} & Venig zand & B & 75 & 221000 & 522000 & Dodewaard, 1997 \\
\hline & \multirow{2}{*}{$\begin{array}{c}\text { Zandige } \\
\text { veen en } \\
\text { veen }\end{array}$} & B & 35,36 & 223504 & 459500 & Kleijer, 2000 \\
\hline & & $\mathrm{O}$ & 1859 & 227000 & 556000 & Hamming, 1961 \\
\hline & \multirow{4}{*}{ Onbekend } & $\mathrm{B}$ & 1956 & 120430 & 446510 & Bles et al. 1969 \\
\hline & & & 1943,1944 & 117350 & 461150 & Beuving et al. 1996 \\
\hline & & $\mathrm{O}$ & $\begin{array}{c}1945,1946 \\
1947\end{array}$ & 117250 & 461400 & Beuving et al. 1996 \\
\hline & & & 1957 & 120430 & 446510 & Bles et al. 1969 \\
\hline \multirow{8}{*}{$\begin{array}{c}\text { Mariene } \\
\text { afzettingen } \\
-200\end{array}$} & $\begin{array}{c}\text { Matig lichte } \\
\text { zavel }\end{array}$ & $\mathrm{O}$ & 1662 & 223225 & 602075 & Kamping et al. 1968 \\
\hline & \multirow{2}{*}{$\begin{array}{l}\text { Matig zware } \\
\text { klei }\end{array}$} & $\mathrm{B}$ & 1667,1668 & 273300 & 579650 & Klungel, 1970 \\
\hline & & $\mathrm{O}$ & 1670 & 273300 & 579650 & Klungel, 1970 \\
\hline & \multirow{2}{*}{$\begin{array}{l}\text { Zeer lichte } \\
\text { zavel }\end{array}$} & B & 1657,1658 & 223225 & 602075 & Kamping et al. 1968 \\
\hline & & $\mathrm{O}$ & $\begin{array}{c}1659,1660 \\
1661\end{array}$ & 223225 & 602075 & Kamping et al. 1968 \\
\hline & \multirow{3}{*}{$\begin{array}{c}\text { Zeer zware } \\
\text { klei }\end{array}$} & $\mathrm{B}$ & 1672 & 174300 & 583450 & Cnossen et al. 1965 \\
\hline & & \multirow{2}{*}{$\mathrm{O}$} & 1669,1671 & 273300 & 579650 & Klungel, 1970 \\
\hline & & & 1673,1674 & 174300 & 583450 & Cnossen et al. 1965 \\
\hline \multirow{2}{*}{$\begin{array}{c}\text { Mariene } \\
\text { afzettingen } \\
-200\end{array}$} & \multirow[b]{2}{*}{ Onbekend } & \multirow[b]{2}{*}{ B } & 1941,1942 & 103408 & 407700 & Te Riele et al. 1968 \\
\hline & & & $\begin{array}{c}1949,1950 \\
1951\end{array}$ & 179833 & 577213 & Hoving et al. 2006 \\
\hline \multirow{10}{*}{$\begin{array}{l}\text { Fluviatiele } \\
\text { afzettingen } \\
-300\end{array}$} & $\begin{array}{l}\text { Matig lichte } \\
\text { zavel }\end{array}$ & B & 29,30 & 224620 & 460325 & Kleijer, 2000 \\
\hline & \multirow{2}{*}{$\begin{array}{l}\text { Matig zware } \\
\text { klei }\end{array}$} & $\mathrm{B}$ & 1126 & 144829 & 428998 & Van der Sluys, 1956 \\
\hline & & 0 & 1138,1140 & 144829 & 428998 & Van der Sluys, 1956 \\
\hline & \multirow{2}{*}{$\begin{array}{l}\text { Zeer fijn tot } \\
\text { matig fijn } \\
\text { zand }\end{array}$} & $\mathrm{B}$ & $23,24,25$ & 223965 & 460246 & Kleijer, 2000 \\
\hline & & $\mathrm{O}$ & 37 & 223504 & 459500 & Kleijer, 2000 \\
\hline & $\begin{array}{l}\text { Zeer fijn? } \\
\text { zand }\end{array}$ & $\mathrm{O}$ & 11 & 158000 & 397000 & Bles et al. 1975,1976 \\
\hline & $\begin{array}{l}\text { Zeer grof? } \\
\text { zand }\end{array}$ & $\mathrm{O}$ & 10 & 158000 & 397000 & Bles et al. 1975,1976 \\
\hline & \multirow{2}{*}{$\begin{array}{c}\text { Zeer zware } \\
\text { klei }\end{array}$} & \multirow{2}{*}{ B } & 513 & 123000 & 443000 & Bles et al. 1976 \\
\hline & & & 1626 & 161025 & 428730 & Scholten et al. 1990 \\
\hline & Onbekend & $\mathrm{O}$ & 1954 & 144696 & 429023 & $\begin{array}{c}\text { Salm, C. van der et al. } \\
2006\end{array}$ \\
\hline \multirow{3}{*}{$\begin{array}{l}\text { Eolische en } \\
\text { fluvio- } \\
\text { periglaciale } \\
\text { afzettingen } \\
\quad-400\end{array}$} & \multirow{2}{*}{$\begin{array}{l}\text { Zeer fijn tot } \\
\text { matig fijn } \\
\text { zand }\end{array}$} & \multirow[b]{2}{*}{$\mathrm{O}$} & 27,28 & 223693 & 459325 & Kleijer, 2000 \\
\hline & & & 119 & 179343 & 464441 & $\begin{array}{l}\text { Elbers et al. 1996; } \\
\text { Lynden, } 1958\end{array}$ \\
\hline & Onbekend & $\mathrm{O}$ & 1948 & 180200 & 445630 & Intern \\
\hline \multirow{3}{*}{$\begin{array}{l}\text { Overige } \\
\text { afzettingen } \\
-600\end{array}$} & \multirow{2}{*}{ Siltige leem } & $B$ & 812 & 182679 & 327589 & Leenders, 1993 \\
\hline & & $\mathrm{O}$ & 804 & 182715 & 327645 & Leenders, 1993 \\
\hline & Onbekend & B & 1936, 1952 & 246880 & 437200 & $\begin{array}{c}\text { Kleijer et al. } 1998, \\
\text { Van Bakel et al. } 2007\end{array}$ \\
\hline Onbekend & $\begin{array}{l}\text { Zandige } \\
\text { veen en } \\
\text { veen }\end{array}$ & $\mathrm{O}$ & 1859 & 227000 & 556000 & Hamming, 1961 \\
\hline
\end{tabular}

a) MIN = Monster Identificatie Nummer. 


\section{$4 \quad$ Discussie}

\subsection{Rapport en database}

Van de bodemhydrofysische (BhF-) data die via dit project zijn gegenereerd, zijn de belangrijkste gegevens in dit rapport in tabel- en grafiekvorm opgenomen:

- ID-naam

- Afzettingsmilieu

- Textuurklassenaam

- Boven- of Ondergrond

- Coördinaten

- Monsternamedatum

- Monsterdiepte

- Standaardpuntencode (profielbeschrijving)

- Grondwatertrap

- Gemiddeld Hoogste en Gemiddeld Laagste Grondwaterstand (GHG en GLG)

- Textuurverdeling op gewichtsbasis van de minerale delen

- Droge bulkdichtheid

- Gloeiverlies (organische stof)

- Gemeten verzadigde waterdoorlatendheid

- Gemeten waterretentiekarakteristiek (RK)

- Afgeleide waterdoorlatendheidskarakteristiek (DK)

- Afgeleide Mualem-Van Genuchten-parameters

De hydrofysische gegevens zijn in het rapport alleen opgenomen door middel van de MualemVan Genuchten-parameters en de bijbehorende grafieken, omdat de retentiekarakteristiek en onverzadigde waterdoorlatenheden eenvoudig zijn af te leiden met behulp van de vergelijkingen in Bijlage 1.

Voor uitgebreidere gegevens kan de BIS-database worden geraadpleegd. Daarin zijn nog meer gegevens opgenomen, zoals landgebruik, profielbeschrijvingen, ruwe meetdata, volumetrische vochtgehalten en waterdoorlatenheden bij verschillende drukhoogten, berekende organische stofgehalten, monsternamen van de verschillende methoden, afgeleide gegevens en meer.

\subsection{Gebruiksadvies}

\subsubsection{Aandachtspunten}

De verkregen informatie kan gebruikt worden voor het opstellen van stromingsmodellen waarin de bodemhydrofysische informatie van een bepaalde opschalingseenheid wordt gekoppeld aan een verwante horizont dat in een bodemprofiel voorkomt. Vaak worden daarvoor afgeleide gegevens, bijvoorbeeld de Mualem-Van Genuchten-parameters, gebruikt. In de toekomst zullen deze naar verwachting vervangen worden door het PDI-parameters (Iden et al. 2014). Bij het gebruik van de gegevens in stromingsmodellen is het van belang in te zien dat:

a. De afgeleide gegevens vaak informatie bevatten in een bereik dat groter is dan dat van de oorspronkelijke meetdata. Feitelijk is er extrapolatie van de gegevens uitgevoerd die buiten het fysieke meetbereik tot onzekere resultaten kan leiden.

b. De Mualem-Van Genuchten-parameters bevatten een rekenkundig verzadigde waterdoorlatendheid die vaak veel kleiner is dan de werkelijk gemeten verzadigde waterdoorlatendheid. Dit komt omdat de verdampingsmethode over het algemeen alleen betrouwbare doorlatendheden geeft bij drukhoogten kleiner dan $-50 \mathrm{~cm}$. De MvG-fit is dan ook 
voornamelijk op die punten gebaseerd. De macroporiën in het monster, die het gedrag in het erg natte deel bepalen, kunnen in de opstelling voor de verzadigde doorlatendheid wel worden beschouwd, maar in de verdampingsmethode niet. De MvG-vergelijkingen zijn onvoldoende in staat om deze discontinuïteit in het natte bereik te modelleren.

c. Er onvolkomenheden kunnen zitten in de werkelijke bodemprofielopbouw ten opzichte van de profielopbouw zoals die voorkomt op de bodemkaarten. Het is bijvoorbeeld mogelijk dat er plaatselijk dunne verdichte lagen in de bodem aanwezig zijn die de hydraulische eigenschappen, zoals capillaire opstijging van water uit het grondwater, kunnen tegenwerken.

d. Bodemhorizonten die homogeen worden verondersteld, inhomogeen zijn en feitelijk met meerdere aparte lagen gemodelleerd moeten worden.

\subsubsection{Fuzzy-classificatie}

De textuurklassen zijn momenteel hard gedefinieerd. Als een monster nog net in een bepaalde klasse valt, wordt deze toegekend aan deze klasse, terwijl hij feitelijk ook eigenschappen bezit van de naastliggende klasse. Om hieraan tegemoet te komen, is het mogelijk om gebruik te maken van een zogenaamde 'fuzzy-classificatie'. Dit houdt in dat de werkelijk aangetroffen textuurverdeling niet wordt ingedeeld in een textuurklasse met harde grenzen, maar een gewogen deelname aan verschillende textuurklassen zal bevatten. Een hoge weging geldt dan voor de textuurklasse waarmee hij de meeste verwantschap heeft en een lagere weging voor de naastliggende klassen. De weging kan bijvoorbeeld volgens een Gauss-kromme worden toegekend.

\subsection{Raadplegen bodemfysische data in BIS}

De gegevens in BIS zijn te bereiken door direct in te loggen bij de Oracle-database en met behulp van SQL-statements de benodigde gegevens te selecteren. Toegang wordt alleen verkregen nadat er door de beheerder van de database inloggegevens zijn verstrekt.

De eenvoudigste inlogprocedure is via de command-prompt van Windows (DOS-box, te openen via Windows \Accessories \Command Prompt). Om in te loggen, moet het volgende commando worden gegeven: SQLPLUS bisuser/bisuser@geo_scomp0628.world

Hierna zal de prompt SQL> in het venster verschijnen met de vraag om de persoonlijke inloggegevens. Na het inloggen kunnen SQL-commando's worden ingetypt.

Een andere methode is het gebruik van ArcMap. Via Layers \Add Data wordt een scherm geopend met "Connection to scomp0628.sde". Selecteer de gewenste file en voeg deze toe in linker veld. Vervolgens is de inhoud te openen met de rechtermuisknop.

Van de gegevens uit het BIS Nederland-project is bekend dat zij allemaal zijn ingevoerd onder projectnummer 5235655.29. Met behulp van deze code kan een overzicht worden verkregen van alle profielen die binnen dit project vallen. Uit deze gegevens kan vervolgens een monster geselecteerd worden waaraan bodemfysische bepalingen zijn uitgevoerd. De identificatie van zo'n monster wordt gegeven aan de hand van PFB_ID in tabel PFB_MONSTER.

Het zou te ver voeren om hier alle commando's te geven die gebruikt kunnen worden om gegevens uit BIS te selecteren. In het Technisch datamodel (De Groot, 2010) is hierover meer informatie beschikbaar. 


\section{$5 \quad$ Conclusies}

Dit project geeft een overzicht van het belang van een goede bodemhydrofysische datareeks, in combinatie met beschrijvende gegevens. Het heeft geresulteerd in het opnemen in BIS van

- 118 hoogwaardige, en in complete configuratie, nieuw gestoken en gemeten monsters uit de periode 2012-2016.

- 4 monsters waarvan geen verdampingsmonsters, maar wel aanvullende gegevens gemeten zijn, die gekoppeld kunnen worden aan andere bodemhydrofysische gegevens in BIS.

- 44 oude monsters die in Priapus als 'goed' waren gekenmerkt. Deze monsters zijn in BIS opgenomen en gekoppeld aan de daar al aanwezige metagegevens. Van deze monsters ontbreken nog textuur en andere gegevens in BIS. Voor zover beschikbaar worden deze extra gegevens in een vervolgtraject alsnog toegevoegd.

- 10 hoogwaardige, oudere verdampingsmonsters uit Priapus, waarvan de afgeleide berekende gegevens in Priapus als 'slecht' waren gekenmerkt. De ruwe gegevens zijn echter met de nieuw ontwikkelde software en inzichten opnieuw doorgerekend en vervolgens alsnog als 'goed' gekenmerkt. De in BIS opgenomen monsters zijn, daar waar beschikbaar, uitgebreid met textuuren/of andere gegevens.

In totaal zijn dus 172 verdampingsmonsters plus 4 aanvullende, maar onvolledige, metingen gecombineerd met profieldata en andere beschrijvende data in BIS opgenomen. De nieuwe monsterlocaties zijn gericht geselecteerd aan de hand van een prioritering die door Knotters et al. (2011) is voorgesteld. Bij de opzet is uitgegaan van de Latin Hypercube Sampling, waarbij rekening gehouden wordt met het feit dat niet alle opschalingseenheden steekproefpunten bevatten ('empty domains'). Bij de bemonstering is getracht zo veel mogelijk klassen naar boven- en ondergrond, afzettingsmilieu, textuur en gehalte aan organische stof in BRO/BIS op te nemen, met ten minste twee monsters per klasse. Meerdere monsters per klasse zijn nodig om de nauwkeurigheid van geschatte gemiddelden te kunnen kwantificeren of om benaderingen, waarbij wordt geloot uit bodemhydrofysische karakteristieken, voor individuele locaties mogelijk te maken (bootstrapping). Van de nieuwe monsters zijn alle in hoofdstuk 4.1 genoemde bodemhydrofysische gegevens verzameld. Van de oude Priapus-monsters ontbreken helaas vaak een of meerdere gegevenstypen, maar zijn de waterretentie- en waterdoorlatendheids-karakteristieken altijd aanwezig.

Aanvullend heeft dit project geresulteerd in een 'zachte' koppeling tussen 53 bestaande hoogwaardige monsters in Priapus en bestaande beschrijvende data in de literatuur. Door deze koppeling wordt het onderbrengen van de data in BIS/BRO in een later stadium vergemakkelijkt.

De drukhoogten, vochtgehalten en tijd van de verschillende meetmethoden en de verzadigde waterdoorlatendheden zijn gebruikt voor het bepalen van afgeleide bodemhydrofysische eigenschappen en de Mualem-Van Genuchten-parameters. Daarbij is in dit project een Excelrekensheet ontwikkeld dat op een veel kleiner detailniveau de fitprocedure kan analyseren, waardoor eventuele afwijkingen beter op hun waarde geschat kunnen worden. In de bijlagen is een uitgebreidere weergave van het Excelprogramma gegeven. Tevens is een filter ontwikkeld waarmee de grote databestanden, afkomstig van het laboratorium, worden gereduceerd tot een veel kleinere dataset. Kleine schommelingen in de data (ruis) zorgen normaliter voor grote afwijkingen in de afgeleide data van met name de onverzadigde waterdoorlatendheid in het natte traject. Het filter zorgt er tevens voor dat minder last wordt ondervonden van deze variaties. In het filter worden geen data aangepast, alleen selectief volgens een vast protocol weggelaten.

Er zijn meerdere manieren mogelijk waarop bodemhydrofysische gegevens verzameld en geïnterpreteerd kunnen worden. De verschillende manieren leiden tot verschillende resultaten. Vanuit Wageningen Environmental Research WEnR/Alterra) wordt een eenduidige werkwijze zo veel mogelijk nagestreefd. Dit heeft geleid tot het interne document "Bodemhydrofysische gegevens: Voorkeursmethode" (Heinen en Bakker, 2016). 
Zoals beoogd, zijn alle opschalingseenheden nu gevuld met gegevens van twee locaties per opschalingseenheid, met uitzondering van de eolische, zeer fijn zand-afzetting, waarvan slechts één monster aanwezig is. Vanwege de nauwkeurig uitgevoerde selectie voorafgaand aan de bemonsteringen, zijn vrijwel alle gewenste opschalingseenheden nu aangetroffen en bemonsterd. Slechts een klein aantal opschalingseenheden is niet met twee locaties gevuld. Er is namelijk geen volledige garantie te geven dat de op de bodemkaart aangegeven bodemprofielen ook daadwerkelijk in het veld worden aangetroffen.

Aanbevolen wordt om in een vervolgopdracht:

- de 44 oude hoogwaardige monsters uit te breiden met overige bekende en gerelateerde gegevens in BIS, zoals textuur, dichtheid en dergelijke;

- ten minste één extra monster toe te voegen voor de eolische zeer fijn zand-afzetting;

- de haalbaarheid te onderzoeken voor het onderbrengen van de 53 overige oude Priapus-monsters;

- op basis van een nieuwe prioritering, waarin het areaal en spreiding van de gronden en de al aanwezige hoeveelheid gegevens wordt beschouwd, een aanvullende bemonstering uit te voeren. 


\section{Literatuur}

Bakel, P.J.T. van, J. Huinink, H. Prak en F. van der Bolt, 2005. HELP-2005. Uitbreiding en actualisering van de HELP-tabellen ten behoeve van het WATERNOOD-instrumentarium. Utrecht, Stowa/DLG/Alterra/LNV, Stowa-rapport 2005-16.

Bakel, P.J.T. van, H.T.L. Massop en A.J. van Kekem, 2007. Locatiekeuze ten behoeve van het onderzoek naar bemestingsvrije perceelranden; Hydrologische en bodemkundige karakterisering van de proeflocaties. Alterra-rapport 1457.

Bakker, G., M. Heinen, J.G. Wesseling, W.J.M. de Groot, F.B.T. Assinck, E.W.J. Hummelink, 2015. Bodemfysische gegevens in BIS. Wageningen, Alterra Wageningen UR (University \& Research centre), Alterra-rapport 2613.

Belitz, K. and S.P. Phillips, 1993. Numerical simulation of ground-water flow in the central part of the western San Joaquin Valley, California: U.S. Geological Survey Water-Supply Paper 2396, 69p.

Bles, B.J. en H.J.M. Zegers, 1969. De bodemgesteldheid van het Ruilverkavelingsgebied Lopikerwaard-West. Stiboka-rapport 806.

Bles, B.J., 1975. Ruilverkaveling St. Oedenrode: bodemgesteldheid en bodemgeschiktheid. Wageningen, Stiboka-rapport 1043.

Bles, B.J. en A.G. Beekman, 1976. Ruilverkaveling St. Oedenrode II: aanvullend bodemkundig onderzoek. Wageningen, Stiboka-rapport 1224.

Beuving, J. en J.J.H. van den Akker, 1996. Maaivelddaling van veengrasland bij twee slootpeilen in de polder Zegvelderbroek; vijfentwintig jaar zakkingsmetingen op het ROC Zegveld. Wageningen, SC-DLO, Rapport 377.

Cnossen, J. en P.C. Kuyer, 1965. De bodemgesteldheid en de tuinbouwkundige geschiktheid van de gronden in de ruilverkaveling Berlikum. Wageningen, Stiboka-rapport 654.

Dam, J.C. van, P. Groenendijk, R.F.A. Hendriks and J.G. Kroes, 2008. Advances of modeling water flow in variably saturated soils with SWAP. Vadose Zone J., Vol.7, No.2.

Hooghart, H., 2011. Veel gestelde vragen en antwoorden over de Basisregistratie Ondergrond, BRO.

Dirksen, C., 1991. Unsaturated hydraulic conductivity. In: K.A. Smith and C.E. Mullins (Eds.): Soil Analysis, Physical Methods. Marcel Dekker, Inc., New York, p.209-269.

Dodewaard, E. van, 1997. De bodemgesteldheid van de landinrichtingsgebieden Zuidwolde-Zuid, Beneden-Egge en Zuidwolde-Noord: resultaten van een bodemgeografisch onderzoek. Wageningen, DLO-Staring Centrum. Rapport 535.

Durner, W., 1992. Predicting the unsaturated hydraulic conductivity using multi-porosity water retention curves. In: M. Th. van Genuchten, F.J. Leij, and L.J. Lund (eds.), Proc. Int. Workshop, Indirect Methods for Estimating the Hydraulic Properties of Unsaturated Soils. pp. 185-202, University of California, Riverside.

Ebbers, G. en J.C. Pape, 1967. De bodemgesteldheid van het Ruilverkavelingsgebied Borculo. Stiboka-rapport 720.

E/CN, 2016. Report of the Inter-Agency and Expert Group on Sustainable Development Goal Indicators. E/CN.3/2016/2/rev.1, Annex IV.

Elbers, J.A., A.J. Dolman, E.J. Moors en W. Snijders, 1996. Hydrologie en waterhuishouding van bosgebieden in Nederland. Fase 2: Meetopzet en eerste resultaten. DLO - Staring Centrum, Rapport 333.2.

Genuchten, M.Th. van, 1980. A Closed-form Equation for Predicting the Hydraulic Conductivity of Unsaturated Soils. Soil Sci. Soc. Am. J. 44:892-898.

Genuchten, M.Th. van, F.J. Leij and S.R. Yates, 1991. The RETC code for quantifying the hydraulic functions of unsaturated soils. USDA, US Salinity Laboratory, Riverside, CA.

Gonzalez-Morales, Luis, Yu-Chieh Hsu, Jennifer Poole, Benjamin Rae, Ian Rutherford, 2014. A World That Counts. Mobilising the data revolution for sustainable development. Report prepared at the request of the United Nations Secretary-General, by the Independent Expert Advisory Group on a Data Revolution for Sustainable Development.

Groot, H. de, 2010. Technisch Datamodel van BIS en LSK versie 7.2 en gebruik in ARCGIS. Alterra, Wageningen, $31 \mathrm{p}$. 
Halbertsma, J.M. and G.J. Veerman, 1994. A new calculation procedure and simple set-up for the evaporation method to determine soil hydraulic functions. Rep. 88. DLO Winand Staring Centre, Wageningen, The Netherlands.

Halbertsma, J., 1996. Wind's evaporation method, determination of the water retention characteristics and unsaturated hydraulic conductivity of soil samples: possibilities, advantages and disadvantages. Advanced methods to determine hydraulic properties of soils: extended abstracts of the European workshop, Germany, June 10-12, 1996.

Hamming, C., 1961. De bodemgesteldheid van het ruilverkavelingsgebied Smilde. Wageningen, Stiboka-rapport 521.

Heinen, M. and P. de Willigen, 1998. FUSSIM2. A two-dimensional simulation model for water flow, solute transport and root uptake of water and nutrients in partly unsaturated porous media, Quantitative Approaches in Systems Analysis No. 20, AB-DLO and PE, Wageningen, The Netherlands, 140 p.

Heinen, M. en G. Bakker, 2016. User Manual Analysing the Wind Evaporation Data. Interne notitie. Wageningen Environmental Research (Alterra).

Heinen, M. en G. Bakker, 2016. Bodemhydrofysische gegevens: voorkeursmethode. Interne notitie. Wageningen Environmental Research (Alterra).

Hemker, C.J. en R.G. de Boer, 1997. MicroFEM Version 3.60.66. Amsterdam.

Hendriks, R.F.A., van den Akker en Hummelink, 2008. Inverse modellering van verticaleinfiltratieproeven op de Waddenzeedijk bij de Boonweg. Alterra-rapport 1833.

Hoogewoud, J.C., J.C. Hunink, G.F. Prinsen, A.A. Veldhuizen en J. Verkaik, 2013. Veranderingsrapportage NHI 3.0. Beschrijving van de veranderingen in versie 3.0. Deltares.

Hoving, I.E. en G.L. Velthof, 2006. Landbouw- en milieukundige effecten van graslandvernieuwing op zand- en kleigrond. Praktijkrapport Rundvee 83.

Iden, S. and W. Durner, 2014. Comment to "Simple consistent models for water retention and hydraulic conductivity in the complete moisture range" by A. Peters. Water Resources Research 50: 7530-7534.

ISO 11272 First edition, 1998. Soil quality - Determination of dry bulk density

ISO 11274 First edition, 1998. Soil quality - Determination of the waterretention characteristic Laboratory methods.

ISO 11275,2004 . Soil quality - Determination of unsaturated hydraulic conductivity and water retention characteristic- Wind's evaporation method.

ISO 11277 Second edition, 2009. Soil quality - Determination of particle size distribution in mineral soil material - Method by sieving and sedimentation.

ISO 11461,2001 . Soil quality - Determination of soil water content as a volume fraction using coring sleeves - Gravimetric method.

Kamping, G. en J.A. van de Hurk, 1968. De bodemgesteldheid van het ruilverkavelingsgebied De Marne. Wageningen, Stiboka-rapport 715.

Kleijer, H. en J.A.M. ten Cate, 1998. De bodemgesteldheid van het herinrichtingsgebied WinterswijkOost; resultaten van een bodemgeografisch onderzoek. Wageningen, SC-DLO, Rapport 603.

Kleijer, H., 2000. De bodemgesteldheid van de gebieden Berkeldal, Graafschap, Wildenborch, Warnsveld-Vierakker en Hummelo-Keppel: resultaten van een bodemgeografisch onderzoek. Wageningen, Alterra-rapport 90.

Klungel, A.E., 1970. De bodemgesteldheid van de proefboerderij Ebelsheerd c.a. Wageningen, Stiboka-rapport 892.

Klute, A., 1972. The determination of the hydraulic conductivity and diffusivity of unsaturated soils. Soil Sci. 113, 264-276.

Knotters, M. en P.C. Jansen, 2004. Drempel-niet-lineariteit in ondiepe grondwaterregimes. Rapport 981.

Knotters, M., D.J. Brus, S.J.E. Verzandvoort en M. Heinen, 2011. Aanvullende bodemfysische gegevens voor BIS-Nederland. Wageningen, Alterra, Alterra-rapport 2245.

Leenders, W.H., 1992. De bodemgesteldheid van het herinrichtingsgebied de Leijen-West. Rapport 214.

Leenders, W.H., 1993. De bodemgesteldheid van drie stroomgebieden voor het erosienormeringsonderzoek Zuid-Limburg: resultaten van een bodemgeografisch onderzoek. Wageningen, DLO-Staring Centrum. Rapport 270.

Leenders, W.H., 1999. Bodemkundig-Hydrologisch onderzoek De Vlietpolder. Alterra-rapport 693. 
Leij, F.J., M.Th. van Genuchten, S.R. Yates and W.B. Russell, 1992. RETC: a computer program for analyzing soil water retention and hydraulic conductivity data. In: M. Th. van Genuchten, F.J. Leij, and L.J. Lund (eds.), Proc. Int. Workshop, Indirect Methods for Estimating the Hydraulic Properties of Unsaturated Soils. pp. 263-272, University of California, Riverside.

Lynden, K.R. van, 1958. De bodemgesteldheid van de boswachterij Kootwijk. Wageningen, Stibokarapport 493.

Mualem, Y., 1976. A new model for predicting the hydraulic conductivity of unsaturated porous media. Israel. Water Resources Research, Vol. 12, No. 3.

NEN 5709, ICS 13.080.10, 2006. Bodem - Monstervoorbehandeling voor de bepaling van organische en anorganische parameters in grond.

NEN 5753 en 5753/C1, ICS 13.080.20, 2006 en 2009. Bodem - Bepaling van het lutumgehalte en de korrelgrootteverdeling in grond en waterbodem met behulp van zeef en pipet.

NEN 5754, 1992. Bepaling van het gehalte aan organische stof in grond volgens de gloeiverliesmethode.

NEN 5789, 1991. Bepaling van de verzadigde waterdoorlatendheid.

Pastoors, M.J.H., 1992. Landelijk Grondwater Model; conceptuele modelbeschrijving (National Groundwater Model; description of model concept). RIVM-report no. 7143050004, Bilthoven, The Netherlands.

Pertassek, T., A. Peters and W. Durner, 2011. HYPROP Data Evaluation Software User's Manual, V.1.0, UMS GmbH, München, Germany.

Peters, A. and W. Durner, 2008. Simplified evaporation method for determining soil hydraulic properties. Journal of Hydrology 356: 147-162.

Peters, A. 2013. Simple consistent models for water retention and hydraulic conductivity in the complete moisture range. Water Resources Research 49: 6765-6780.Prince, K.R., O.L. Franke and T.E. Reilly, 1988. Quantitative assessment of the shallow ground-water flow system associated with Connetquot Brook, Long Island, New York: U.S. Geological Survey Water-Supply Paper 2309, $28 p$.

Ploumen, E.M.J., 2016. Nederland Ontwikkelt Duurzaam: Plan van aanpak inzake implementatie SDGs. Brief van de Minister voor Buitenlandse Handel en Ontwikkelingssamenwerking aan de Tweede Kamer. 's-Gravenhage, kst-26485-232.

Riele, W.J.M. te en B.H. Steeghs, 1968. De bodemgesteldheid van het ruilverkavelingsgebied Zevenbergen. Stiboka-rapport 722.

Salm, C. van der, J. Dolfing, J.W. van Groenigen, M. Heinen, G. Koopmans, J. Oenema, M. Pleijter en A. van den Toorn, 2006. Diffuse belasting van oppervlaktewater met nutriënten uit de veehouderij; Monitoring van nutriëntenverliezen uit grasland op zware klei in Waardenburg. Wageningen, Alterra, Alterra-rapport 1266.

Scholten, A., F. Brouwer, M. Knotters en H.R.J. Vroon, 1990. De bodemgesteldheid van het landinrichtingsgebied Land van Maas en Waal : resultaten van een bodemgeografisch onderzoek. Wageningen, DLO-Staring Centrum. Rapport 35.

Šimůnek, J., M. Sejna and M.Th. van Genuchten, 1999. The Hydrus-2D software package for simulating two-dimensional movement of water, heat, and multiple solutes in variably saturated media. Version 2.0, IGWMC - TPS - 53, International Ground Water Modeling Center, Colorado School of Mines, Golden, Colorado, 251pp.

Šimůnek, J., M. Šejna, H. Saito, M. Sakai and M.Th. van Genuchten, 2008. The Hydrus-1D Software Package for Simulating the Movement of Water, Heat, and Multiple Solutes in Variably Saturated Media, Version 4.0, HYDRUS Software Series 3, Department of Environmental Sciences, University of California Riverside, Riverside, California, USA, pp. 316.

Sluys, P. van der, 1956. Rapport betreffende de bodemgesteldheid van Tielerwaard-West. Wageningen, Stiboka-rapport 436.

Tiktak, A., F. van den Berg, J.J.T.I. Boesten, M. Leistra, A.M.A. van der Linden and D. van Kraalingen, 2000. Pesticide Emission Assessment at Regional and Local Scales: User Manual of FOCUS Pearl version 1.1.1. RIVM Report 711401008, Alterra-report 28, RIVM, Bilthoven, 142 pp.

Tiktak, A., A.M.A. van der Linden and J.J.T.I. Boesten, 2003. The GeoPEARL model. Model description, applications and manual RIVM Report 716601007/2003, RIVM, Bilthoven, 79 pp.

Tiktak, A., A.M.A. van der Linden, J.J.T.I. Boesten, R. Kruijne and D. van Kraalingen, 2004. The GeoPEARL model. Part II. User Guide and model description update. RIVM-report 716601008/2004. RIVM, Bilthoven, The Netherlands. 
Verzandvoort, S.J.E., H.R.J. Vroon, J.G. Wesseling, G. Bakker, K. Oostindie, G.H. Stoffelsen, A.H. Heidema en G.B.M. Heuvelink, 2012. Naar een database van bodemhydraulische karakteristieken voor Nederland. Wageningen, Alterra, Alterra-rapport 2238.

Vogel, T., K. Huang, R. Zhang and M.Th. van Genuchten, 1996. The HYDRUS code for simulating onedimensional water flow, solute transport, and heat movement in variably-saturated media, Version 5.0, Research Report No 140, U.S. Salinity Laboratory, USDA, ARS, Riverside, CA.

Vos, J.A. de, 1997. Water flow and nutrient transport in a layered silt loam soil. Doctoral Thesis, Wageningen Agricultural University, Wageningen, The Netherlands, $287 \mathrm{p}$.

Walsum, P.E.V. van, A.A. Veldhuizen and P. Groenendijk, 2010. SIMGRO 7.1.0, Theory and model implementation. Wageningen, Alterra, Alterra-report 913.1. 93pp.

Watson, K.K., 1966. An instantaneous profile method for determining the hydraulic conductivity of unsaturated porous materials. Water Resour. Res2, 709-715.

Wendroth, O., W. Ehlers, J.W. Hopmans, J. Halbertsma and J.H.M. Wösten, 1993. Reevaluation of the evaporation method for determining hydraulic functions in unsaturated soils. Soil Science Society of America journal, Volume 57, Issue 6, Pages: 1436-1443.

Wesseling, J.G., H.R.J. Vroon en F. Brouwer, 2013. Het Titanen-project. Een set software-tools voor het verwerken van veld- en labgegevens. Alterra-rapport (in voorbereiding).

Wolf, J., A.H.W. Beusen, P. Groenendijk, T. Kroon, R. Röttera and H. van Zeijts, 2003. The integrated modeling system STONE for calculating nutrient emissions from agriculture in the Netherlands. Environmental Modelling \& Software, Volume 18, Issue 7, Pages 597-617.

Wösten, J.H.M., J.H. Bannink en J. Beuving. 1987. Waterretentie- en doorlatendheidskarakteristieken van boven- en ondergronden in Nederland: de Staringreeks. Wageningen. Stiboka-rapport 1932, ICW-rapport 18.

Wösten, J.H.M., F. de Vries, J. Denneboom en A.F. van Holst, 1988. Generalisatie en bodemfysische vertaling van de bodemkaart van Nederland, 1:250000, ten behoeve van de PAWN-studie. Stiboka, Wageningen. Rapport 2055.

Wösten, J.H.M., G.J. Veerman en J. Stolte, 1994. Waterretentie- en doorlatendheidskarakteristieken van boven- en ondergronden in Nederland: de Staringreeks. Vernieuwde uitgave 1994. Wageningen, Staring Centrum-DLO, Technisch Document 18.

Wösten, J.H.M., G.J. Veerman, W.J.M de Groot en J. Stolte, 2001. Waterretentie- en doorlatendheidskarakteristieken van boven- en ondergronden in Nederland: de Staringreeks. Vernieuwde uitgave 2001. Wageningen, Wageningen UR-Alterra. Alterra-rapport 153, ISSN 1566-7197.

Wösten, J.H.M., F. de Vries, T. Hoogland, H.T.L. Massop, A.A. Veldhuizen, H.R.J. Vroon, J.G. Wesseling, J. Heijkers en A. Bolman, 2012. BOFEK2012, de nieuwe, bodemfysische schematisatie van Nederland. Wageningen, Alterra, Alterra-rapport 2387. 88 blz. 


\section{Bijlage 1 Excelfilter en fit-programma}

Het Excelprogramma dat is gebruikt om de puntenwolk van de verdampingsmethode en vervolgens de uiteindelijke Mualem-Van Genuchten-fit (MVG-fit) af te leiden, is gedurende dit project door de eerste twee auteurs ontwikkeld in 2012-2014 en is verder doorontwikkeld in 2016. In 2016 heeft dit tevens geleid tot de ontwikkeling van een filter, dat voorafgaand aan de (pre)fit wordt gebruikt om de grote hoeveelheid ruwe data van de meetopstelling te reduceren.

Aanleiding voor het ontwikkelen van nieuwe programmatuur was de wens om gedurende het fit-proces gedetailleerd inzicht te krijgen in de tussenresultaten en om onbetrouwbare meetpunten van de verdampingsmethode te kunnen verwijderen of meetpunten van aanvullende apparatuur toe te kunnen voegen en de effecten hiervan gedetailleerd te kunnen bestuderen. De opzet via een Excelrekensheet biedt tevens kansen om op eenvoudige wijze op gebruikersniveau in- en uitvoer aan te passen, toe te voegen of te verwijderen. Bestaande software, zoals RETC (van Genuchten et al. 1991; Leij et al. 1992), Appia (Halbertsma, 1994) en HYPROP (Pertassek et al. 2011), voeren veel berekeningen op de achtergrond uit zonder dat de gebruiker tussenresultaten kan inzien. Bovendien zijn er in de programmatuur beperkingen opgelegd in het aantal meetpunten, het aantal tensiometers en is de invoer niet altijd gebruiksvriendelijk. Vooral de van de ruwe verdampingsdata afgeleide puntenwolk van de onverzadigde doorlatendheid moet altijd kritisch door een expert worden beschouwd. Met name in het natte traject kunnen namelijk door modellering fouten ontstaan in de afgeleide gegevens vanwege beperkingen van het model, maar ook als gevolg van de meetnauwkeurigheid.

\section{Filter}

Datafiltering wordt uitgevoerd met een Microsoft Exceltoepassing. In deze eerste stap worden de ruwe gegevens, die rechtstreeks afkomstig zijn uit de laboratorium Verdampingssetup, gefilterd zodat ze geschikt zijn voor het Evap-fits-v3.xlsm-bestand (kort: E-fits-bestand). Het Evap-Filter-v8.xlsm filter (kort: E-filterfile) verandert geen gegevens, maar selecteert slechts een beperkt aantal records. Over het algemeen komen er uit het lab grote databestanden van enkele duizenden datarecords. In het lab wordt een kort meetinterval (1 minuut) gebruikt om inzicht te krijgen in de kortetermijntemperatuureffecten en de niet-evenwichttoestanden tijdens de metingen. Pas daarna kan een gerechtvaardigde reductie van metingen worden verricht. Wanneer een groter meetinterval wordt gebruikt, worden metingen op willekeurige wijze geëlimineerd, bijvoorbeeld eenmaal bij een temperatuurstijging en een willekeurig volgend moment gedurende een temperatuurverlaging. Dit resulteert in een grotere en onverklaarbare ruis dan bij een kort meetinterval. Filteren nadat met hoge frequentie is gemeten, heeft het grote voordeel dat gebruikgemaakt kan worden van de beschikbare informatie. Dit verbetert het eindresultaat. Doel van het E-filter is om een beheersbaar bestand met 30-1000 gegevenspunten over te houden. In dit uiteindelijke bestand zijn temperatuurinvloeden zo veel mogelijk geëlimineerd. Records die niet in evenwicht blijken te zijn tijdens de initiële fase van de metingen worden verwijderd, evenals records aan het einde van de metingen op het moment dat tensiometers gaan caviteren ('doorslaan'). Verder worden records gemarkeerd als zij potentieel onbetrouwbare afgeleide resultaten genereren in het E-Fitsprogramma. Dat is meestal het geval tijdens kleine veranderingen in het meetresultaat ten opzichte van een vorig meettijdstip. Gegevens voor doorlatendheidsberekeningen zijn namelijk zeer gevoelig voor lage dh/dz-gradiënten. De gegevens voor de $\theta(h)-$ berekeningen zijn daar veel minder gevoelig voor. Als in de $K-h-\theta$ prefit en definitieve fit alleen gegevens worden gebruikt die geschikt zijn voor doorlatendheidsberekeningen, wordt waardevolle informatie voor de retentiecurve weggelaten, vooral in het natte bereik. Aangezien dit niet wenselijk is, maken het E-filter en het nieuwe E-fitprogramma sinds 2016 onderscheid in deze gegevens. Dit onderscheid is in het E-filter en het E-Fitprogramma weergegeven door de codes 0-2. 
De ruwe data, die normaal gesproken bestaan uit een groot tekstbestand met duizenden meetpunten, worden onderworpen aan de volgende criteria:

a. De data worden gecheckt op winter- en zomertijdveranderingen en worden aangepast naar een continue tijdserie.

b. Bij elke tijdstap wordt een gemiddeld volumetrisch vochtgehalte berekend op basis van de gewichten, monstervolume en stoofdroge massa.

c. Foutieve begin- en eindwaarden worden verwijderd, bijvoorbeeld punten met een toenemend gewicht of zuigspanning tijdens het op evenwicht komen voor aanvang van de werkelijke meting en punten aan het eind van de meting waar tensiometers caviteren ('doorslaan').

d. Niet goed werkende tensiometers kunnen worden uitgeschakeld voor de complete serie. Ze worden als zodanig geïndiceerd, maar niet verwijderd. Ook kunnen afzonderlijke foutieve metingen als foutief worden geïndiceerd, zoals die kunnen optreden bij communicatieproblemen van de meetopstelling.

e. Vervolgens worden alleen datapunten geselecteerd voor verdere analyse als deze liggen binnen een aan te passen ruis-bandbreedte. Een veelvoorkomende vorm van ruis treedt bijvoorbeeld op door schommelende temperaturen.

f. Om ten behoeve van de berekening van de punten voor onverzadigde waterdoorlatendheid te kunnen voldoen aan een voldoende grote drukverandering tussen twee meetpunten en tussen twee tensiometers, wordt gecheckt op een instelbare minimale gradiëntwaarde (dh/dz). In combinatie met een instelbare minimale en maximale tijdspannen tussen twee metingen worden metingen geïndiceerd als zij potentieel resulteren in onnauwkeurige waarden voor de doorlatendheid.

g. De resterende dataset die het filter verlaat, heeft hetzelfde format als die nodig is voor de invoer van het Master Evap Fits V3.xIsm programma en bevat bij voorkeur 30-1000 records. Elk record is gecodeerd met 0,1 , of 2 , waarbij een enkele meting of een complete tensiometerreeks niet in de prefit en uiteindelijke RETC fit gebruikt moet worden (0), of alleen gebruikt moet worden voor de waterretentiekarakteristiek (1), of gebruikt moet worden voor zowel de waterretentie- als de waterdoorlatendheidskarakteristiek (2).

\section{Invoerscherm fitprogramma}

In Figuur B.1.1 is een indruk gegeven van het invoerscherm van de rekensheet. De gele cellen geven de mogelijkheid om de modaliteit van de prefit aan te passen (J7), de fit-optimalisatie uit te laten voeren op basis van de gemeten monstergewichten of de gemiddelde volumetrische vochtgehalten (F17) en de weegfactor (D19) aan te passen voor het vochtgehalte bij de start van de metingen of het eind van de metingen (F19). In rij $22 \mathrm{t} / \mathrm{m} 25$ zijn aanvullende vochtgehaltemetingen toe te voegen. Lager in het invoerscherm (Figuur B.1.2) zijn apart gemeten verzadigde doorlatendheden toe te voegen en is het mogelijk om de prefit uit te laten voeren op basis van 2, 3 of 4 tensiometermeetreeksen of om individuele metingen in de fit-procedure weg te laten. Verder is kolom $\mathrm{C}$ aangepast ten opzichte van de vorige versie:

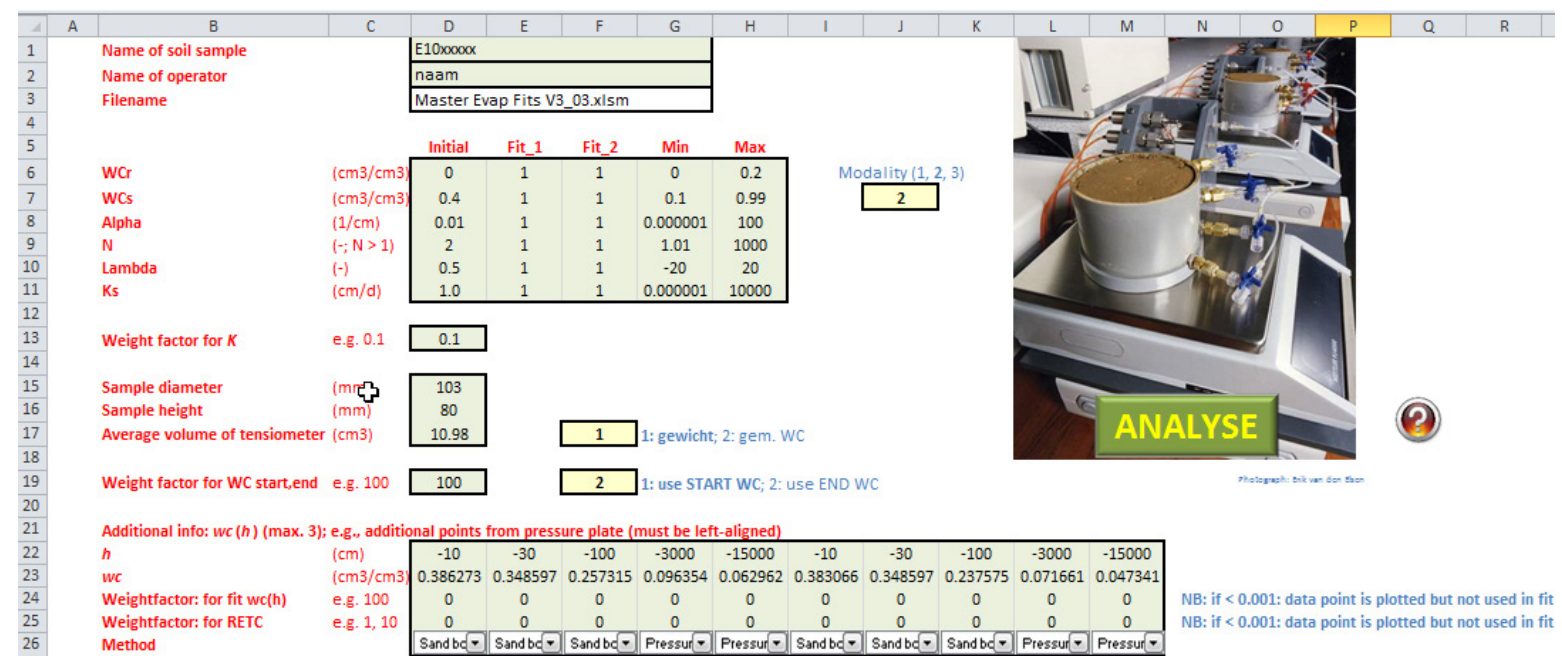

Figuur B.1.1 Bovenste deel van het invoerscherm van de Excelsheet. 


\section{Prefit - De eerste Van Genuchten-retentiefit}

De ruwe data die met de verdampingsopstelling worden gegenereerd, zijn vaak omvangrijk. Er is zeer frequent gemeten omdat de data, ondanks het feit dat de metingen in een goed geklimatiseerd lab (temperatuur $16+/-1^{\circ} \mathrm{C}$ ) uitgevoerd worden, een rimpel in het drukverloop bevatten die een functie is van de temperatuur. Deze rimpel is in het natte traject niet te verwaarlozen. Daarom worden de data dusdanig gefilterd dat er steeds een meetpunt wordt geselecteerd op hetzelfde punt van de flanken van de rimpel. Daarna worden de data nog verder ingekort, zodat uiteindelijk 50 tot 200 datapunten beschikbaar zijn. Er wordt alleen gewerkt met werkelijk gemeten data: er vindt geen middeling van metingen plaats.

De metingen van de drukhoogten en gemiddelde volumetrische vochtgehalten van het totale monster van de verdampingsmethode worden gebruikt om de Van Genuchten-retentiecurve voor de eerste keer te fitten. Deze gemiddelde fit wordt gebruikt om vochtgehalten te berekenen in elk compartiment van het bodemmonster, ofwel op elke hoogte van de tensiometers en op elk tijdstip. Door de berekende vochtgehalten per compartiment te vermenigvuldigen met het volume van het monstercompartiment, ontstaat een berekende hoeveelheid water per compartiment.

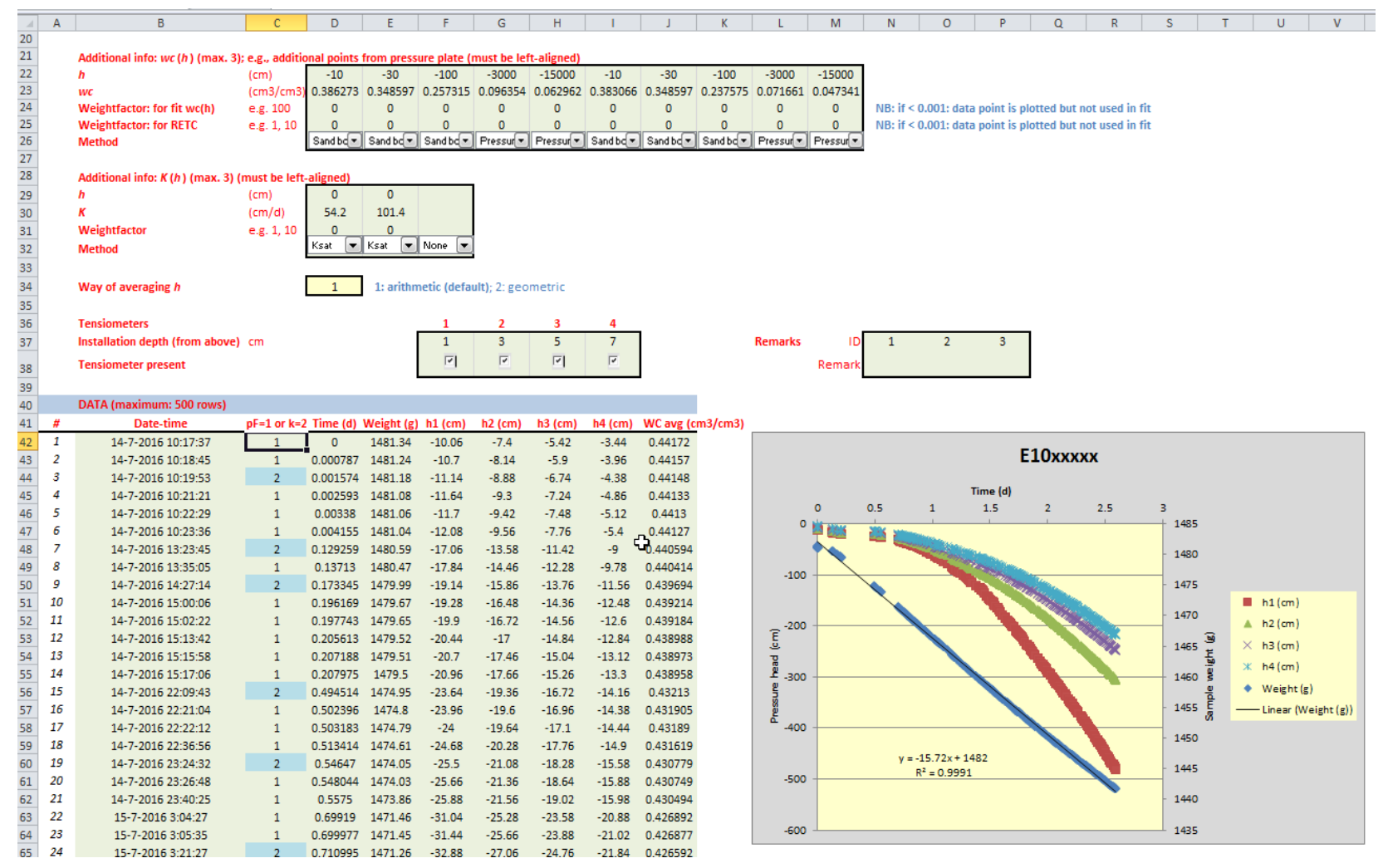

Figuur B.1.2 Onderste deel van het invoerscherm van de Excelsheet.

De som van deze hoeveelheden water moet gelijk zijn aan de totale gemeten hoeveelheid water in het monster. Als hierin een afwijking zit, worden de vochtgehalten van de retentiecurve aangepast. Op deze wijze wordt de fit door iteratie geoptimaliseerd. De prefits in dit project zijn, afhankelijk van de resultaten, uitgevoerd met een 1, 2 of 3 modale functie van Van Genuchten (1980) (cf. Durner, 1992).

De vorm van de waterretentiekarakteristiek volgens het k-modale Van Genuchten-model wordt bepaald met de volgende vergelijking:

$S_{e}=\sum_{i=1}^{k} w_{i}\left(\frac{1}{1+\left(\alpha_{i}|h|\right)^{n_{i}}}\right)^{m_{i}}$ 
waarin:

$k$ totale modaliteit (hier $k=1,2$ of 3 ) is gebruikt

$S_{e} \quad$ verzadigingsgraad, $S_{e}=\left(\theta-\theta_{r}\right) /\left(\theta_{s}-\theta_{r}\right)$ (dimensieloos)

$\theta \quad$ volumetrisch vochtgehalte $\left(\mathrm{L}^{3} \mathrm{~L}^{-3}\right)$ als functie van de drukhoogte $h$

$\theta_{r} \quad$ residueel vochtgehalte $\left(\mathrm{L}^{3} \mathrm{~L}^{-3}\right)$, gedefinieerd bij dat deel van de $\mathrm{pF}$-curve waar $\mathrm{d} h / \mathrm{d} \theta \rightarrow 0$, dus bijvoorbeeld bij pF $=4,2$ of $\mathrm{pF}=6$ (luchtdroog)

$\theta_{s} \quad$ verzadigd vochtgehalte $\left(\mathrm{L}^{3} \mathrm{~L}^{-3}\right)$, ofwel het vochtgehalte bij $h \rightarrow 0$

$a \quad$ vormparameter $\left(\mathrm{L}^{-1}\right)$, verschillende voor elke modaliteit $\left(\mathrm{cm}^{-1}\right)$; voor $k=1$ ongeveer gelijk aan $1 / h_{\text {plateau, }}$ ofwel de $h$ behorend bij het punt waar $d h / d \theta$ maximaal is

$n \quad$ vormparameter (-), verschillende voor elke modaliteit, stelt de steilheid van de retentiekarakteristiek voor bij kleine $\theta$; een grotere $n$ geeft een steilere grafiek bij kleine $\theta$ en daarmee een platter plateau

$m$ vormparameter, verschillende voor elke modaliteit, $m=1-1 / n$ (dimensieloos)

$h$ drukhoogte $(\mathrm{cm})$

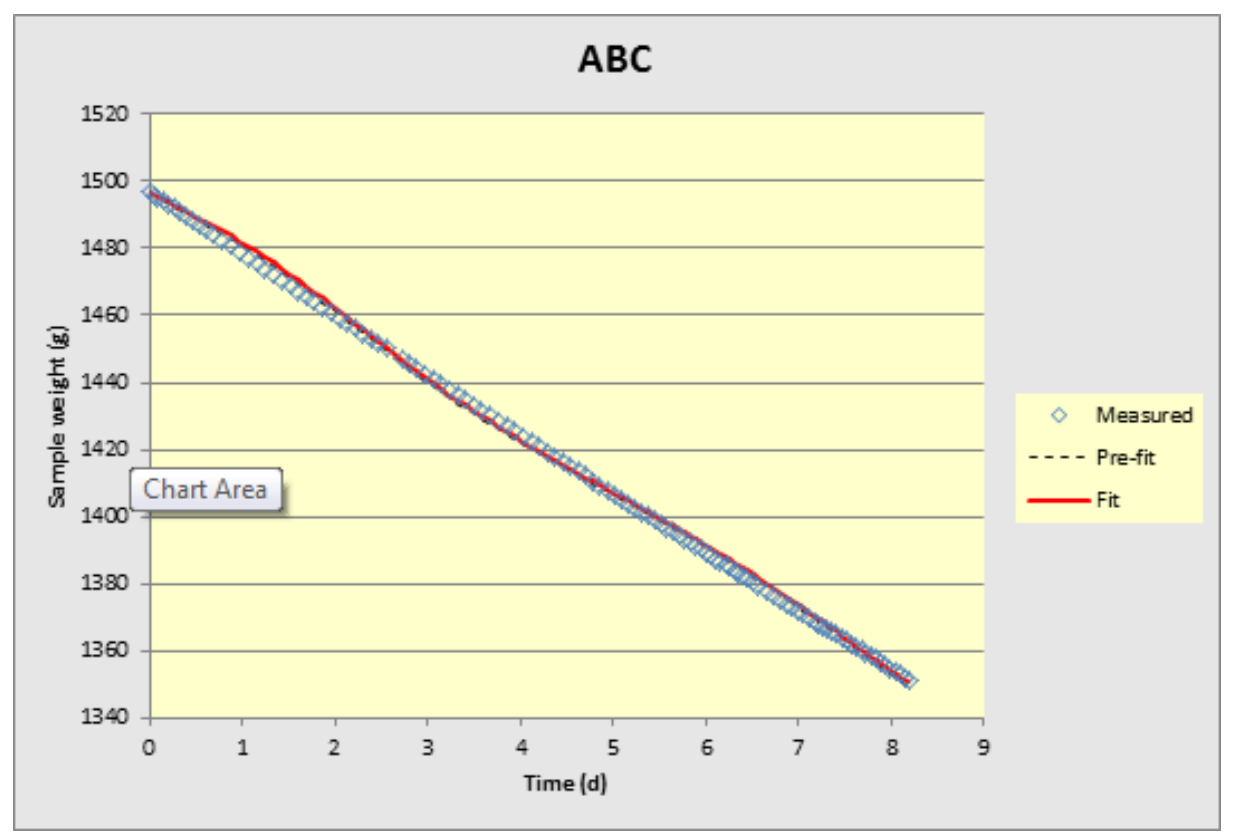

Figuur B.1.3 Vergelijkende figuur van de fysiek gemeten gewichten (blauwe punten), de berekende gewichten op basis van de retentiekarakteristiek van de prefit (zwarte stippellijn) en van de berekende uiteindelijke fit volgens Mualem-Van Genuchten (rode lijn) die door het Excelprogramma worden gegenereerd.

In eerste instantie is de prefit gedaan met een 1-modale fit $(k=1)$ en worden de extra metingen van de zandbak en andere opstellingen buiten beschouwing gelaten (weight factor for $w c(h)=0$ ), zodat de resultaten een $k$ - $h$-puntenwolk (onverzadigde waterdoorlatendheid) opleveren die alleen door de waarnemingen van de verdampingsmethode worden bepaald. Bij onvoldoende resultaten, met name wanneer de berekende gewichtsafname onvoldoende aansluit bij de gemeten gewichtsafname, wordt de modaliteit verhoogd. Figuur B.1.3 geeft een voorbeeld van het programma waarmee een dergelijke vergelijking visueel wordt gemaakt. De geoptimaliseerde prefit resulteert in termen voor de waterbeweging tussen de 4 bodemlagen in de tijd volgens de 'instantaneous profile method' (Watson, 1966; Klute, 1972; Dirksen, 1991). Met de vergelijking van Darcy worden daarmee voor elke set van 2 tensiometers de doorlatendheden als functie van de drukhoogte berekend, resulterend in 3 datasets van 3 tensiometerparen in het geval er 4 tensiometers bij de berekeningen worden gebruikt.

In het natte bereik kunnen in de praktijk door kleine meetfouten $\mathrm{d} h / \mathrm{d} z$-waarden resulteren in negatieve waarden van $k$ (indien $\mathrm{d} h / \mathrm{d} z<1$ ) of in waarden die grote uitschieters vertonen bij waarden van $\mathrm{d} h / \mathrm{d} z$ net groter dan 1 . Deze waarden worden in dit project als uitbijters beschouwd en niet meegenomen in de verdere analyse. Negatieve waarden voor $k$ worden in het programma automatisch 
verworpen door ze te markeren met een waarde van -999 (m/s). Uitbijters worden selectief door de gebruiker verwijderd door in de tussenresultaten te zoeken naar het meettijdstip waarop de uitbijter betrekking heeft en deze vervolgens in het invoerscherm uit te zetten. De uitbijters zitten normaliter in het natte meetgebied. In de literatuur wordt in deze context veelvuldig gewezen op de onzekere uitkomsten van $k$ - $h$-relaties in het natte gebied. Afhankelijk van de grondsoort is het in de praktijk daarom lastig om betrouwbare $k$ - $h$-relaties te vinden in het gebied $h=0$ tot $-50 \mathrm{~cm}$. Er zal daarom niet altijd een meting van de doorlatendheid berekend kunnen worden in het gebied $h=0$ tot $-10 \mathrm{~cm}$. Ook blijkt in de praktijk vaak dat het gebruik van een 1-modale functie onvoldoende is om het drukhoogtetraject in het natte bereik te beschrijven. Dit komt door de vaak (relatief) snelle daling van de drukhoogte in het hele natte gebied. In het half-natte gebied gaat deze weer over in een tragere daling en vervolgens in het droge gebied weer in een snellere daling.

De uiteindelijk gegenereerde drukhoogte $h$ (en daarmee ook de drukgradiënt $\mathrm{d} h / \mathrm{d} z$ ) die wordt weergegeven in de puntenwolken van de retentie- en doorlatendheidskarakteristiek, is een harmonisch (optioneel: geometrisch) gemiddelde drukhoogte op het grensvlak tussen 2 opeenvolgende tensiometers en 2 opeenvolgende tijdstippen. Dit geldt ook voor het vochtgehalte $\theta$.

Het debiet $q(\mathrm{~m} / \mathrm{s})$ dat, als gevolg van verdamping aan de bovenzijde van het monster, van onderen naar boven stroomt, wordt berekend op basis van de instantaneous profile method. De uiteindelijk berekende doorlatendheid $k(\mathrm{~m} / \mathrm{s})$ volgt uit de vergelijking van Darcy:

$k=\frac{q}{\frac{d h}{d z}-1}$

De aldus gegenereerde $\theta-h-K$ data zijn gebruikt in de uiteindelijke Mualem-Van Genuchten-fit.

\section{Uiteindelijke Mualem-Van Genuchten-fit}

Bij de uiteindelijke fit kunnen de metingen uit de zandbak-, drukpan- en verzadigde waterdoorlatendheidsmethode worden meegenomen in de berekening. De uiteindelijke Van Genuchten pF-curve kan afwijken van de prefit pF-curve, omdat de uiteindelijke fit geoptimaliseerd is in combinatie met de doorlatendheidsdata, terwijl de prefit alleen gebaseerd is op vochtgehalten en drukhoogten. Bovendien is de uiteindelijke fit een 1-modale fit, terwijl de prefit vaak een hogere modaliteit heeft. De vergelijkingen die gebruikt worden bij de MvG-fit zijn de vergelijkingen B.1 (met $k=1$ ) en B.3.

$K(h)=K_{S}^{S} \frac{\left[\left(1+|\propto h|^{n}\right)^{1-1 / n}-|\propto h|^{n-1}\right]^{2}}{\left(1+|\propto h|^{n}\right)^{(1-1 / n)(L+2)}}$

waarin:

$L: \quad$ Vormparameter (-) en stelt het verloop voor van $K(h)$ bij lage $h$, ofwel bij grote zuigspanningen. Hoe groter (minder negatief) de waarde van $L$, hoe steiler de grafiek van $K(h)$.

$K_{s}^{s}$ : $\quad$ Dit is de verzadigde waterdoorlatendheid van de fit. Deze waarde komt meestal niet overeen met de gemeten $K_{s}^{m}$, die normaliter (veel) groter is. Dit komt waarschijnlijk doordat de berekende doorlatendheid bij $h=0$ geen rekening houdt met de met water gevulde macroporiën. Randvoorwaarde: $K_{s}^{s}>0$. 


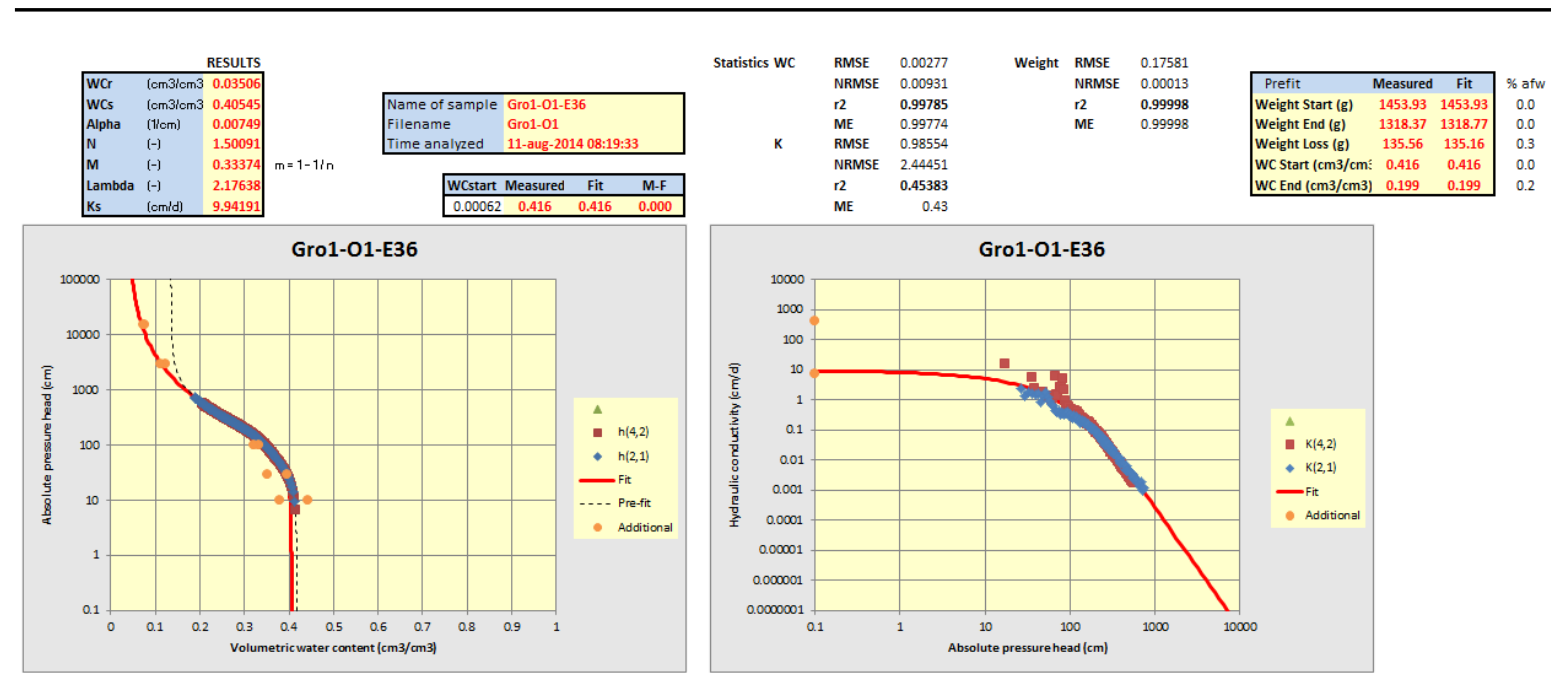

Figuur B.1.4 Screendump van de 'Results'-tab van het Excelprogramma. Links de retentiekarakteristiek, rechts de doorlatendheidskarakteristiek. Verder zijn de fit-parameters en enkele statistische gegevens weergegeven. 


\section{Bijlage 2 Grafieken van de meetgegevens (2012-2016)}

In de figuren van deze bijlage zijn links de retentie- en rechts de waterdoorlatendheidskarakteristieken gegeven van 2 duplomonsters (118 nieuwe, 10 oude, 4 onvolledige (10102, 10104, $10106,10110)$ ). De puntenwolken (blauwe kruisjes en rode open vierkantjes) zijn afkomstig uit de prefit van de verdampingsmethode. Verder zijn in de retentie-karakteristiek nog extra meetpunten opgenomen vanuit de zandbak- en drukpanmethode (groene stippen). In de doorlatendheidskarakteristiek zijn extra meetpunten opgenomen van de apart gemeten verzadigde waterdoorlatendheid (groene stippen). De retentie- en doorlatendheids-karakteristieken zijn per monster gefit met een enkele Mualem-Van Genuchten-fit. Dat betekent dat soms concessies zijn gedaan in de retentiecurve om de doorlatendheidscurve beter te kunnen fitten en vice versa. De Mualem-Van Genuchten-parameters bevatten een rekenkundig verzadigde waterdoorlatendheid die vaak veel kleiner is dan de werkelijk gemeten verzadigde waterdoorlatendheid. Dit komt omdat de verdampingsmethode over het algemeen alleen betrouwbare doorlatendheden geeft bij drukhoogten kleiner dan $-50 \mathrm{~cm}$. De MvG-fit is dan ook voornamelijk op die punten gebaseerd. De macroporiën in het monster, die het gedrag in het erg natte deel bepalen, kunnen in de opstelling voor de verzadigde doorlatendheid wel worden beschouwd, maar in de verdampingsmethode voor de onverzadigde waterdoorlatendheid niet. De MvG-vergelijkingen zijn onvoldoende in staat om deze discontinuïteit in het natte bereik te modelleren.
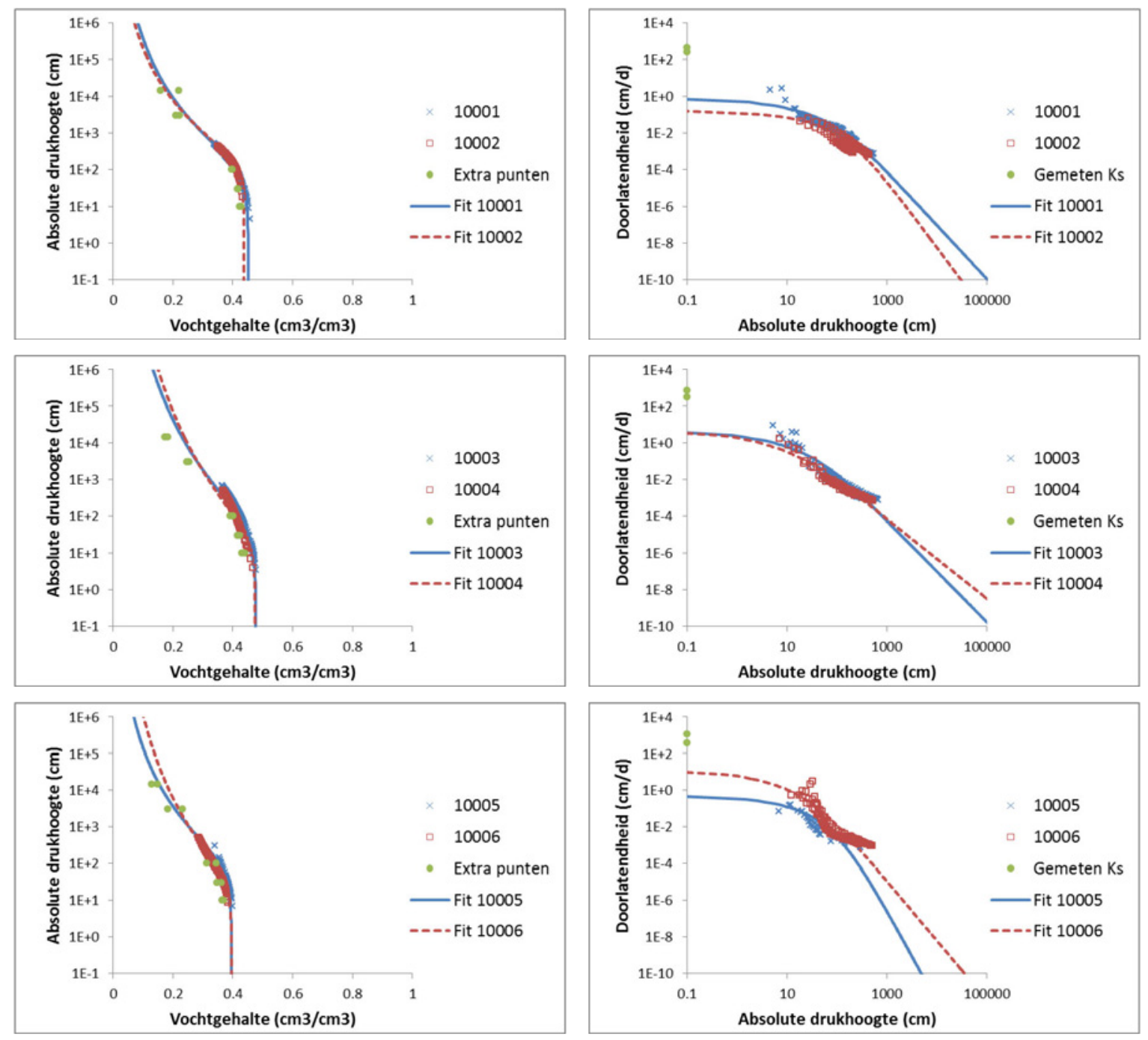

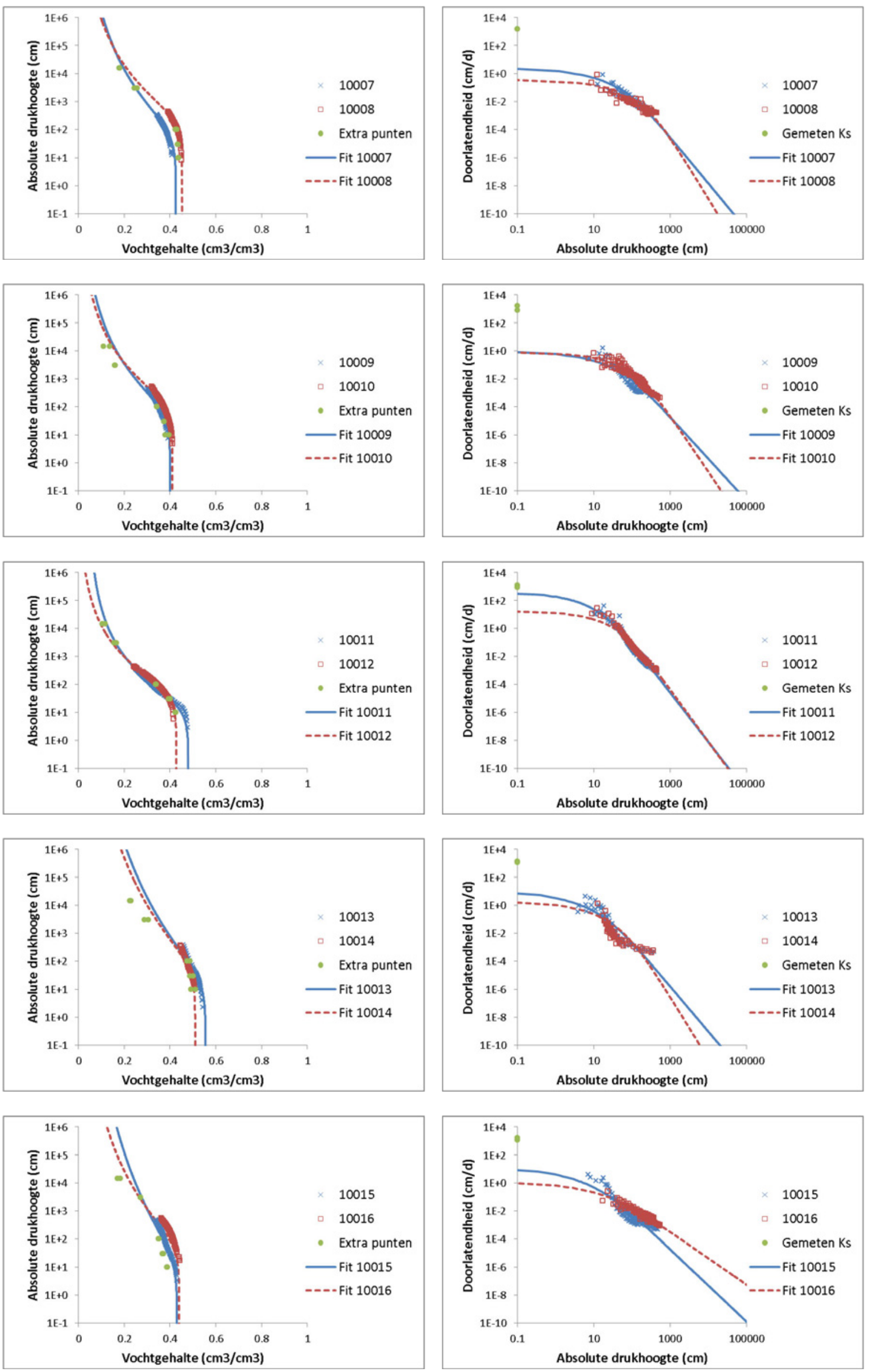

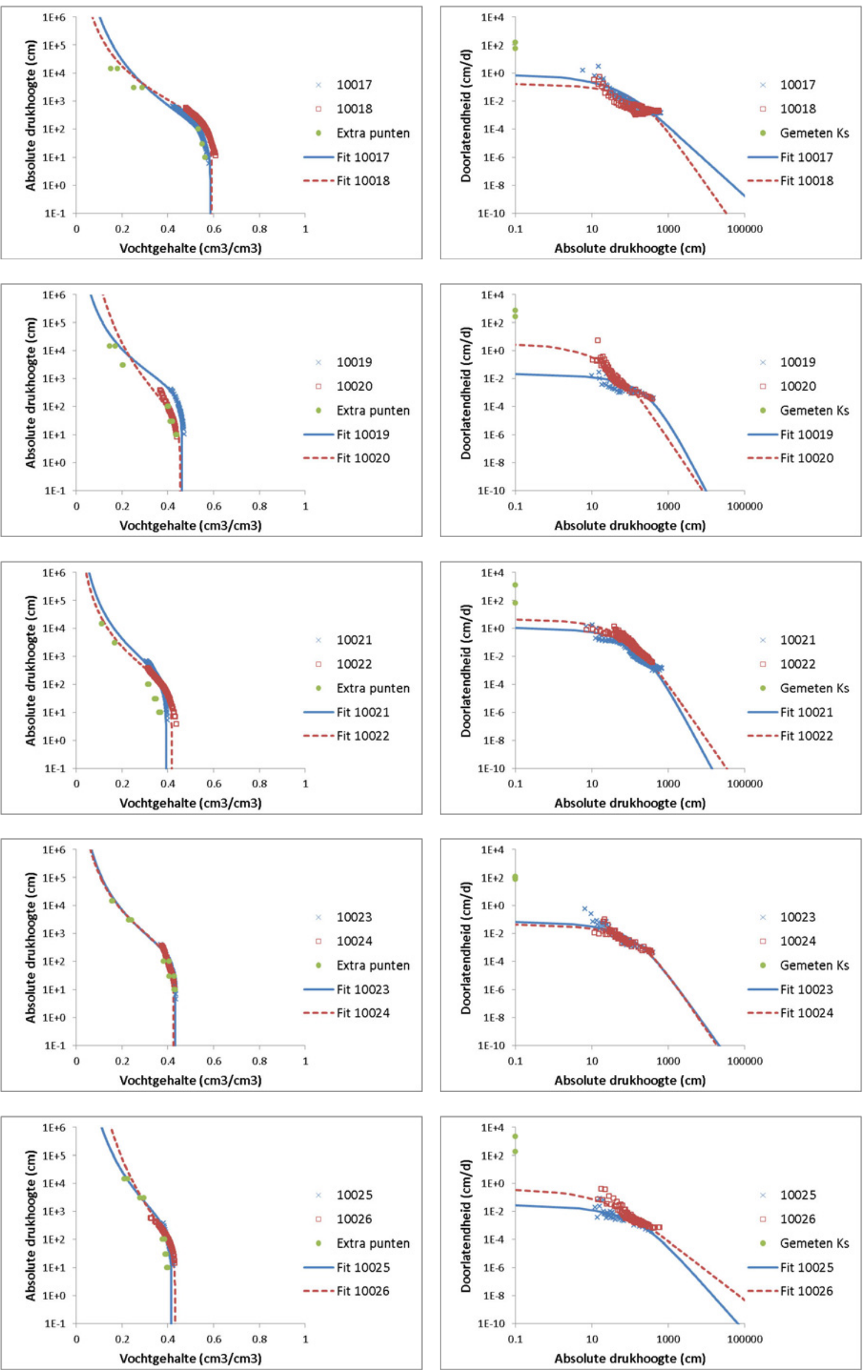

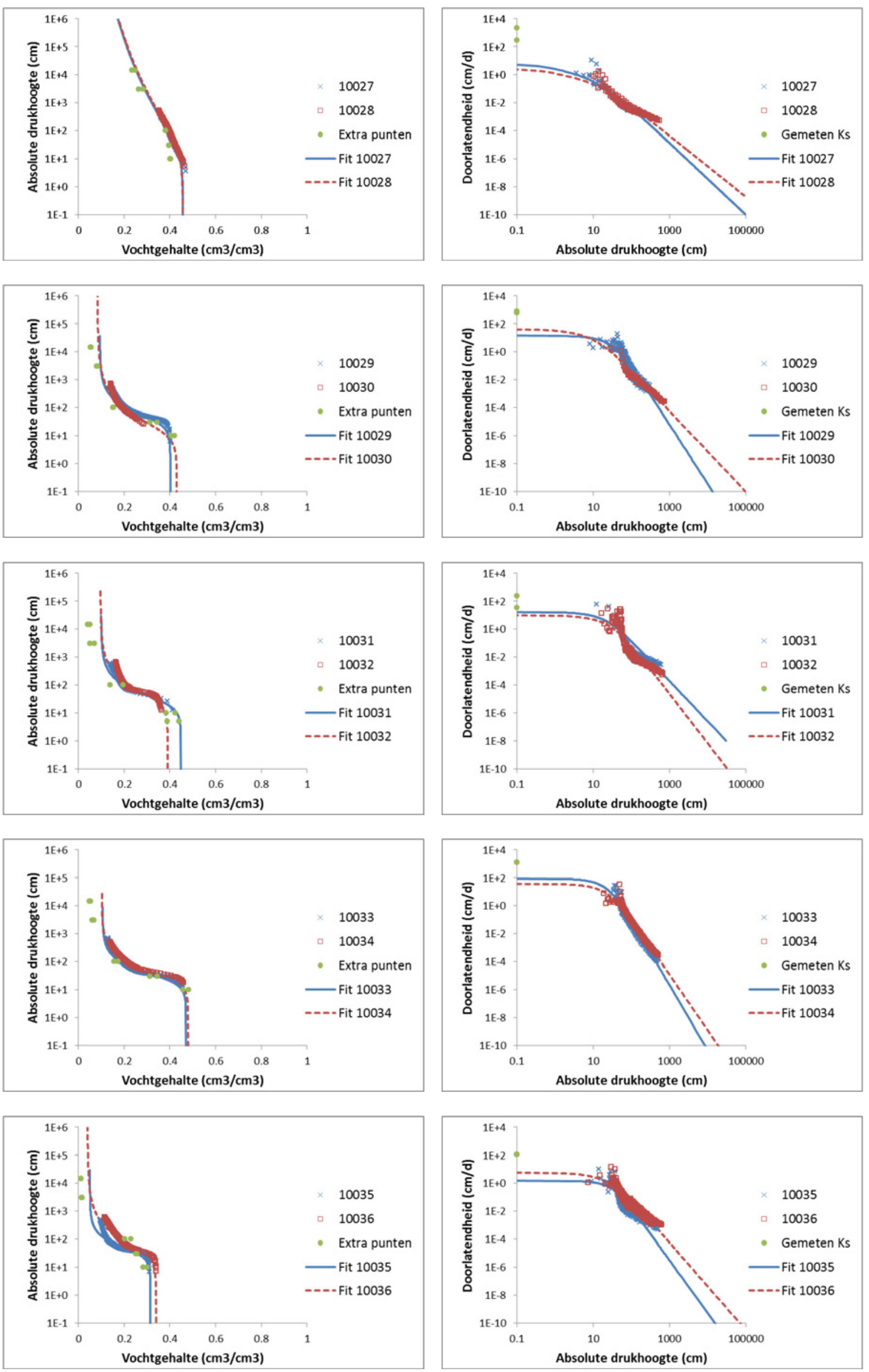

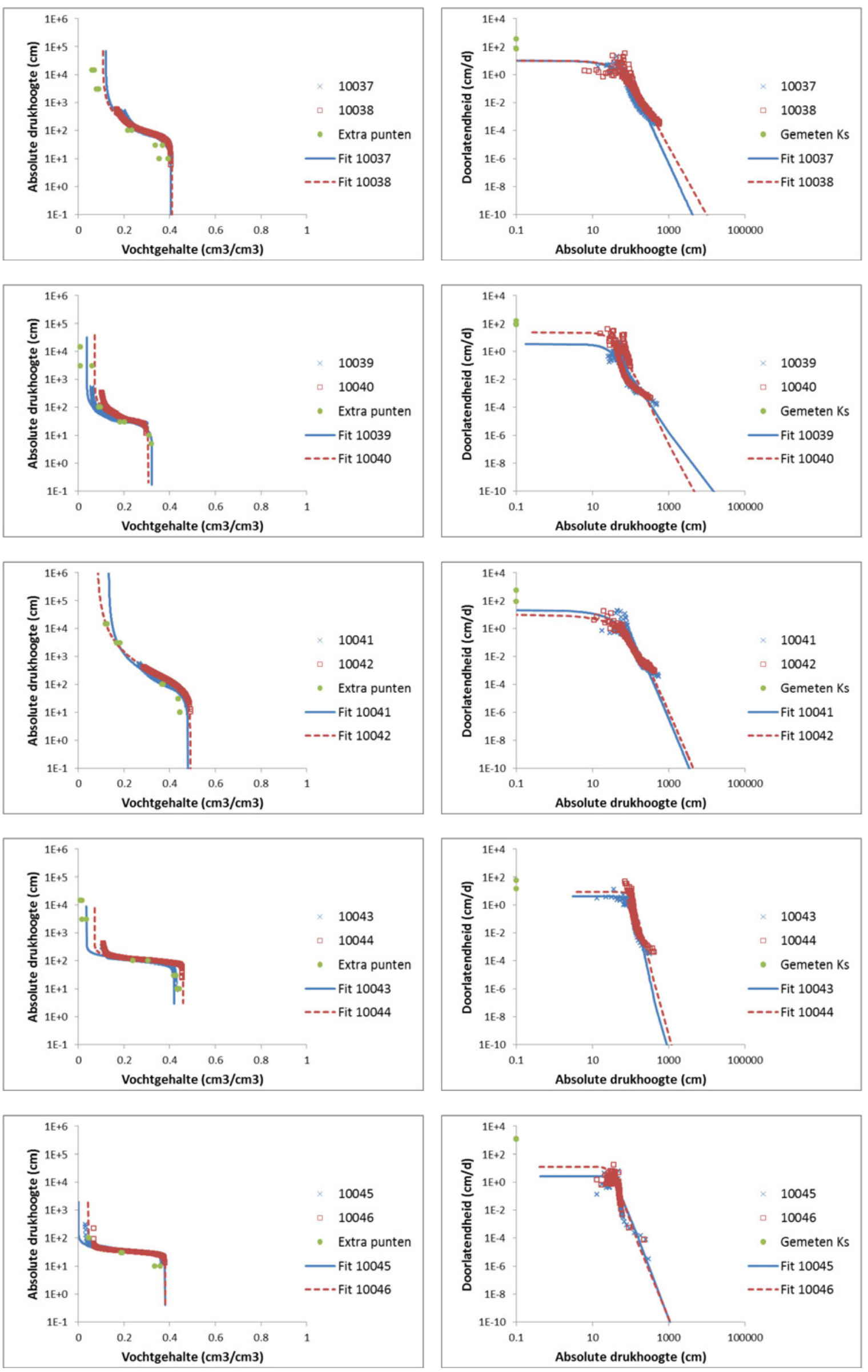

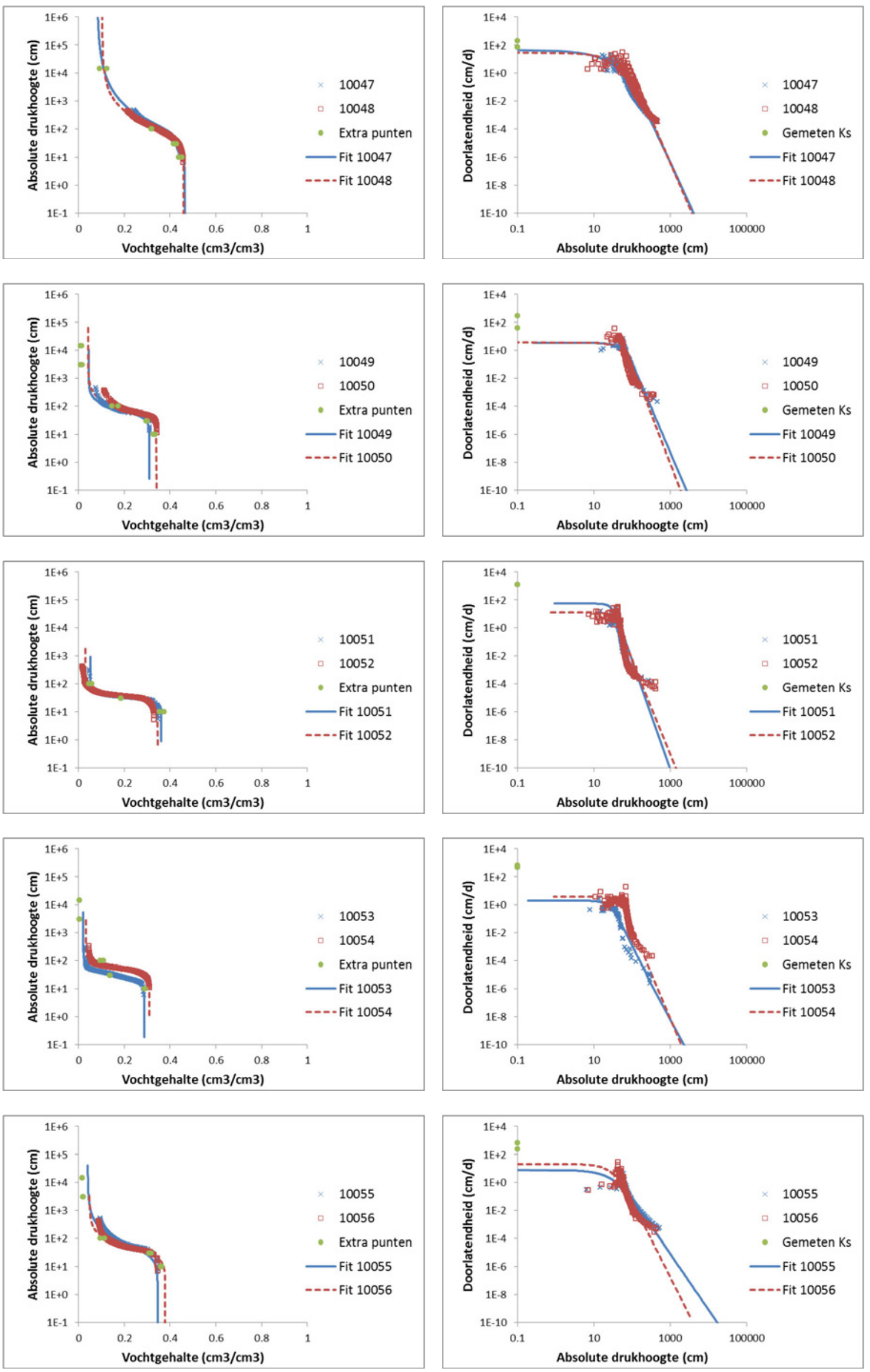

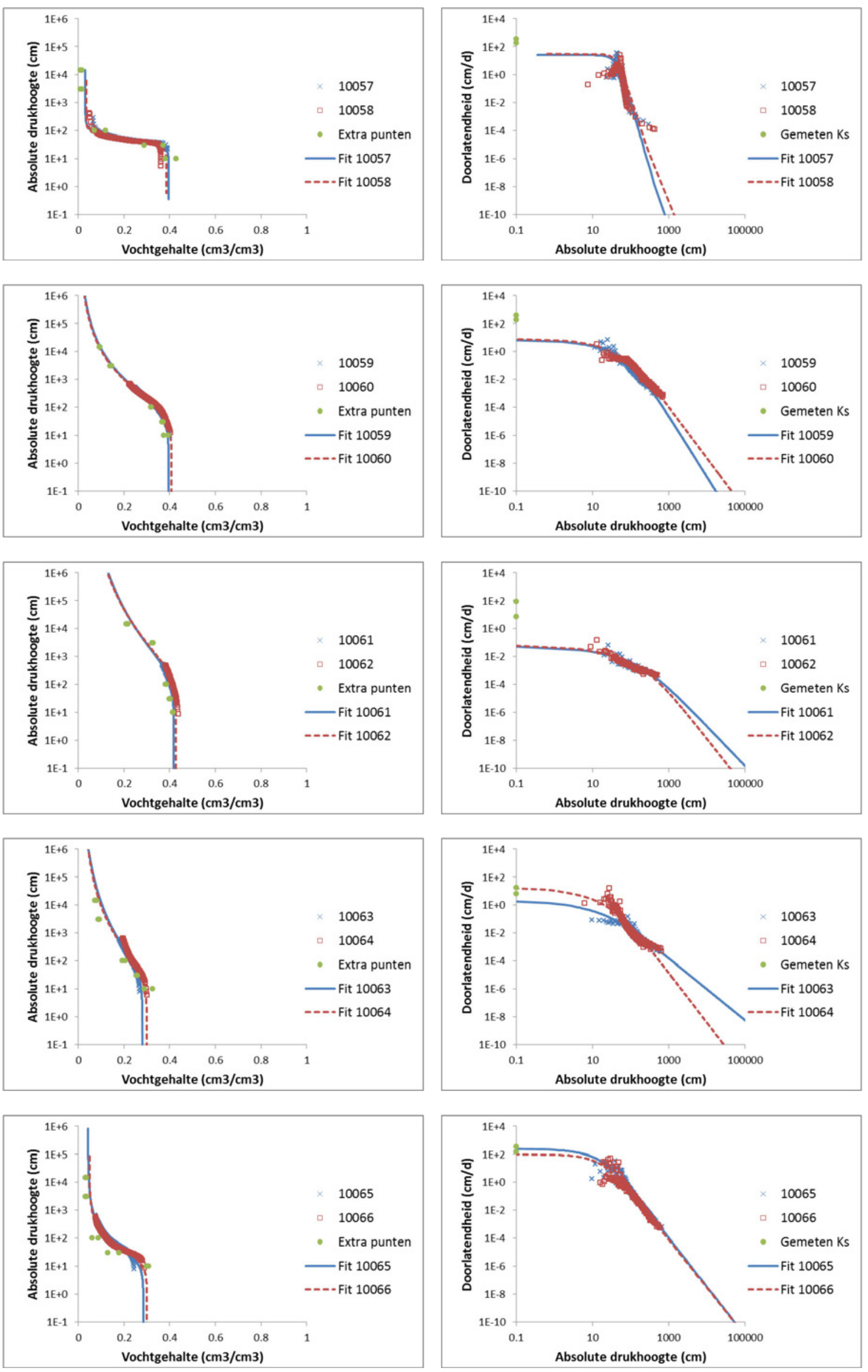

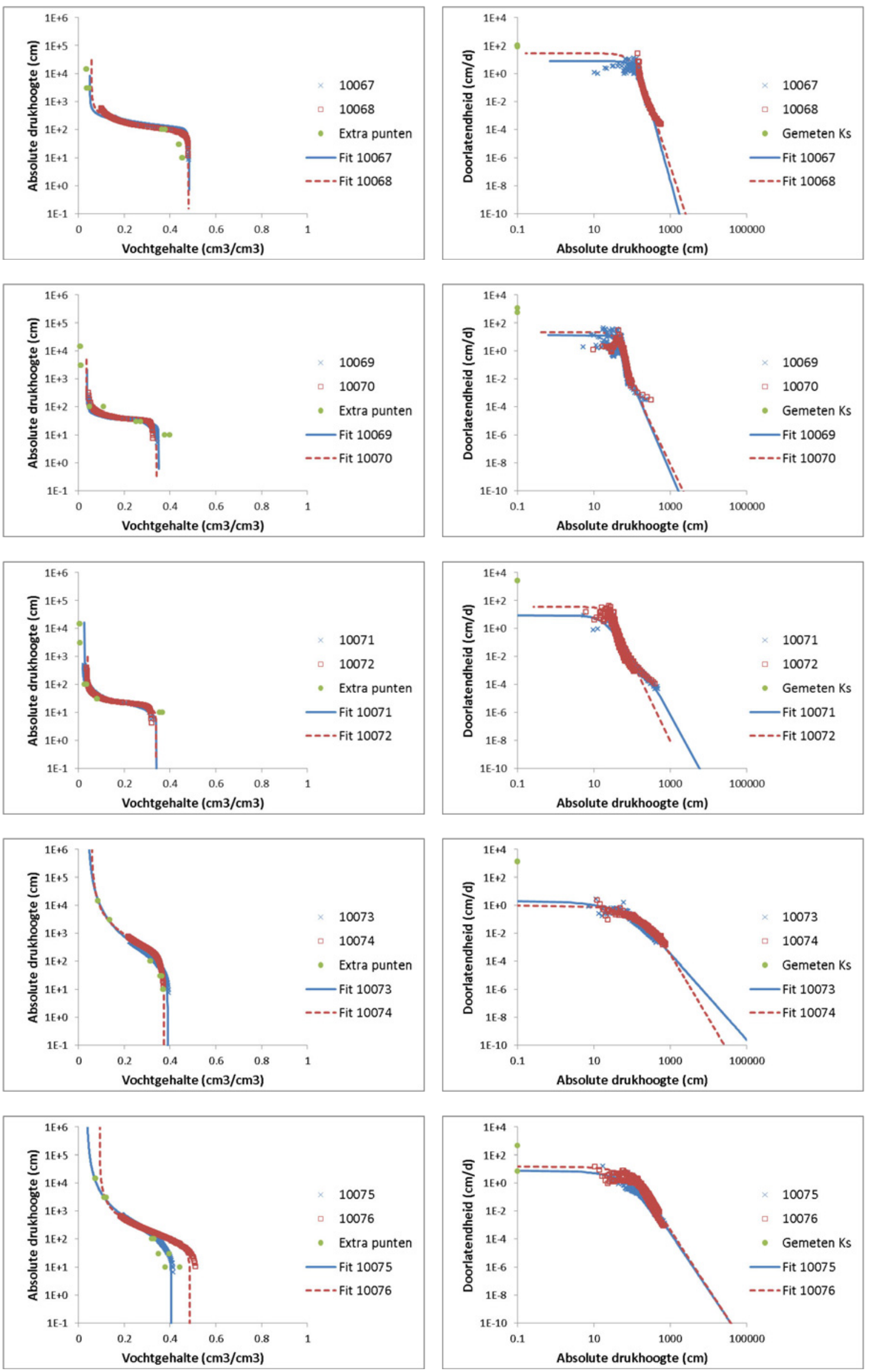

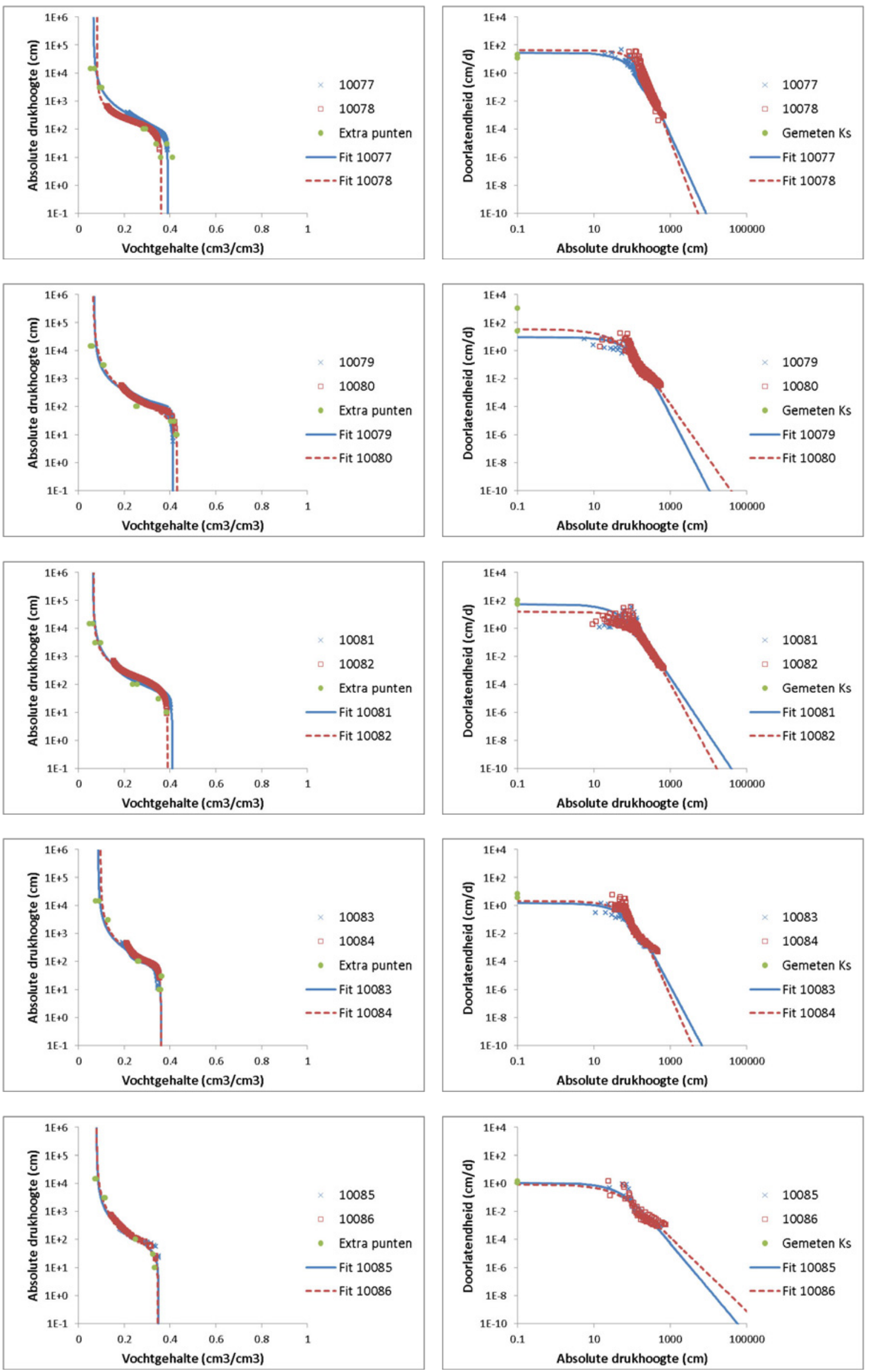

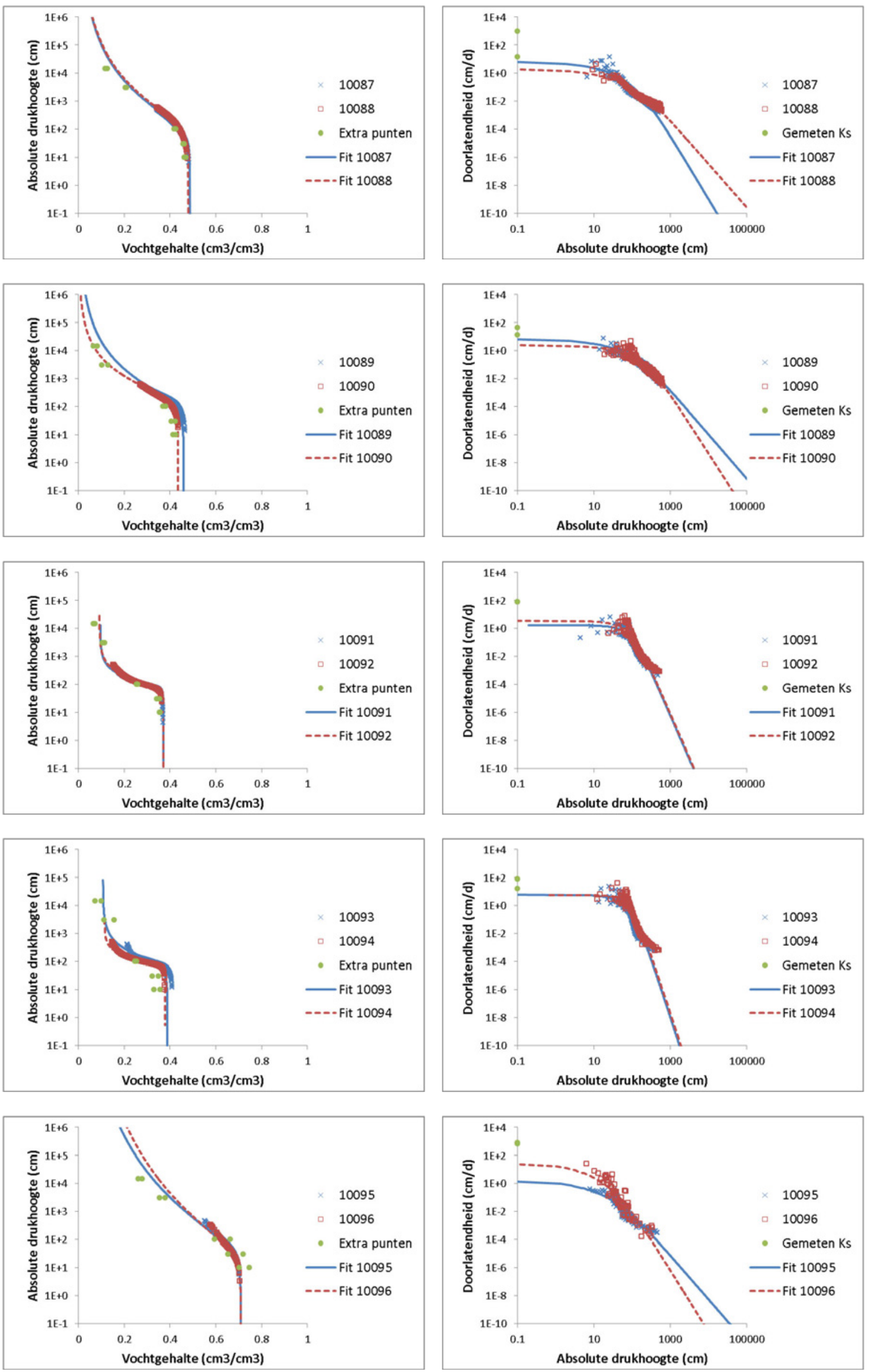

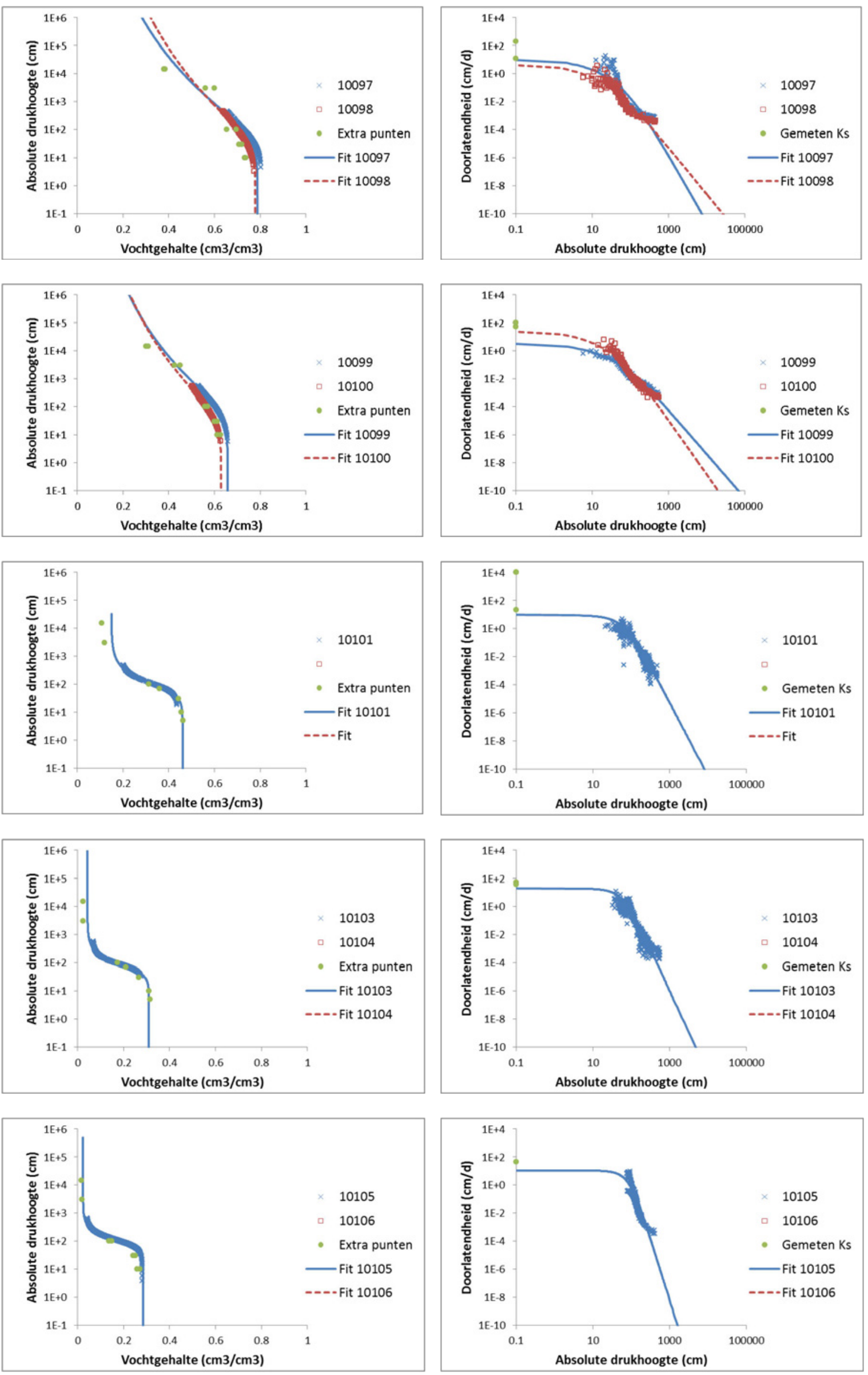

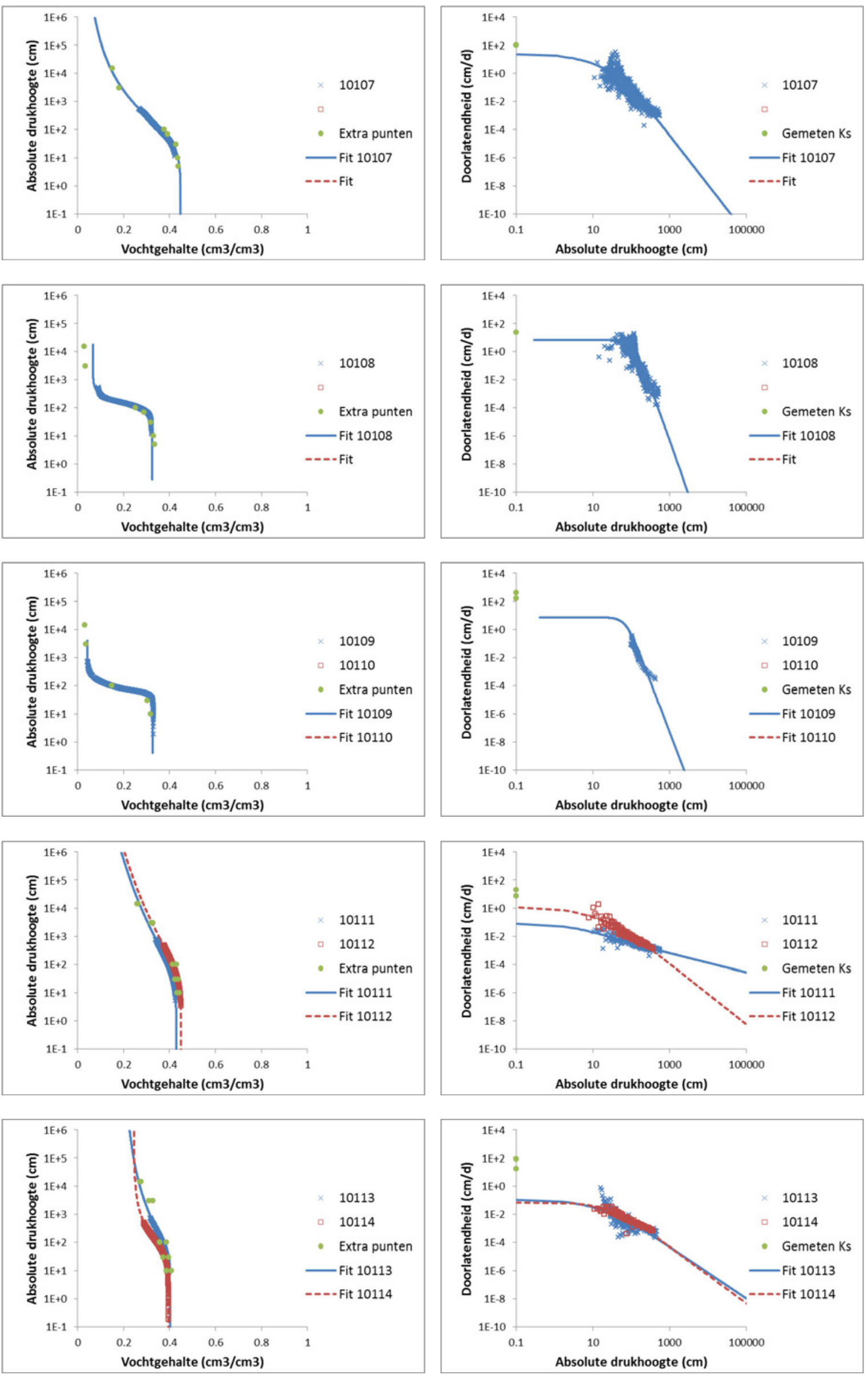

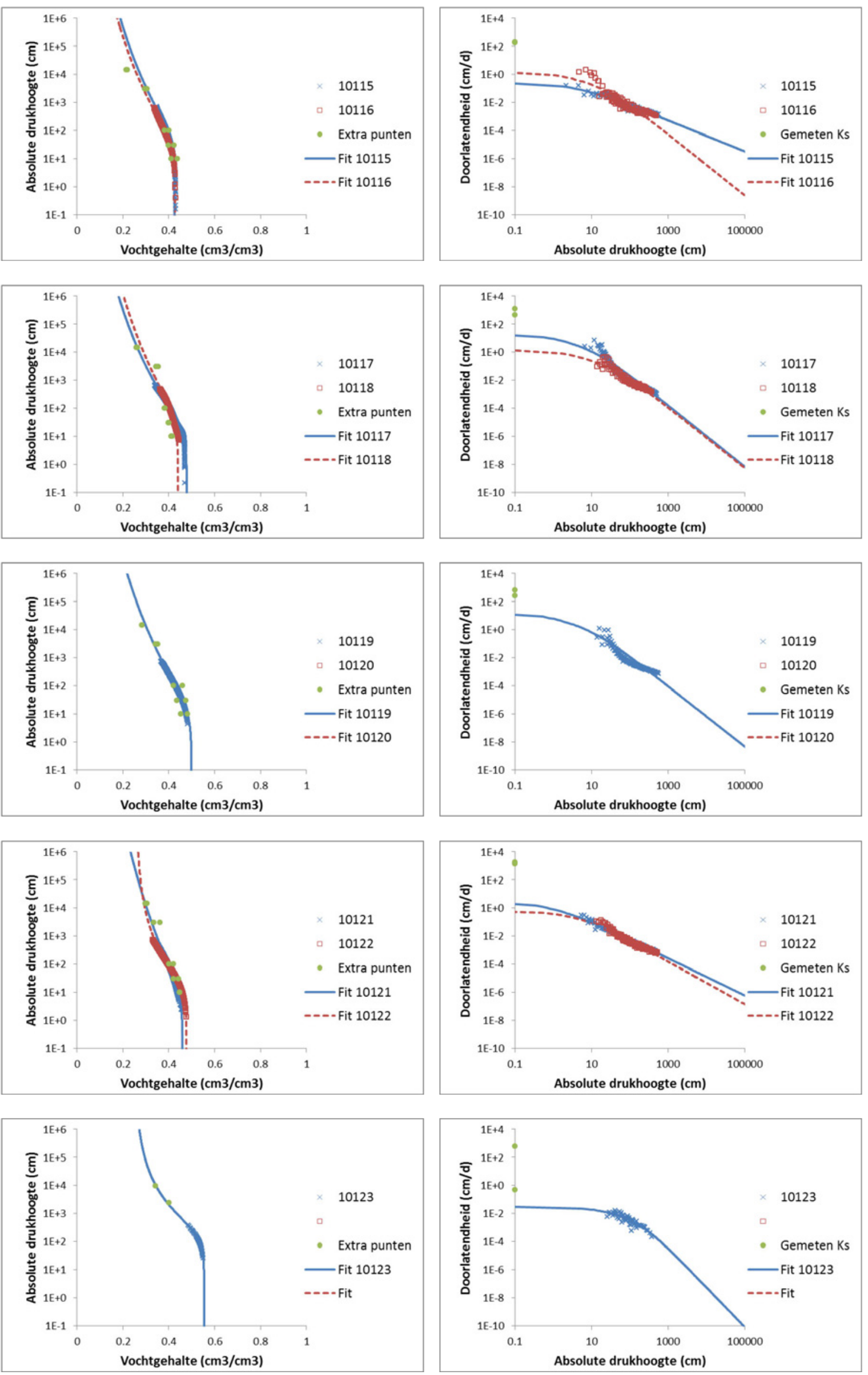

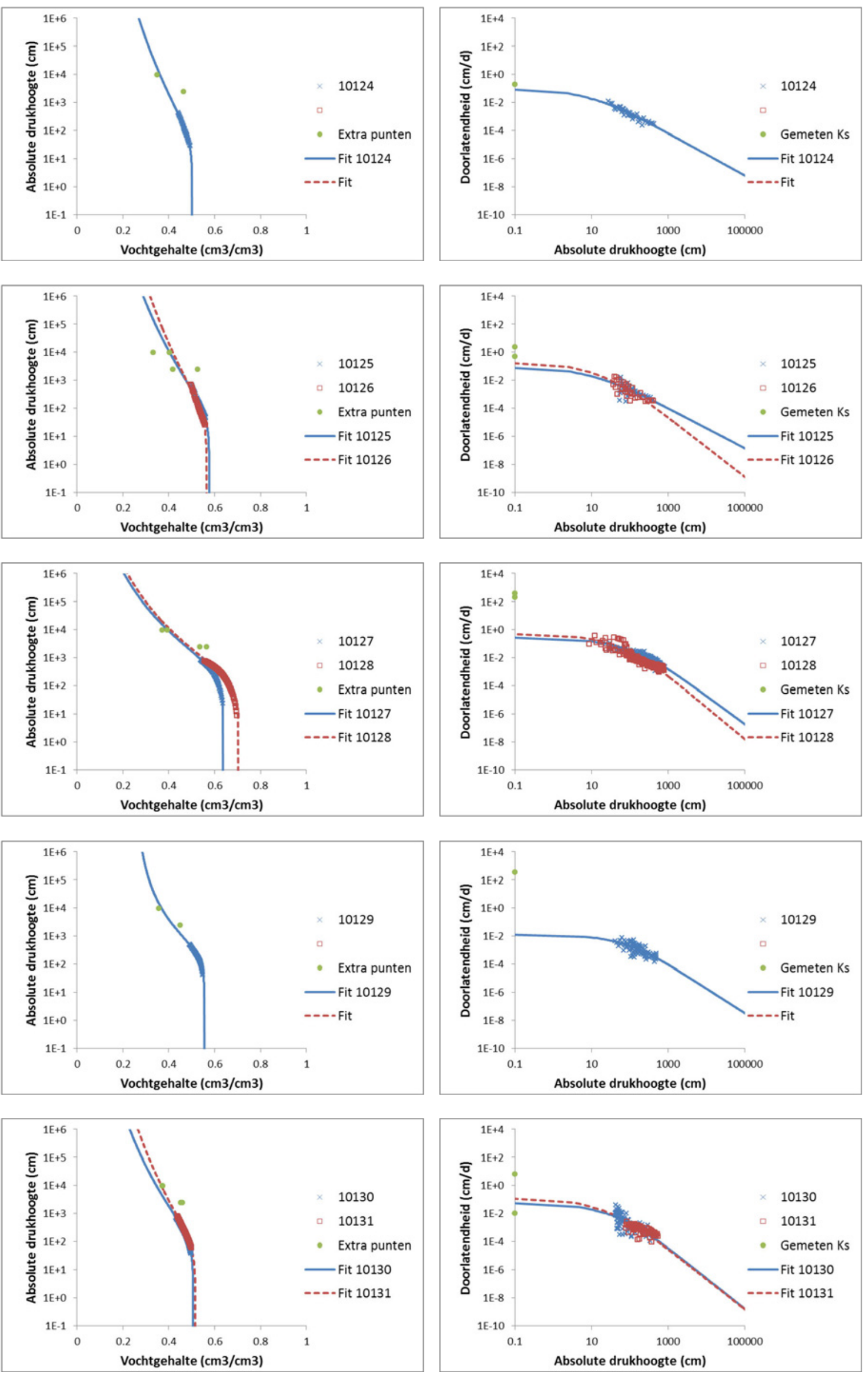

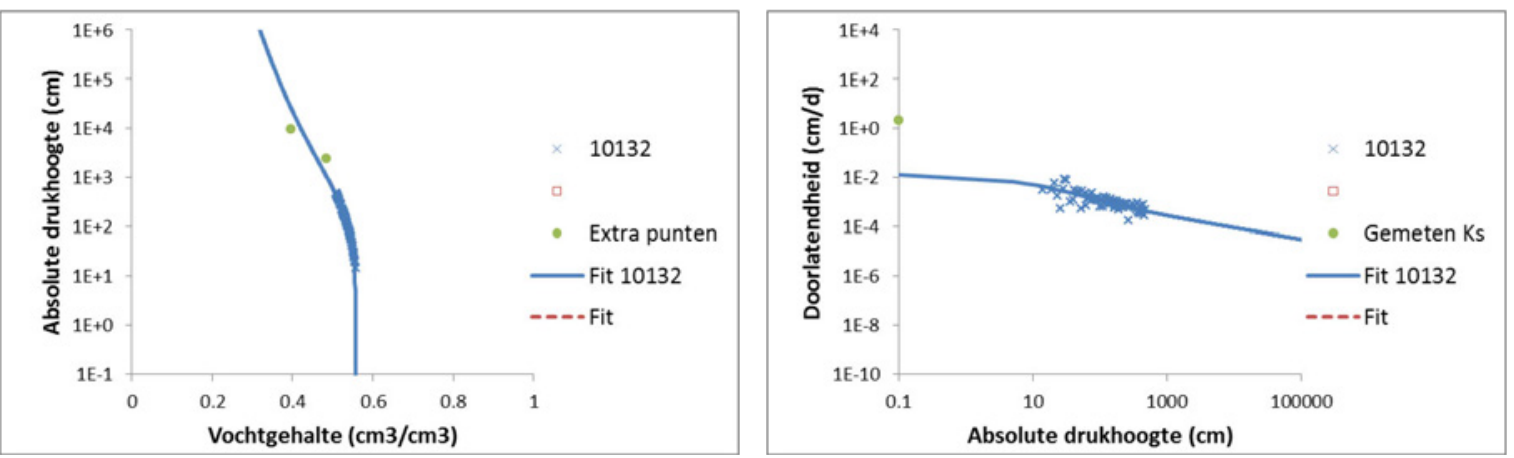


\section{Bijlage 3 Geocodes}

In bodemkarteringen wordt het milieu waarin het materiaal is afgezet of de wijze waarop een bodemhorizont is ontwikkeld, aangeduid met een geocode (soort geologische code, niet geheel synoniem). Deze code wordt vanaf 1984 verplicht aan de onderscheiden bodemhorizonten in bodemkarteringen toegekend. De geocodes zijn in onderstaande tabel weergegeven.

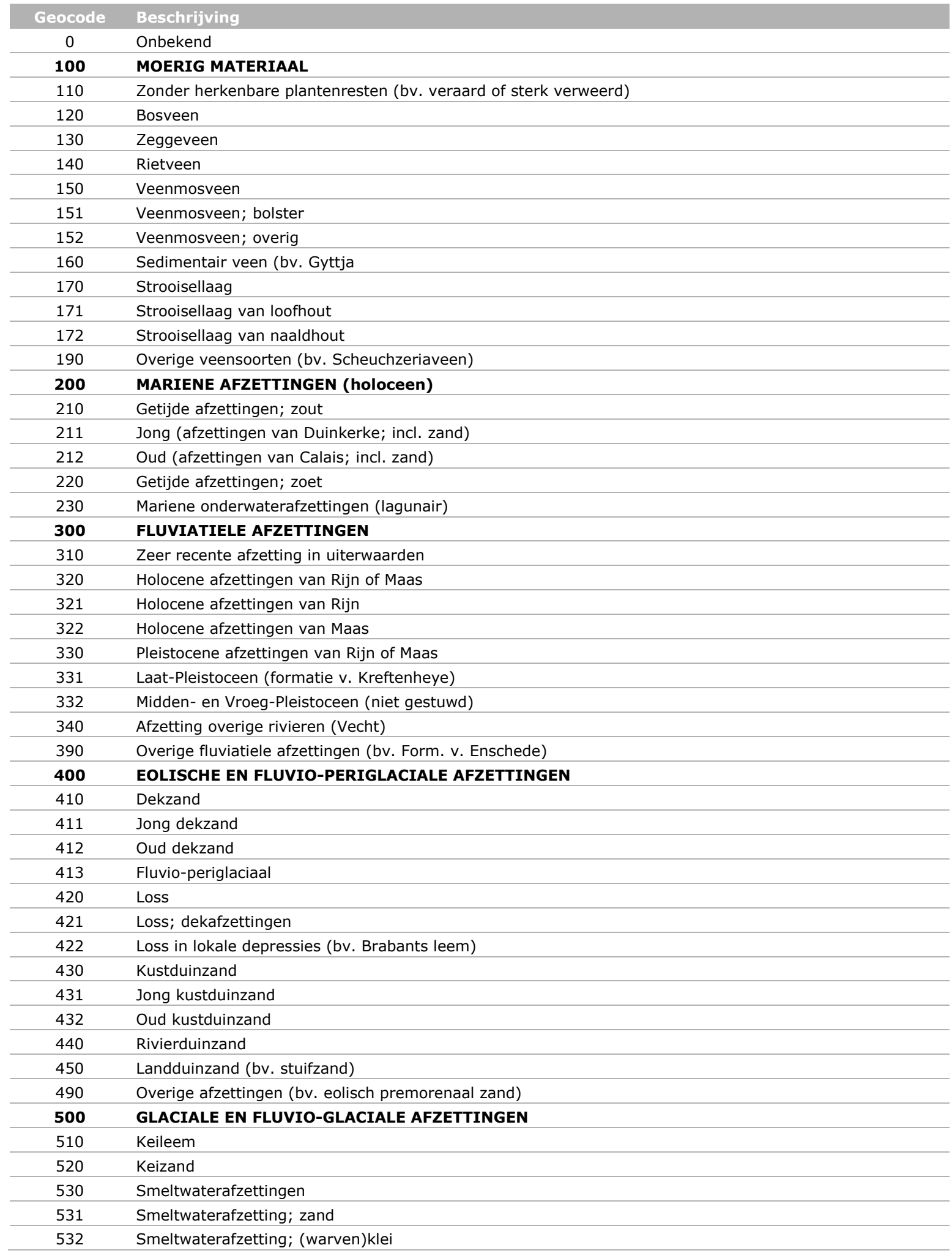




\section{OVERIGE AFZETTINGEN}

610 Hellingafzetting incl. puinwaaierafz. (voor droge dalen)

620 Secundaire loss (bv. colluvium)

630 Gestuwde afzettingen

631 Gestuwde afzettingen van Rijn of Maas

632 Gestuwde afzettingen van oostelijke rivieren

690 Overige

691 Overige geogene afzettingen (bv. kalksteen)

692 Antropogeen homogeen (bv. mestdek)

693 Antropogeen heterogeen (bv. zand + veen)

699 Onbekend 
Wageningen Environmental Research Postbus 47

6700 AA Wageningen

T 0317480700

www.wur.nl/environmental-research

Wageningen Environmental Research

Rapport 2789

ISSN 1566-7197
De missie van Wageningen University \& Research is 'To explore the potential of nature to improve the quality of life'. Binnen Wageningen University \& Research bundelen Wageningen University en gespecialiseerde onderzoeksinstituten van Stichting Wageningen Research hun krachten om bij te dragen aan de oplossing van belangrijke vragen in het domein van gezonde voeding en leefomgeving. Met ongeveer 30 vestigingen, 5.000 medewerkers en 10.000 studenten behoort Wageningen University \& Research wereldwijd tot de aansprekende kennisinstellingen binnen haar domein. De integrale benadering van de vraagstukken en de samenwerking tussen verschillende disciplines vormen het hart van de unieke Wageningen aanpak. 



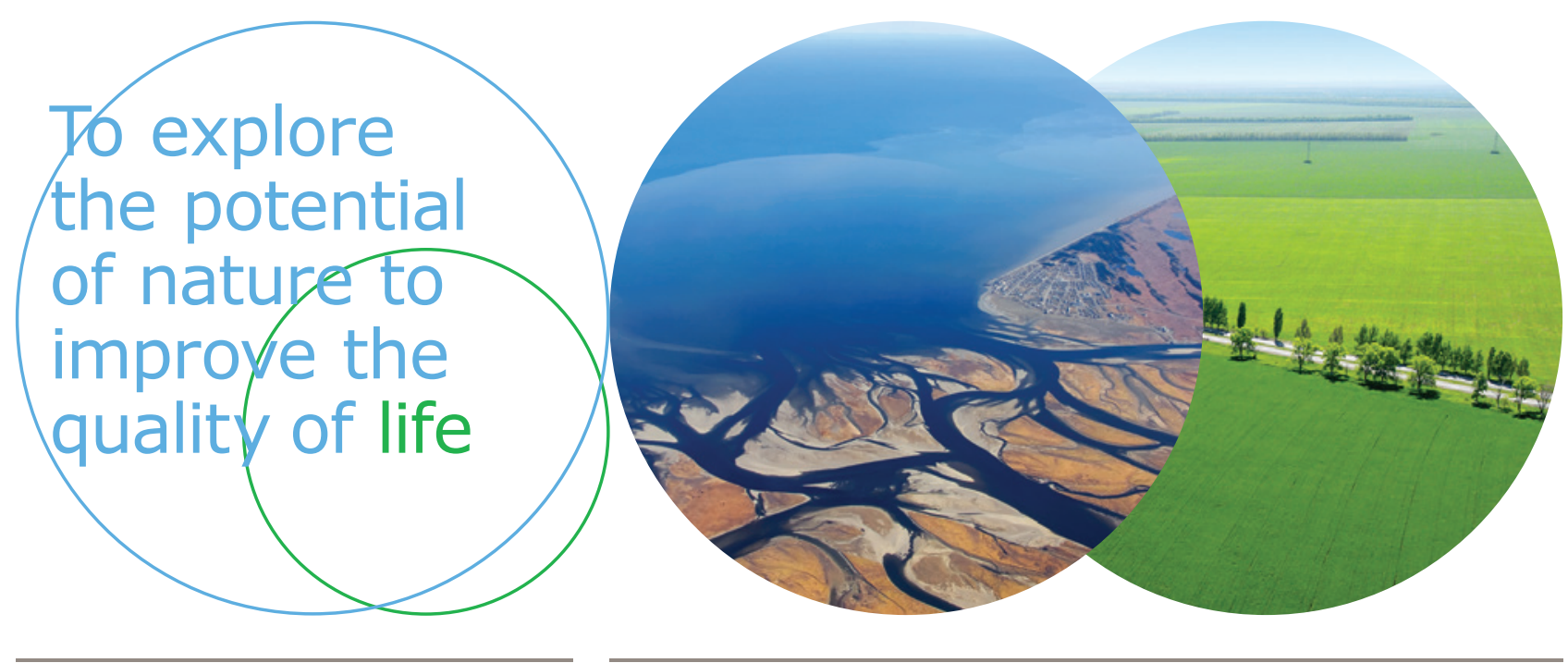

Wageningen Environmental Research Postbus 47

$6700 \mathrm{AB}$ Wageningen

T 317480700

www.wur.nl/environmental-research

Rapport 2789

ISSN 1566-7197
De missie van Wageningen University \& Research is 'To explore the potential of nature to improve the quality of life'. Binnen Wageningen University \& Research bundelen Wageningen University en gespecialiseerde onderzoeksinstituten van Stichting Wageningen Research hun krachten om bij te dragen aan de oplossing van belangrijke vragen in het domein van gezonde voeding en leefomgeving. Met ongeveer 30 vestigingen, 5.000 medewerkers en 10.000 studenten behoort Wageningen University \& Research wereldwijd tot de aansprekende kennisinstellingen binnen haar domein. De integrale benadering van de vraagstukken en de samenwerking tussen verschillende disciplines vormen het hart van de unieke Wageningen aanpak. 